RAQUEL DALL'AGNOL MARTARELLO

PURIFICAÇÃO DE UMA BETA-GALACTOSIDASE PRODUZIDA POR ASPERGILLUS FOETIDUS ATRAVÉS DE TÉCNICAS CROMATOGRÁFICAS 
UNIVERSIDADE DE BRASÍLIA

FACULDADE DE CIÊNCIAS DA SAÚDE

PROGRAMA DE PÓS-GRADUAÇÃO EM CIÊNCIAS DA SAÚDE

RAQUEL DALL'AGNOL MARTARELLO

PURIFICAÇÃO DE UMA BETA-GALACTOSIDASE PRODUZIDA POR ASPERGILLUS FOETIDUS ATRAVÉS DE TÉCNICAS CROMATOGRÁFICAS

Dissertação apresentada como requisito parcial para obtenção do título de Mestre em Ciências da Saúde pelo programa de Pós-Graduação em Ciências da Saúde da Universidade de Brasília.

Orientadora: Profa Dra. Pérola de Oliveira Magalhães Dias Batista

Brasília

2016 


\section{PURIFICAÇÃO DE UMA BETA-GALACTOSIDASE PRODUZIDA POR ASPERGILLUS FOETIDUS ATRAVÉS DE TÉCNICAS CROMATOGRÁFICAS}

Dissertação apresentada como requisito parcial para obtenção do título de Mestre pelo programa de Pós-Graduação em Ciências da Saúde da Universidade de Brasília.

\section{BANCA EXAMINADORA}

Profa. Dra. Pérola de Oliveira Magalhães Dias Batista

Faculdade de Ciências da Saúde da Universidade de Brasília (UNB)

Presidente

Prof. Dr. Francisco de Assis Rocha Neves Universidade de Brasília (UnB)

Profa. Dra. Yanna Karla de Medeiros Nóbrega Universidade de Brasília (UnB)

Profa. Dra. Yris Maria Fonseca-Bazzo

Universidade de Brasilia (UnB) 
Dedico este trabalho à minha família por todo amor e incentivo recebido. Em especial aos meus filhos, portadores de intolerância à lactose. 


\section{AGRADECIMENTOS}

A quem tem a "chave para impedir ou permitir que as coisas aconteçam em minha vida" - DEUS;

A Professora Dra. Pérola, obrigada pela oportunidade, pela orientação e confiança depositada na realização deste trabalho;

Aos meus pais, Severino e Enedina, meus primeiros mestres da escola da vida, obrigada pelo amor, carinho e exemplo. Aos meus irmãos que mesmo à distância, sempre apoiaram minhas decisões;

Ao meu marido Luciano, meu porto seguro, companheiro confidente, obrigada pelo incentivo, apoio, compreensão e paciência. Te amo;

Aos meus filhos, Pedro e Luísa, obrigada pelo brilho do olhar, pelo sorriso que me revigorou nos momentos de desânimo. Com vocês aprendo a ser melhor todos os dias. Perdão meus anjinhos, pelos momentos de ausência. Amo infinitamente!

Aos professores do laboratório Dra. Dâmaris, Dra. Yris e Dr. Maurício obrigada pela atenção e ensinamentos;

Ao professor Dr. Edvaldo Ximenes do Labóratório de Enzimologia e seus alunos, obrigada pela ajuda e troca de conhecimento;

Aos membros da banca de avaliação, minha gratidão por terem aceitado 0 convite e por dispensarem sua atenção e contribuição neste trabalho;

As técnicas do laboratório Patrícia e Michele, obrigada pela amizade e disponibilidade em ajudar;

À colega e amiga Luana, obrigada por todo auxilio neste trabalho. Obrigada por compartilhar conhecimentos, lágrimas, sorrisos, aflições. "Quem tem um amigo tem um anjo". Infinita gratidão;

Aos colegas de bancada do Laboratório de Produtos Naturais: Amanda, Carol, Catarina, Clara, Christian, Dani, Diegue, Ekali, Gabi, Gabriela, Luana, Lorena, 
Marcela, Márcia, Marline, Paula, Renata, Samuel e Yuri, obrigada pela convivência, ajuda, e por terem me acolhido com muito carinho no laboratório;

Ao Dr. Kleber e ao colega Christian obrigada pela ajuda com as análises estatísticas;

As funcionárias da secretaria de pós-graduação em Ciências da Saúde, em especial, Edgrês, pela cordialidade e auxílio prestado ao longo do curso;

À CAPES pela bolsa de mestrado

À FAPDF pelo suporte financeiro através do Edital FAPDF - no 03/2010 Apoio à Projetos - Demanda Espontânea

A todos que de alguma forma contribuíram direta ou indiretamente para a realização deste trabalho, o meu MUITO OBRIGADA! 
"Que história pode ser criada sem lágrima, sem canto, sem livro e sem reza?

Mia Couto

“... todas as coisas cooperam para o bem daqueles que amam a Deus..."

Romanos 8.28 



\section{RESUMO}

A intolerância à lactose é caracterizada pela desordem na absorção do carboidrato lactose, que acomete milhares de pessoas em todo o mundo e está associada à deficiência na produção ou ausência da enzima $\beta$-galactosidase intestinal. Dentro deste contexto, a hidrólise enzimática deste dissacarídeo por $\beta$-galactosidase desempenha papel importante no processamento de produtos lácteos com baixo teor de lactose para o consumo por indivíduos intolerantes. A literatura descreve que, os microrganismos, como fungos filamentosos, são capazes de produzir enzimas de interesse industrial, como por exemplo $\beta$-galctosidases. Desta forma, o objetivo deste trabalho, foi avaliar a produção em meio líquido de $\beta$-galactosidase extracelular por fungos filamentosos isolados do solo do cerrado brasileiro, utilizando resíduos de soja como fonte de carbono. Inicialmente foi realizada uma triagem com 25 linhagens de fungos filamentosos quanto ao potencial de produção de $\beta$ galactosidase. Após a seleção do Aspergillus foetidus, como o melhor fungo produtor, a produção enzimática foi otimizada variando o meio de cultivo e em seguida, realizou-se um planejamento experimental com análise de superfície resposta com as variáveis independentes $\mathrm{pH}$, temperatura e agitação para avaliar a influência destes parâmetros físico-químicos na produção da enzima. A melhor atividade de $\beta$-galactosidase $(26,4 \mathrm{U} / \mathrm{mL})$ foi encontrada no sistema contendo casca de soja $2 \%(\mathrm{p} / \mathrm{v}) \mathrm{em} \mathrm{pH}$ inicial 7,0 a $28^{\circ} \mathrm{C}$ com $120 \mathrm{rpm}$. A curva de indução indicou o $7^{\circ}$ dia de cultivo como o período de melhor atividade. A $\beta$-galactosidase foi parcialmente purificada utilizando cromatografia de gel filtração e troca iônica. A fração mais pura da enzima foi então, caracterizada visando sua aplicação industrial alimentícia e farmacêutica sendo sua atividade máxima a $50^{\circ} \mathrm{C}$ e $\mathrm{pH} 3,0$. A enzima hidrolisou $63 \%$ da lactose presente no leite $\left(\right.$ Molico $\left.^{\circledR}\right)$, e quando testada sua estabilidade em condições de simulação gástrica manteve-se ativa por 2 horas a $37^{\circ} \mathrm{C}$. Estes resultados apontam para a parcial purificação de uma $\beta$-galactosidase ácida e estável de Aspergillus foetidus com potencial aplicação industrial a partir de resíduo de baixo custo.

Palavras-chave: $\beta$-galactosidase; fungos filamentosos; resíduo de soja; Aspergillus foetidus; purificação. 


\begin{abstract}
Lactose intolerance is characterized by a disorder in absorption of the carbohydrate lactose, which affects thousands of people worldwide and is associated with a deficiency or absence of intestinal $\beta$-galactosidase enzyme. In this context, the enzymatic hydrolysis of this disaccharide by $\beta$-galactosidase plays an important role in the processing of dairy products with low lactose content for consumption by intolerant individuals. The literature describes that microorganisms such as filamentous fungi can produce enzymes of industrial interest, such as $\beta$ galactosidases. Thus the objective of this study was to evaluate the production of extracellular $\beta$-galactosidase by filamentous fungi isolated from the soil of the Brazilian savanna in liquid medium using soybean residue as a carbon source. Initially a screening of 25 filamentous fungi strains grown in soybean residue medium was performed assessing $\beta$-galactosidase production potential. After selecting Aspergillus foetidus as the best producer, enzyme production was optimized by varying the culture medium followed by an experimental design with response surface analysis with the independent variables $\mathrm{pH}$, temperature and stirring to assess the influence of these physico-chemical parameters in enzyme production. The best $\beta$-galactosidase activity $(26.4 \mathrm{U} / \mathrm{mL})$ was found in the system containing soybean residues $2 \%(\mathrm{w} / \mathrm{v})$ at initial $\mathrm{pH} 7.0$ at $28^{\circ} \mathrm{C}$ with $120 \mathrm{rpm}$. The induction curve indicated the 7 th culture day as the period of highest activity. $\beta$-galactosidase was half purified using gel filtration and ion exchange chromatography. The purified enzyme was then characterized aiming its food and pharmaceutical industrial uses with maximal activity at $50^{\circ} \mathrm{C}$ and $\mathrm{pH} 3.0$. The enzyme hydrolyzed $63 \%$ of the lactose present in milk (Molico®), and when tested its stability in gastric simulated conditions it remained active for 2 hours at $37^{\circ} \mathrm{C}$. These results demonstrate the half purification of an acidic and stable $\beta$-galactosidase from Aspergillus foetidus with potential industrial application from low-cost residue.
\end{abstract}

Keywords: $\beta$-galactosidase; filamentous fungi; soybean residue; Aspergillus foetidus; purification. 


\section{LISTA DE FIGURAS}

Figura 1 - Rotas de conversão da lactose pela enzima $\beta$-galactosidase $(31,35)$.....26

Figura 2 - Resíduos agroindustriais da soja ………..........................................46

Figura 3 - Esquema das variações dos nutrientes dos meios de cultivo. 49

Figura 4 - Esquema simplificado da metodologia de purificação da $\beta$-galactosidase de Aspergillus foetidus.

Figura 5 - Triagem dos fungos filamentosos isolados do solo do cerrado frente a capacidade de produzir a enzima $\beta$-galactosidase em casca de soja complementado com meio mínimo. Cultivo realizado por 7 dias $120 \mathrm{rpm}$ à $28^{\circ} \mathrm{C}$

Figura 6 - Atividade enzimática de Aspergillus foetidus cultivado (7 dias, 120 rpm, $28^{\circ} \mathrm{C}$ ) em diferentes subprodutos de soja.

Figura 7 - Atividade $\beta$-galactolítica em $A$. foetidus, $P$. felutanum e $P$. variabile, cultivados a $120 \mathrm{rpm}, 28^{\circ} \mathrm{C}$ por 7 dias.

Figura 8 - Eletroforese em gel desnaturante de poliacrilamida do cultivo de A.foetidus em resíduo da soja.

Figura 9 - Avaliação da produção enzimática de $A$. foetidus sob a influência da lactose. .70

Figura 10 - Curva de indução enzimática para o $A$. foetidus cultivado em casca de soja 2\% + meio mínimo (MM1) durante 20 dias.

Figura 11 - Curva de indução enzimática do $A$. foetidus cultivado em casca de soja 2\% + meio mínimo (MM1) de 10 dias em pH 3, 5 e 7.

Figura 12 - Gráfico de pareto para os efeitos das variáveis agitação (X1), temperatura $(\mathrm{X} 2)$ e $\mathrm{pH}(\mathrm{X} 3)$ na atividade de $\beta$-galactosidase.

Figura 13 - Gráfico de superfície resposta para atividade de $\beta$-galactosidase em função das variáveis $\mathrm{X} 2$ (temperatura) e X3 $(\mathrm{pH})$. 
Figura 14 - Perfil cromatográfico da fração concentrada $>30$ em coluna de gel filtração Sephacryl S-200 com tampão fosfato de sódio $0,1 \mathrm{M} \mathrm{pH} 7$ e fluxo de 0,5 $\mathrm{mL} / \mathrm{min}$.

Figura 15 - Perfil cromatográfico da fração concentrada do pico 1 S-200 eluída em coluna de troca iônica do tipo HiTrap DEAE-FF em pH 7,0 com fluxo fixo de 0,250 $\mathrm{ml} /$ min e gradiente de $\mathrm{NaCl}(0-1,0 \mathrm{M})$.

Figura 16 - Perfil eletroforético em gel de poliacrilamida 10\%

Figura 17 - A. Perfil eletroforético em condições desnaturante de gel de poliacrilamida ( SDS-PAGE 10\%).

Figura 18 - Perfil cromatográfico de eluição do Pico 1 DEAE-FF em coluna de gel filtração Sephacryl S-200, utilizando tampão fosfato de sódio $0,1 \mathrm{M} \mathrm{pH} \mathrm{7,0} \mathrm{a} \mathrm{um} \mathrm{fluxo}$ de $0,5 \mathrm{~mL} / \mathrm{min}$.

Figura 19 - Efeito do $\mathrm{pH}$ na atividade de $\beta$-galactosidase do extrato bruto e fração parcialmente purificada de $A$. foetidus.

Figura 20 - Efeito da temperatura na atividade de $\beta$-galactosidase do extrato bruto e fração parcialmente purificada de $A$. foetidus.

Figura 21 - Termoestabilidade da enzima parcialmente purificada nas temperaturas de $4^{\circ} \mathrm{C}, 50^{\circ} \mathrm{C}$ e $70^{\circ} \mathrm{C}$.

Figura 22 - Conversão da lactose em glicose em diferentes concentrações de enzima.

Figura 23 - Efeito in vitro da enzima $\beta$-galactosidase em simulação das condições gástricas 


\section{LISTA DE TABELAS}

Tabela 1 - Principais alimentos que contém lactose .25

Tabela 2 - Preparações comerciais de $\beta$-galactosidase de diferentes fontes microbianas 29

Tabela 3 - Fungos filamentosos isolados do solo do bioma cerrado centro-oeste brasileiro, utilizados neste trabalho

Tabela 4 - Níveis e valores das variáveis independentes do processo experimental para o estudo da produção $\beta$-galactosidase sob influência de diferentes valores de $\mathrm{pH}$, temperatura e agitação.

Tabela 5 - Matriz do planejamento fatorial $2^{3}$ com ponto central em triplicata para produção de $\beta$ - galactosidase

Tabela 6 - Resultado do planejamento fatorial $2^{3}$ para análise da influência das variáveis (agitação, temperatura e pH) frente a produção de $\beta$ - galactosidase .75

Tabela 7 - Analise de variância (ANOVA) para o modelo de segunda ordem para otimização da produção de $\beta$-galactosidase. Incluindo as variáveis independentes: Agitação (X1), Temperatura (X2) e pH (X3) ...

Tabela 8 - Descrição da atividade enzimática de $\beta$-galactosidase e proteína obtida nas etapas de ultrafiltração por membranas de 100 kDa e 30 kDa.

Tabela 9 - Resumo das etapas de purificação de $\beta$-galactosidase produzida por $A$. foetidus cultivado em casca de soja como fonte de carbono

Tabela 10 - Efeito de íons metálicos e EDTA na atividade da $\beta$-galactosidase parcialmente purificada de $A$. foetidus a partir do cultivo submerso com casca de soja .90

Tabela 11 - Especificidade do substrato da $\beta$-galactosidase parcialmente purificada do Aspergillus foetidus. 


$\begin{array}{ll}\text { ANOVA } & \text { Análise de variância } \\ \text { CMC } & \text { Carboximetil celulose } \\ \text { DEAE } & \text { Dietiaminoetil } \\ \text { DNS } & \text { Ácido 3,5-dinitrosalicílico } \\ \text { EB } & \text { Extrato Bruto } \\ \text { EDTA } & \text { Ácido etilenodiamino tetra-acético } \\ \text { GOS } & \text { Galacto-oligossacarideo } \\ \text { GRAS } & \text { Generally recognized as safe } \\ \text { HMW } & \text { Alto peso molecular } \\ \text { Da } & \text { Daltons } \\ \text { Km } & \text { Constante de Michaelis-Menten } \\ \text { ONPG } & \text { Ortho-nitro-fenol- } \beta \text {-D- galactoiranosídeo } \\ \text { pH } & \text { Potencial Hidrogeniônico } \\ \text { pNPG } & \text { Para-Nitrofenil- } \beta \text {-D-glicopiranosídeo } \\ \text { rpm } & \text { Rotação por minuto } \\ \text { SDS } & \text { Dodecil-sulfato de sódio } \\ \text { SDS- PAGE } & \text { Dodecil-sulfato de sódio poliacrilamida } \\ \text { S-200 } & \text { Sephacryl } \\ \text { SGF } & \text { Fluído Gástrico Simulado } \\ \text { TCA } & \text { Ácido tricloroacético } \\ \text { TEMED } & \text { Tetrametiletilenodiamina } \\ \text { UI } & \text { Unidade Internacional } \\ \text { Vmáx } & \text { Velocidade máxima da reação } \\ \text { X-Gal } & \text { 5-Bromo-4-cloro-indoil- } \beta \text {-D-galactopiranosideo }\end{array}$




\section{SUMÁRIO}

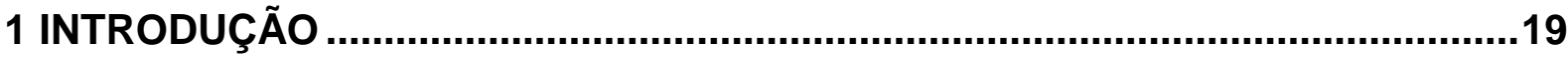

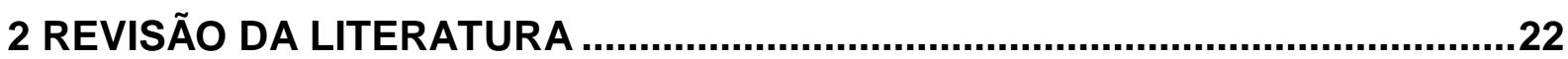

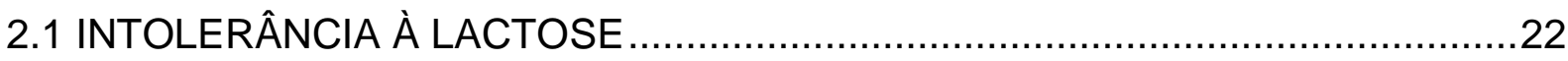

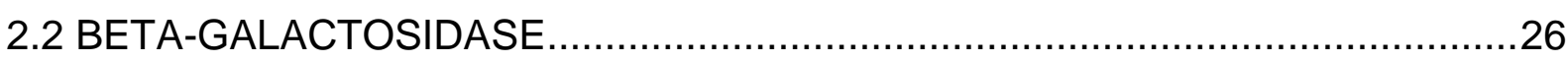

2.3 APLICABILIDADE DA BETA-GALACTOSIDASE NA INDÚSTRIA ALIMENTÍCIA

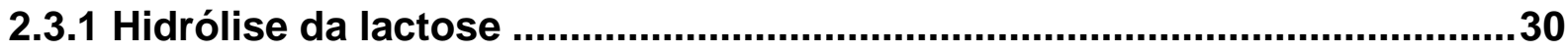

2.3.2 Síntese de galacto-oligossacarídeos (GOS) .........................................32

2.4 APLICABILIDADE NA INDÚSTRIA FARMACÊUTICA ......................................33

2.5 FUNGOS FILAMENTOSOS DO SOLO CERRADO BRASILEIRO …..................35

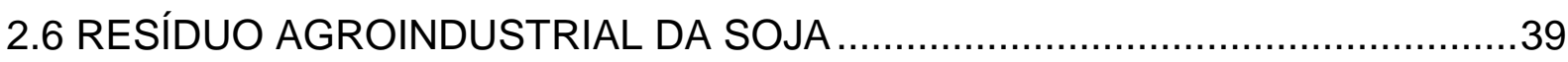

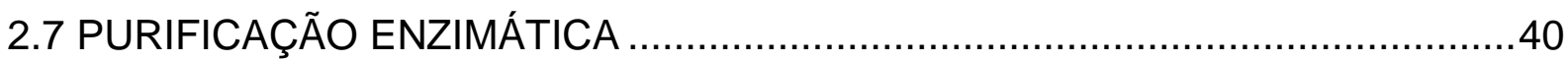

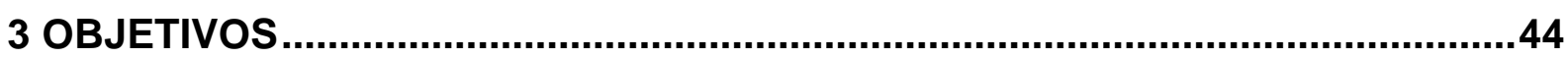

4 MATERIAIS E MÉTODOS

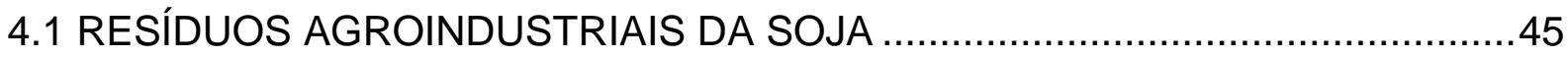

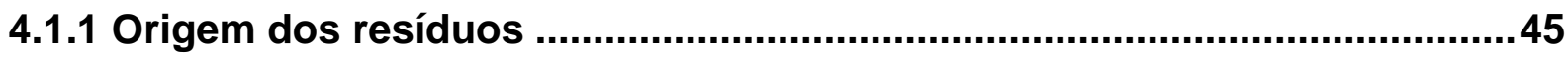

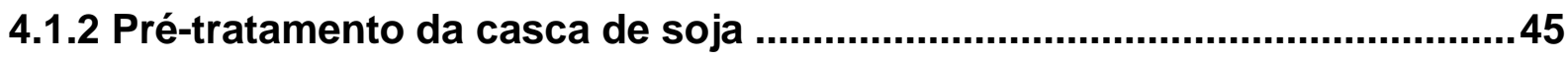

4.1.3 Obtenção do extrato líquido da soja (leite de soja) e okara .......................45

4.2 ORIGEM E MANUTENÇÃO DOS FUNGOS FILAMENTOSOS ….....................46

4.3 CONDIÇÕES DE CULTIVO DOS FUNGOS FILAMENTOSOS ….....................47

4.3.1 Meio de cultivo utilizado para triagem ….................................................47 
4.3.3 Preparo do inóculo

4.4 DETERMINAÇÃO DA ATIVIDADE ENZIMÁTICA .....................................50

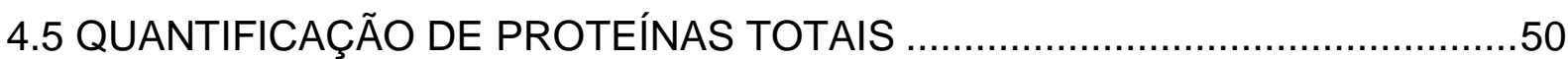

4.6 CURVA DE INDUÇÃO ENZIMÁTICA ................................................... 51

4.7 DELINEAMENTO EXPERIMENTAL - INFLUÊNCIA DA AGITAÇÃO, PH E

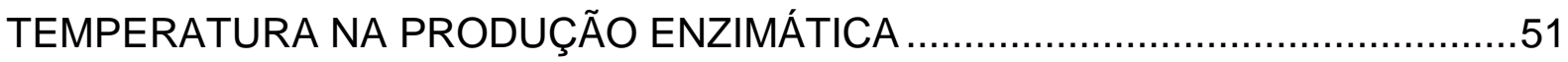

4.8 PURIFICAÇÃO DA BETA-GALACTOSIDASE ....................................... 53

4.8.1 Ultrafiltração ..................................................................................53

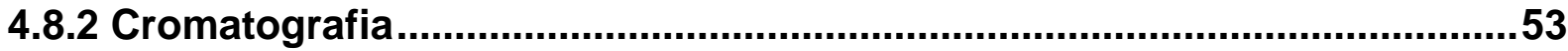

4.8.2.1 Cromatografia de gel filtração - Sephacryl S-200 HR ............................................. 53

4.8.2.2 Cromatografia de troca iônica - DEAE FF................................................... 54

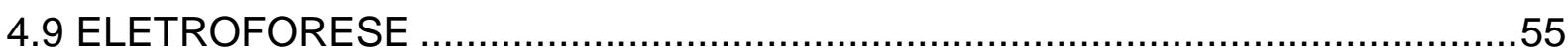

4.9.1 Eletroforese em gel de poliacrilamida (SDS-PAGE) ..............................55

4.9.1.1 Coloração com azul de Comassie .................................................................... 56

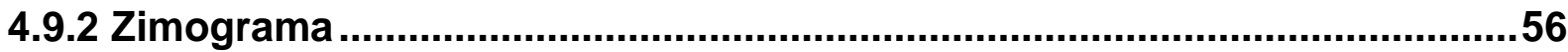

4.9.3 Determinação da massa molar.................................................................57

4.10 CARACTERIZAÇÃO BIOQUÍMICA DA BETA-GALACTOSIDASE 57

4.10.1 Efeito do pH.

4.10.2 Efeito da temperatura .58

4.10.3 Termoestabilidade. 58 
4.10.6 Determinação de parâmetros cinéticos.......................................................59

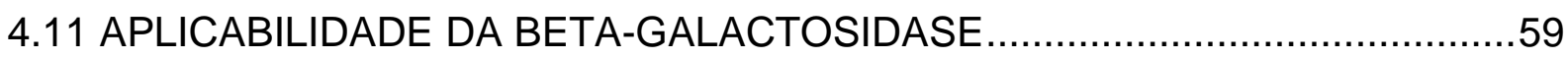

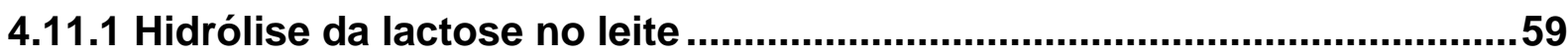

4.11.2 Estabilidade da enzima em condições de simulação gástrica.................60

5 RESULTADOS E DISCUSSÃO .62

5.1 SELEÇÃO DE FUNGOS FILAMENTOSOS PRODUTORES DE BETA-

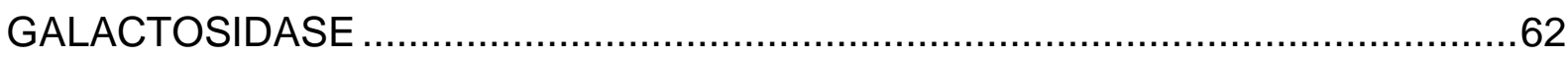

5.2 AVALIAÇÃO DA PRODUÇÃO DE BETA-GALACTOSIDASE............................64

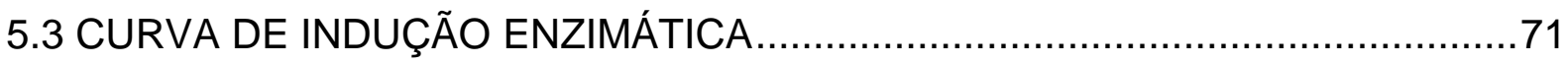

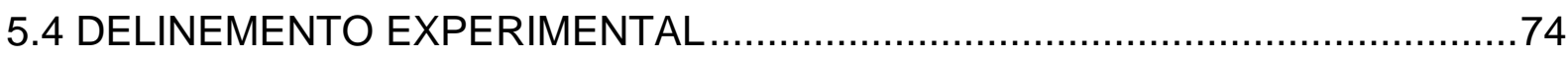

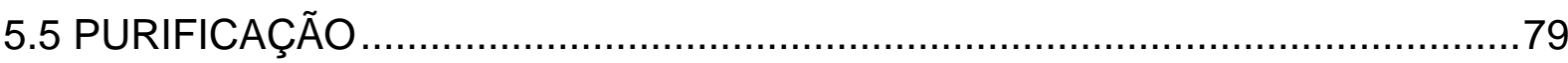

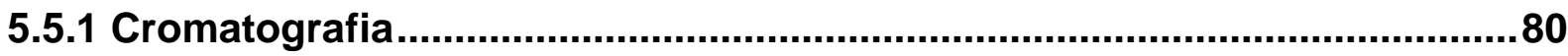

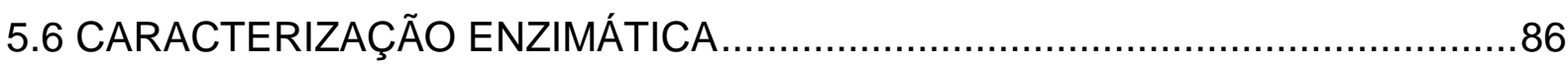

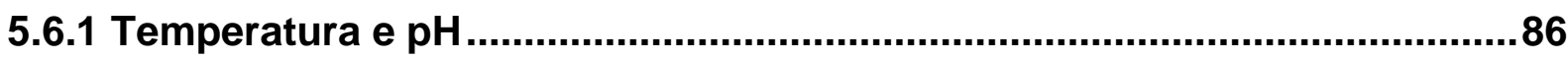

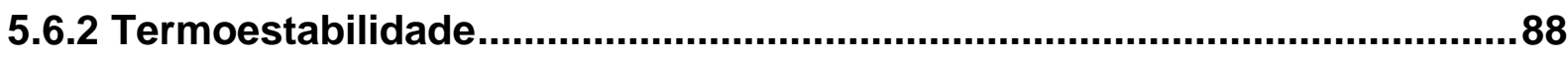

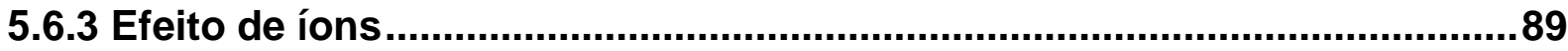

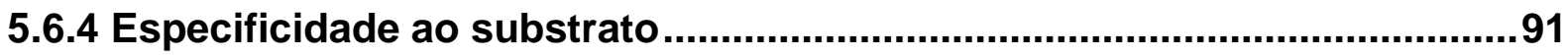

5.6.5 Parâmetros cinéticos Km e Vmáx..............................................................92 


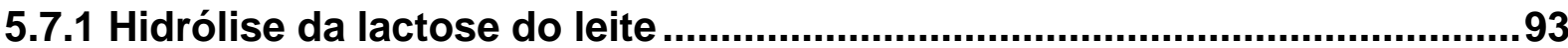

5.7.2 Simulação da $\beta$-galactosidase em pH gástrico .........................................94

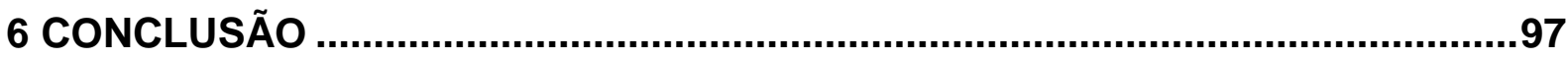

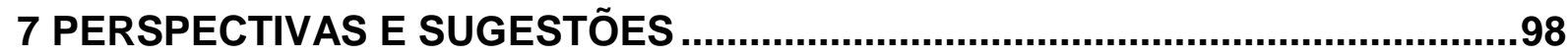

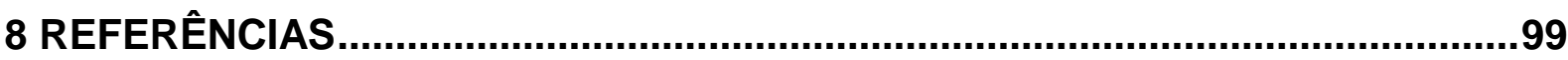




\section{INTRODUÇÃO}

A incapacidade parcial ou completa em digerir a lactose nos seres humanos é manifestada por uma síndrome clínica denominada intolerância a lactose (1). Essa síndrome é caracterizada pela deficiência da enzima $\beta$-galactosidase intestinal sendo uma das deficiências enzimáticas mais comuns, acometendo grande parte da população mundial com prevalência em latino-americanos e asiáticos (2-4).

A lactose é um dissacarídeo, presente no leite materno e na maioria do leite dos mamíferos, que ao ser ingerido, para ser absorvido necessita ser hidrolisado em moléculas menores - glicose e galactose. Na ausência ou deficiência da enzima $\beta$ galactosidase entérica, a lactose não absorvida provoca irritação na mucosa causando desconforto intestinal que vai desde diarreia e dor abdominal à desnutrição grave (1). O tratamento consiste principalmente em evitar alimentos contendo lactose. No entanto dietas com esta restrição podem acarretar deficiências nutricionais, uma vez que, esses produtos fornecem nurientes essenciais como cálcio $(75 \%)$, vitamina $A$ e $D$ e fósforo, aumentando o risco de fraturas e doenças como a osteoporose $(1,2)$.

Uma alternativa para esses pacientes é a ingesta de produtos com a lactose já hidrolisada. A hidrólise enzimática da lactose vem sendo muito utilizada pelas indústrias de laticínios para melhorar a digestibilidade do leite e derivados, proporcionando efeitos benéficos sobre a assimilação desses alimentos por indivíduos intolerantes $(5,6)$. Outra alternativa, é a ingestão da enzima $\beta$ galactosidase como suplemento alimentar em preparações farmacêuticas, no qual o desafio é encontrar $\beta$-galactosidases com características adequadas para a hidrólise in vivo (7).

A hidrólise enzimática de produtos lácteos, somado aos efeitos benéficos para intolerantes, também favorece a indústria alimentícia de doces e sorvetes. A lactose por ter baixo poder adoçante e ser pouco solúvel, pode causar cristalização e problemas tecnológicos e sensoriais de arenosidade no processamento de produtos lácteos $(8,9)$. 
Além de reações de hidrólise, as $\beta$-galactosidases também podem catalisar reações de transgalactosilação produzindo galacto-oligossacarídeos (GOS). Atualmente os galacto-oligossacarídeos - carboidratos não digeríveis de baixa caloria - têm atraído especial interesse na indústria alimentícia, devido suas propriedades prebióticas funcionais reconhecidas (10).

A maioria das $\beta$-galactosidases utilizadas nos processos industriais são de origem microbiana, sendo produzidas por bactérias, leveduras e fungos filamentosos. Os fungos filamentosos destacam-se por serem microrganismos de fácil adaptação, colonizando diferentes ambientes e produzindo diversos metabólitos de interesse biológico (11-13). Somado a isso, os fungos na sua grande maioria expressam enzimas extracelulares o que facilita o processo de extração e purificação. Os fungos filamentosos também são hábeis em degradar materiais lignocelulósicos, o que permite o cultivo com resíduos agroindustriais como fonte de carbono para seu crescimento (13).

A adaptação de tecnologias e processos para aproveitamento econômico de co-produtos das atividades da agroindústria vem ganhando importância para o Brasil e o mundo (14). Uma das aplicações em potencial desses resíduos consiste na sua utilização como nutriente e fonte de carbono em bioprocessos para obtenção de produtos de maior valor agregado, tais como enzimas, alcoóis, ácidos orgânicos, aminoácidos, metabólitos secundários biologicamente ativos e compostos aromáticos (15).

Muitas enzimas já foram produzidas por cultivos de fungos filamentosos em meios contendo resíduo da agroindústria, como proteases em farelo de trigo, amilases em casca de mandioca (16), xilanases em bagaço de cana e casca de soja (17), pectinases extraídas de cultivo em casca de maracujá (18), entre outras. Resíduos agroindustriais da cultura da soja são abundantemente produzidos no Brasil e no mundo e podem ser empregados para a obtenção de produtos biotecnológicos tanto pela sua alta disponibilidade quanto por apresentarem fonte alternativa nutritiva de baixo valor comercial (19).

A procura industrial por tecnologias alternativas que tenham alta produtividade, consumindo menos recursos e com menos impacto ambiental é 
crescente no cenário mundial (15). Desta forma, a busca por novas $\beta$-galactosidases de origem fúngica, produzidas por cultivo a partir de resíduo da soja, com características compatíveis para aplicabilidade industrial se torna interessante do ponto de vista biotecnológico, econômico e ambiental. 


\section{REVISÃO DA LITERATURA}

\subsection{INTOLERÂNCIA À LACTOSE}

A intolerância aos alimentos é uma reação desagradável, reproduzível a um alimento específico ou a um ingrediente alimentício, que ocorre sempre que o alimento é ingerido (20). Pode ocorrer devido a falha no processo digestivo em virtude de deficiências enzimáticas, uma vez que, a digestão depende da ação de enzimas capazes de degradar os alimentos (20).

Entre as intolerâncias alimentares destaca-se a intolerância a lactose, caracterizada pela má absorção intestinal da lactose, carboidrato mais comum do leite dos mamíferos. Essa intolerância pode afetar pessoas de todas as faixas etárias. Estima-se que $70 \%$ da população mundial adulta têm problemas em digerir a lactose devido à redução ou ausência da enzima $\beta$-galactosidase no intestino delgado (3). Para que não ocorra má digestão de lactose, é necessário que haja pelo menos $50 \%$ de atividade da $\beta$-galactosidase no intestino (21).

A intolerância à lactose é mais comum em alguns grupos étnicos do que em outros, $75 \%$ dos africanos e americanos e 90\% dos asiáticos tem intolerância a lactose (22). No Brasil, segundo Ministério da Saúde, 25\% dos brasileiros apresentam alguma dificuldade em digerir a lactose $(23,24)$. Estudos realizados nas diferentes regiões brasileiras mostram uma prevalência de intolerantes à lactose de $8 \%$ a $45 \%$ nas regiões sudeste e sul e de $75 \%$ no nordeste do país $(23,25)$. Esses dados podem ser aumentados com o passar do tempo, devido à incidência de hipolactasia primária, onde a maioria das pessoas que não apresentavam sintomas podem passar a ter desconforto com a ingestão de lactose (22).

A intolerância à lactose pode ser classificada em três grupos, de acordo com o modo que se manifesta: hipolactasia primária (deficiência primária), hipolactasia secundária (deficiência secundária) e deficiência congênita $(1,26)$. A hipolactasia primária, é um tipo de intolerância caracterizada pela diminuição da atividade da enzima $\beta$-galactosidase na mucosa do intestino delgado. Após o desmame, ocorre 
uma redução geneticamente programada e irreversível da atividade $\beta$-galactolítica na maioria das populações do mundo (27), cujo mecanismo parece estar associado a mutação de um gene regulador de $\beta$-galactosidase. A exposição contínua ao leite estendida após o desmame pode estar relacionada a expressão do gene regulador (28).

Segundo a Federação Brasileira de Gastroenterologia, pessoas com predisposição genética a intolerância, possuem uma má absorção da lactose assintomática, que ao longo do tempo em decorrência da diminuição de $\beta$ galactosidases, perderá a capacidade de digerir a lactose e apresentará sintomas (21). A prevalência da hipolactasia primária no centro sul da Europa é alta, chegando próximo a 100\% na Ásia e Oriente Médio, em torno de 10\% entre brancos do nordeste da Europa e 90\% de negros africanos (21, 27). Especula-se que devido à miscigenação racial, no Brasil até $50 \%$ da população possa vir a desenvolver a hipolactasia primária. A prevalência em adultos (intolerância a lactose mais comum) é de $57 \%$ entre brasileiros brancos e mulatos, chegando a $80 \%$ entre brasileiros negros e próxima a 100\% entre brasileiros de descendência japonesa (21).

A intolerância adquirida ou hipolactasia secundária é aquela decorrente de condições patológicas que afetam a integridade da mucosa intestinal. Diferentemente da hipolactasia primária, a hipolactasia secundária é transitória e na maioria das vezes reversível (27). Depois que o dano é reparado, a mucosa regenera-se e na maioria das vezes passa a produzir a $\beta$-galactosidase novamente, ainda que seja uma das últimas enzimas que volta a ser produzida. É um tipo de intolerância muito comum afetando aproximadamente $3 / 4$ da população mundial (29, 30). Podem fazer parte desse grupo, pessoas portadoras de doenças que causam lesões na mucosa entérica, ou que aumentam significativamente o tempo de trânsito intestinal como nas enterites, giardíase, celíacos, pessoas com Síndrome do Intestino irritável, Doença de Crohn, enterites induzidas por drogas ou irradiação (27).

Outra incapacidade de digerir a lactose é a intolerância congênita, uma doença genética autossômica recessiva grave, rara que afeta inicialmente recémnascidos. É considerada uma condição permanente, e parece estar associada a uma mutação no gene da lactase-florizina hidrolase (LPH). Recentemente duas 
mutações heterozigóticas, foram identificadas dentro da região codificadora de LPH em crianças japonesas portadoras de deficiência congênita a lactose (31).

Em todas as formas de intolerância à lactose, os indivíduos podem apresentar um conjunto de sintomas caracterizado por uma síndrome clínica de desconforto intestinal após a ingestão de lactose. As pessoas com deficiência de $\beta$ galactosidase, por não possuírem a capacidade de digerir o dissacarídeo, quando consomem leite ou derivados, não absorvem a lactose não hidrolisada no intestino delgado. Isto eleva a pressão osmótica e a retenção de água no cólon provocando aumento nas contrações peristálticas. Em seguida, as bactérias colonizadoras do intestino grosso fermentam a lactose produzindo gases (carbônico e hidrogênio) e ácidos orgânicos de cadeia curta, metabólitos acetato, butirato e propionato resultando em irritação da parede intestinal, inchaço, diarreia, dores abdominais, vômitos e desnutrição grave $(1,27,30,31)$.

Os sintomas sistêmicos podem manifestar-se como desconfortos secundários caracterizados por dor de cabeça, dificuldade de concentração, dores musculares e úlceras bucais (29). A intensidade do desconforto está associada a quantidade de lactose que o organismo de cada pessoa consegue suportar (22) e com a microbiota intestinal responsáveis pelos metabólitos da fermentação da lactose (21).

O diagnóstico da intolerância à lactose pode ser feito por um exame chamado de "teste respiratório de hidrogênio expirado". Neste teste, o hidrogênio produzido pela fermentação da lactose absorvido é detectado na respiração (20). Um segundo teste realizado para diagnosticar a intolerância é através da quantificação da glicose no sangue após uma sobrecarga de lactose (Teste de tolerância oral à lactose) 0 teste mensura de forma indireta a má absorção. Por fim, também existe teste genético, em que os genes do paciente são estudados para saber se existe carga para a intolerância (21).

O tratamento clássico para intolerância à lactose é a retirada de produtos lácteos da alimentação para a remissão dos sintomas. A Tabela 1 mostra o teor de lactose de alguns produtos lácteos. Porém, a restrição desses produtos da dieta por 
tempo prolongado pode favorecer a ocorrência de deficiências nutricionais de cálcio, fósforo e vitaminas $(1,2)$.

Tabela 1 - Principais alimentos que contém lactose

\begin{tabular}{ccc}
\hline Teor de lactose (\%) & Alimentos & Referências \\
\hline 4 a $5 \%$ & Leite de vaca & $(32)$ \\
5 a $50 \%$ & Leite em pó, leite condensado, \\
& sorvetes a base de leite e & $(21)$ \\
70 a $80 \%$ & queijo ricota \\
6 a $7 \%$ & Leitrato seco de soro de leite. \\
2 a $3 \%$ & logurte desnatado ou integral, \\
& coalhada caseira & $(32)$ \\
$0,01 \%$ a $2 \%$ & Queijo minas, mussarela, \\
& prato, parmesão, catupiri, \\
& Yakult ${ }^{\circledR}$, creme de leite
\end{tabular}

No entanto, para que os indivíduos intolerantes se beneficiem dos nutrientes do leite, existem no mercado produtos lácteos livres de lactose ou com baixo teor de lactose, obtidos a partir da hidrólise enzimática utilizando $\beta$-galactosidase. Porém, o custo dos produtos deslactosados ainda é elevado quando comparado com produtos não deslactosados. Esse fato está muito relacionado com o alto custo da enzima utilizada no processo.

Segundo a portaria № 29 de 13/01/1998 da Secretaria de Vigilância Sanitária, do Ministério da Saúde, alimentos especialmente formulados para atender às necessidades de portadores de intolerância à ingestão de dissacarídeos, podem conter no máximo $0,5 \mathrm{~g}$ do nutriente em referência, por $100 \mathrm{~g}$ ou $100 \mathrm{~mL}$ do produto final a ser consumido (33).

Outra alternativa para pessoas com intolerância, é a administração oral de suplementos alimentares como comprimidos à base da enzima $\beta$-galactosidase. Estes comprimidos podem ser utilizados simultaneamente com a ingestão de 
produtos contendo lactose na tentativa de minimizar a ocorrência de sintomas (21, 34).

\subsection{BETA-GALACTOSIDASE}

A enzima $\beta$-galactosidase ( $\beta$-D-galactohidrolase, E.C 3.2.1.23) é usualmente chamada de lactase. A enzima pertence ao grupo das $\beta$-glicosidases (35), classificada como uma hidrolase com capacidade de catalisar a hidrólise do grupamento terminal $\beta$-D-galactosil de substratos, tais como a lactose, em glicose e galactose. Dependendo das condições de reação também podem catalisar reações de transgalactosilação com outras moléculas aceptoras sintetizando galactooligossacarideos (Figura 1) (8).

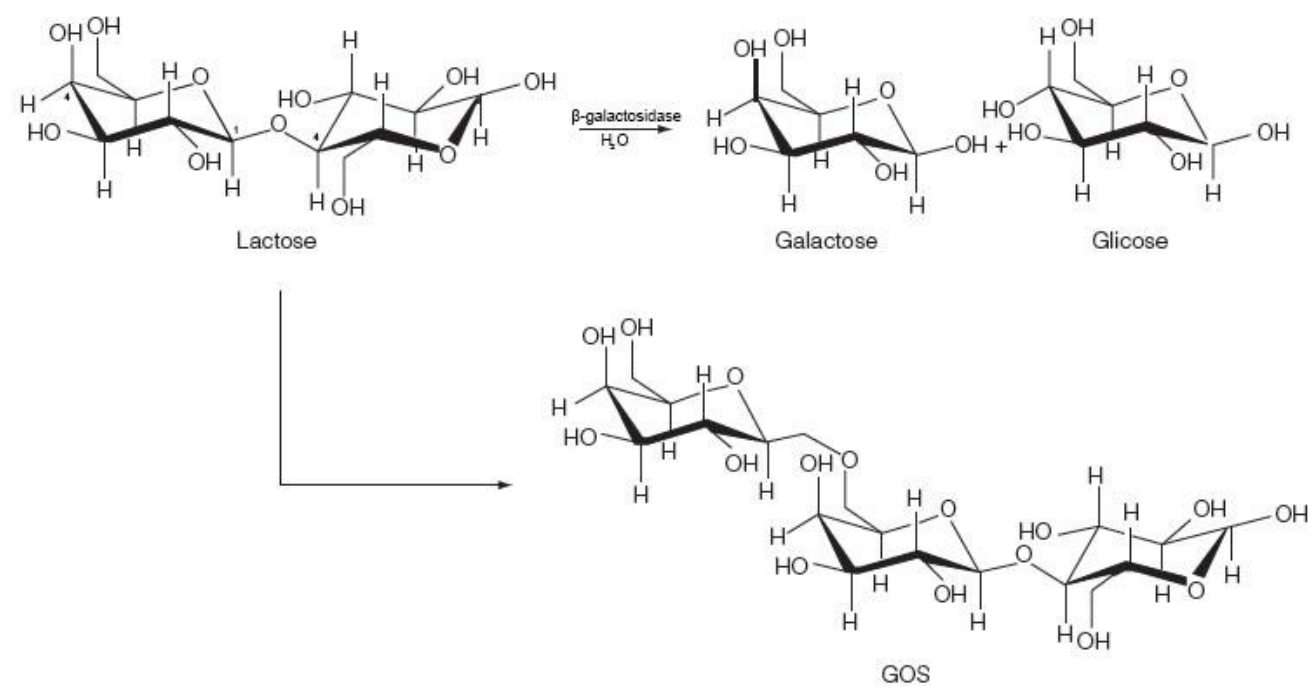

Figura 1- Rotas de conversão da lactose pela enzima $\beta$-galactosidase $(32,36)$.

A lactose (4-O- $\beta$-D-galactopiranosil-D-glicose) é um dissacarídeo sintetizado nas células alveolares das glândulas mamárias a partir de glicose sanguínea (1). Este açúcar é constituído pela ligação glicosídica $\beta 1-4$ entre a hidroxila do $C 1$ (anomérico) de uma molécula de galactose ( $\beta$-D-galactose) com a hidroxila do C4 de uma molécula de glicose ( $\alpha$-D-glicose). A lactose é considerada um açúcar redutor, porque o grupo no carbono anomérico da porção glicose está livre para reagir com agentes oxidantes (37). 
No organismo humano saudável, a $\beta$-galactosidase está localizada na borda do epitélio intestinal, onde realiza a hidrólise da lactose. A enzima cliva a ligação glicosídica $\beta$-1-4 entre os monossacarídeos glicose e galactose, deixando-os livre para serem absorvidos pelas células epiteliais do intestino, cuja concentração está aumentada nos primeiros anos de vida (31).

As $\beta$-galactosidases também são encontradas na natureza, distribuídas entre vegetais, órgãos de animais (intestino, cérebro e placenta) e microrganismos $(9,38)$. Nas plantas são encontradas em pêssegos, amêndoas, algumas espécies de rosas selvagens, sementes de rabanete e sementes germinadas de grão de bico $(20,39)$. A função das $\beta$-galactosidases nas plantas parece estar relacionada com a capacidade da enzima em degradar açúcares da parede vegetal favorecendo o amadurecimento das frutas e germinação das sementes, sendo sua atividade aumentada nesta fase (39). As $\beta$-galactosidases de origem vegetal são pouco utilizadas devido ao seu alto custo e baixa produtividade quando comparada com as de origem microbiana (9).

As $\beta$-galactosidases de origem microbiana podem ser produzidas por bactérias, fungos filamentosos e leveduras $(5,9)$. Algumas $\beta$-galactosidases bacterianas descritas pela literatura são as de Escherichia coli e de lactobacilus (Lactobacillus reuteri, Lactobacillus fermentum, Lactobacillus crispatus) (38). A $\beta$ galactosidase obtida de Escherichia coli foi extensamente estudada, mas o seu uso industrial é dificultado pelo fato de não ser considerado seguro para aplicações alimentares $(9,40)$. No entanto, esta enzima encontra-se comercialmente disponível para fins analíticos (40).

As $\beta$-galactosidases de lactobacilos apresentam grande potencial na produção de galacto-oligossacarídeos e são comumente usadas em estudo de expressão gênica em sistemas procarióticos incluindo Escherichia coli e Pichia pastoris visando a termoestabilidade enzimática e alta produtividade (38).

A produção de $\beta$-galactosidase a partir de fungos filamentosos e leveduras vêm sendo bastante pesquisada devido as suas características biotecnológicas favoráveis à escala industrial $(5,41)$. Há relatos na literatura de estudos de produção e utilização de $\beta$-galactosidase a partir de fungos filamentosos como 
Peniccillium chrysogenum (42), Trichoderma sp, Penicillium sp (6), Aspergillus oryzae (43), Aspergillus niger, Aspergillus alliaceus (44) e leveduras como Kluyveromices lactis (45).

As propriedades das $\beta$-galactosidases dependem de diversos fatores variando de acordo com sua origem e microrganismo produtor (9, 46). O peso molecular, o comprimento da cadeia de aminoácidos, a posição do sítio ativo, $\mathrm{pH}$ ótimo e termoestabilidade são características significativamente influenciadas pela fonte microbiana produtora da enzima (47). Por exemplo, a $\beta$-galactosidase, extraída da Escherichia coli possui a maior peso molecular (520 kDa a $850 \mathrm{kDa}$ ), enquanto as de baixo peso molecular são geralmente de origem fúngica como as que foram extraídas de Saccharoyces fragilis (201 kDa) e de Aspergillus oryzae (90 kDa) (46).

As $\beta$-galactosidases expressas por fungos filamentosos geralmente são mais ácidas dos que as produzidas a partir de bactérias e levedura. A escolha da enzima vai depender da condição da reação a ser catalisada. Para a hidrólise do leite normalmente são utilizadas enzimas produzidas por leveduras, cujo $\mathrm{pH}$ ótimo $(\mathrm{pH}$ 6,0-7,0) é próximo a neutralidade. Por outro lado, para a hidrólise de soro de leite, enzimas de origem fúngicas $(\mathrm{pH} 3,0-5,0)$ são mais utilizadas. Além disso, as $\beta$ galactosidases de fungos filamentosos, ao contrário das produzidas por leveduras, parecem ser ativas sem a presença de íons como co-fatores (47).

A possibilidade de explorar a atividade da $\beta$-galactosidase industrialmente, surgiu com a introdução de diversos substratos com propriedades cromogênicas. Como exemplo de substratos citam-se, 5-bromo-4-chloro-3-indoyl- $\beta-D$ galactopyranoside ( X-Gal) e o-nitrophenyl- $\beta$-D-galactopyranoside (ONPG) (48).

A importância industrial da $\beta$-galactosidase está em sua aplicação tanto na indústria alimentícia como na indústria farmacêutica. Entre as $\beta$-galactosidases mais utilizadas industrialmente estão principalmente as de leveduras (Kluyveromycis lactis, Kluyveromyces fragilis) e de fungos (Aspergillus niger e Aspergillus oryzae), as quais são empregadas em produtos e alimentos lácteos de forma segura $(38,49)$. Algumas das preparações comerciais de $\beta$-galactosidases de origem microbiana e seus fornecedores, estão apresentadas na Tabela 2. Estas enzimas, na sua maioria, têm seu uso voltado para aplicação na indústria alimentícia. 
Tabela 2 - Preparações comerciais de $\beta$-galactosidase de diferentes fontes microbianas

\begin{tabular}{|c|c|c|}
\hline Origem & Nome Comercial & Fornecedor \\
\hline Aspergillus oryzae & Enzeco® fungal lactase & $\begin{array}{l}\text { Enzyme Development } \\
\text { Corporation (EDC), New } \\
\text { York, USA }\end{array}$ \\
\hline Aspergillus oryzae & $\begin{array}{l}\text { Fungal lactase for } \\
\text { alternative strains }\end{array}$ & $\begin{array}{l}\text { Enzyme Development } \\
\text { Corporation (EDC), New } \\
\text { York, USA }\end{array}$ \\
\hline Aspergillus oryzae & Tolerase & $\begin{array}{l}\text { DSM Food Specialties, } \\
\text { Heerlen, Netherlands }\end{array}$ \\
\hline Aspergillus niger & Klerzyme 150 & $\begin{array}{l}\text { DSM Food Specialties, } \\
\text { Heerlen, } \\
\text { Netherlands. Holanda }\end{array}$ \\
\hline Aspergillus niger & Rapidase & $\begin{array}{l}\text { DSM Food Specialties, } \\
\text { Heerlen, } \\
\text { Netherlands. Holanda }\end{array}$ \\
\hline Bacillus circulans & Biocon NTL 3000 & $\begin{array}{l}\text { Biocon, Barcelona, } \\
\text { Spain }\end{array}$ \\
\hline Kluyveromyces lactis & Biolactasa-NL & $\begin{array}{l}\text { Biocon, Barcelona, } \\
\text { Spain }\end{array}$ \\
\hline Kluyveromyces lactis & Enzeco Lactase NL & $\begin{array}{l}\text { Enzyme Development } \\
\text { Corporation (EDC), New } \\
\text { York, USA }\end{array}$ \\
\hline Kluyveromyces lactis & Maxilact L200 & $\begin{array}{l}\text { DSM Food Specialties, } \\
\text { Heerlen, Netherlands }\end{array}$ \\
\hline Kluyveromyces lactis & Lactozym Pure 2600L & $\begin{array}{l}\text { Novozymes Latin } \\
\text { America, Araucária, } \\
\text { Brasil }\end{array}$ \\
\hline *** & Lactaid $\AA$ & $\begin{array}{l}\text { McNeil nutritionals, } \\
\text { Washington, USA }\end{array}$ \\
\hline
\end{tabular}

*** Dado não encontrado. Fonte: Guerrero et.al, 2015 modificado (50). 


\subsection{APLICABILIDADE DA BETA-GALACTOSIDASE NA INDÚSTRIA ALIMENTÍCIA}

ß-galactosidases, são enzimas amplamente utilizadas para aplicações industriais, tanto em reações de hidrólise da lactose como nas reações de transgalactosilação. Nas reações de hidrólise a aplicação está em produtos lácteos para intolerantes à lactose e melhoria das características tecnológicas e sensoriais de alimentos. Na transgalactosilação a atividade da $\beta$-galactosidases está na biossíntese de galacto-oligossacarídeos - produção de prebióticos $(8,51)$.

\subsubsection{Hidrólise da lactose}

A hidrólise enzimática da lactose é a principal aplicação da $\beta$ - galactosidase. A enzima é amplamente aplicada para hidrolisar a lactose presente tanto no leite quanto no soro de leite preservando as propriedades nutricionais dos produtos obtidos (9).

A enzima $\beta$-galactosidase é amplamente utilizada na tecnologia de alimentos lácteos para prevenir ou reduzir os sintomas associados a má digestão da lactose por indivíduos intolerantes. A hidrólise da lactose conferida pela adição da enzima $\beta$ galactosidase no leite antes do consumo é um dos métodos explorados pela indústria de laticínio. Alguns trabalhos, consideram satisfatório para intolerantes que a lactose presente no leite seja hidrolisada em no mínimo 90\% (52). Para a legislação brasileira o mínimo de 95\% (33). O grau de hidrólise pode estar relacionado com as propriedades da enzima e com as condições de processamento (20).

O leite hidrolisado, no entanto, tem um sabor mais adocicado e um custo mais elevado quando comparado com o leite natural. O custo está muito relacionado ao desafio que a indústria enfrenta em obter enzimas mais baratas, com alta especificidade e com propriedades compatíveis ao processo de hidrólise. Somado a isso, outro fator que limita o rendimento das reações de hidrólise é a inibição competitiva que os produtos da reação, glicose e galactose, exercem sobre a enzima $\beta$-galactosidase $(52,53)$. 
Outra aplicação industrial beneficiada pela hidrolise da lactose catalisada pela $\beta$-galactosidase é o melhoramento sensorial de produtos derivados de laticínios como o leite condensado, doce de leite e produtos fermentados como o iogurte (20, 54).

A lactose tem como características a baixa solubilidade em água (15 a 20\%) e baixo poder adoçante, quando comparado a outros açúcares $(20,30)$. Esta baixa solubilidade pode causar a cristalização e, consequentemente problemas tecnológicos de arenosidade no processamento de produtos lácteos. Uma alternativa para aumentar a solubilidade e o poder adoçante desses produtos é hidrolisar a lactose visto que, os produtos da hidrólise, glicose e galactose, possui um poder adoçante maior que a lactose (30). Além disso, a hidrólise confere poder edulcorante, aumentando seu uso em xaropes alimentícios para aplicações na confeitaria $(20,55)$.

A lactose também por apresentar característica higroscópica pode causar problemas na textura de produtos refrigerados (40). Para a indústria de congelados lácteos a hidrólise da lactose é interessante, uma vez que, a remoção da lactose pode provocar uma redução de mais de $50 \%$ do ponto de congelamento $(20,56)$, diminuindo problemas de precipitação e cristalização da lactose em certos alimentos altamente refrigerados sendo atrativo para indústria de doces e sorvetes (8).

Existem dois tipos de hidrólise da lactose: ácida e enzimática. No método químico, normalmente são usados ácidos fortes e altas temperaturas o que pode acarretar em problemas tecnológicos como mudança do sabor, coloração e alteração das propriedades nutricionais, impedindo sua utilização em alguns alimentos $(9,30)$. Quando comparado com a hidrólise ácida, a hidrólise enzimática da lactose é tecnicamente mais conveniente, pois as enzimas são altamente específicas e geralmente agem sob condições de reações mais brandas que produtos químicos (ácidos) tradicionais. Além disso, são facilmente biodegradáveis e geralmente levam à redução ou nenhuma toxicidade quando chegam ao meio ambiente após a sua utilização industrial (15). Estas propriedades das enzimas permitem que os fabricantes obtenham o produto com qualidade semelhante ou até melhor através da hidrólise enzimática, utilizando menos matéria prima, agentes químicos, energia e com resíduos menos problemáticos ao meio ambiente $(15,57)$. 
Somado a isso, a hidrólise enzimática pode resultar em subprodutos desejáveis em determinadas situações, como é o caso da hidrólise de dissacarídeos catalisada pela $\beta$-galactosidase, onde o produto final pode ser enriquecido com galacto-oligossacarídeos. No entanto, o alto custo das enzimas é uma desvantagem da hidrólise enzimática, o que vem motivando estudos na área de produção enzimática em meios não convencionais de baixo custo como resíduos agrícolas.

\subsubsection{Síntese de galacto-oligossacarídeos (GOS)}

Durante a hidrólise da lactose catalisada pela $\beta$-galactosidase, além dos principais produtos de hidrólise, que são glicose e galactose, quantidades consideráveis de galacto-oligossacarídeos (GOS) podem ser formadas (Figura 1).

Galacto-oligossacarídeos são oligossacarídeos, definidos como prebióticos, alimentos funcionais não digeríveis benéficos ao organismo humano ou animal. No intestino apresentam efeitos fisiológicos semelhantes aos da fibra alimentar. Além disso, estimulam seletivamente o crescimento e/ou atividade de bactérias no cólon (Bifidobacterias), reduzindo a formação de metabólitos tóxicos, auxiliando no processo de constipação e na produção de vitaminas do complexo B conferindo benefícios à saúde $(3,58,59)$.

GOS são produzidos a partir de substratos ricos em lactose $(54,60)$, através da reação de transgalactosilação $(3,59)$. Dependendo das condições de reação a lactose serve como doador de unidades de galactosil, pela transferência do resíduo D-galactosil do substrato para outra molécula de lactose (58). Primeiro ocorre a formação do complexo galactosil, enzima liberando glicose. Depois, duas reações podem ocorrer simultaneamente, hidrólise e transgalactosilação, dependendo da porção galacosil aceptor presente no meio da reação. Quando o aceptor é a água, ocorre hidrólise e a lactose é hidrolisada em glicose e galactose, enquanto que quando o aceptor é galactose (ou potencialmente qualquer açúcar), a transferência do grupo galactosil acontece e uma mistura complexa de GOS é formada (10).

A predominância para a síntese de GOS e a composição da fração GOS formada pode ser significativamente afetada pela origem da $\beta$-galactosidase e pelas 
condições da reação (concentração de lactose, quantidade de enzima, temperatura, tempo e pH) (3). A alta concentração inicial de lactose favorece a síntese de GOS, o que pode ser justificado pelo aumento da disponibilidade do sacarídeo galactosil aceptor e pela diminuição da disponibilidade de água (61).

O mecanismo de transgalactosilação por $\beta$-galactosidases propriamente dito, recebeu menos atenção quando comparado com o mecanismo de hidrólise. Todos os dados atualmente publicados sobre o mecanismo de transgalactosilação fazem inferências a partir da reação hidrolítica ao invés da observação direta de transgalactosilação. Não se sabe se as interações no sítio ativo são diferentes quando o aceptor é um sacarídeo em comparação com a água. No entanto sabe-se que enzimas tem diferente seletividade para água e sacarídeo resultando em diferentes rendimentos. Provavelmente, a diferença nos rendimentos de GOS é resultado de diferenças estruturais de $\beta$-galactosidase de diferentes fontes $(10,61)$.

$\mathrm{Na}$ última década, aumentaram os interesses pelos GOS tanto no âmbito científico como industrial. As reações com atividade de transgalactosilação para a produção de galacto-oligossacarideos (GOS), tem se destacado pela sua utilização em alimentos funcionais ou de baixa caloria, confeitarias, pães, bebidas e aditivos em fórmulas infantis (61).

\subsection{APLICABILIDADE NA INDÚSTRIA FARMACÊUTICA}

Atualmente, as enzimas são amplamente utilizadas como agente terapêutico. Algumas delas são administradas oralmente em uso clínico ou estão em desenvolvimento como coadjuvantes no tratamento de patologias, tais como doença celíaca e a fenilcetonúria. Como medicamento as enzimas são de interesse devido a sua elevada atividade, seletividade e pela possibilidade de manipulação de suas propriedades (62). No entanto, a administração da enzima de grau farmacêutico por via oral é desafiadora devido ao potencial de inativação destas macromoléculas no ambiente hostil do trato gastrointestinal (62). 
A terapia de substituição enzimática oral tem por objetivo a degradação dos componentes alimentares potencialmente prejudiciais, ou complementação de enzimas digestivas produzidas pelo organismo em quantidades insuficientes (62).

$\mathrm{Na}$ indústria farmacêutica a aplicação da enzima $\beta$-galactosidase está na elaboração de suplemento alimentar em formulações orais, pois muitos dos sintomas da intolerância à lactose podem ser minimizados pelo consumo de $\beta$ galactosidase exógena antes ou durante a ingestão de leite ou derivados lácteos (7).

Suplementos de $\beta$-galactosidase comercializados na forma de comprimido ou cápsulas geralmente são de origem fúngica como do gênero Aspergillus (Aspergillus niger e Aspergillus Oryzae) e lactobacilos (34, 63). Porém, nem sempre esses produtos comercializados são adequados para a hidrólise da lactose in vivo, devido suas características físico-químicas incompatíveis com as condições encontradas no trato gástrico superior (7). A maioria destes suplementos precisam de um revestimento especial para que a enzima chegue ativa no intestino. De forma, que o revestimento só seja removido quando o comprimido atinja o trato intestinal (63).

As $\beta$-galactosidases também podem ser aplicadas em estudos analíticos (41) e outros processos de biotecnologia de importância médica como marcador gênico em diagnóstico molecular $(8,41)$.

Alguns biossensores amperométricos para lactose foram desenvolvidos por $\beta$ galactosidase imobilizada para a estimativa da lactose em amostras de leite e seus derivados. Biossensores, apresentam vantagens tais como confiabilidade, sensibilidade, precisão, facilidade de manuseio e baixo custo em comparação com métodos convencionais de detecção de lactose. $\beta$-galactosidases imobilizadas são um atrativo para a indústria de biossensores ideais para aplicações biomédicas (41).

A natureza de tais aplicações muitas vezes requer galactosidases numa forma purificada e com propriedades claramente definidas, incluindo determinação de substratos específicos, baixa sensibilidade aos inibidores, alta eficiência e estabilidade sob condições distintas (8).

As $\beta$-galactosidases microbianas usadas, tanto na indústria alimentícia quanto farmacêutica, incluem tanto microrganismos procariontes como eucariontes. Essas 
enzimas podem ser purificadas diretamente a partir de organismos fúngicos ou produzidos de forma recombinante $(41,44)$.

A busca de novas fontes produtoras de enzimas, especialmente as de origem microbiana, é cada vez maior devido às suas aplicações em uma grande variedade de processos industriais $(64,65)$. Após os antibióticos, as enzimas são os produtos microbianos mais explorados na indústria biotecnológica, tornando possível o fornecimento de enzimas adaptadas as condições de novos processos e permitindo uma maior expansão da sua utilização industrial $(65,66)$.

\subsection{FUNGOS FILAMENTOSOS DO SOLO CERRADO BRASILEIRO}

Microrganismos podem ser utilizados como fonte de agentes ativos uma vez que, produtos naturais tem um papel importante no desenvolvimento de fármacos e enzimas $(13,67)$. Os fungos, em especial, têm participação expressiva neste cenário.

O reino Fungi consiste em um grupo extenso e diversificado de organismos eucarióticos que inclui microrganismos como leveduras (unicelulares) ou fungos filamentosos (pluricelulares), sendo a última, a forma mais abundante (67). Mais de 70.000 espécies de fungos já foram descritas. Porém, estima-se que existe pelo menos 1,5 milhões de espécies no mundo, ou seja apenas $5 \%$ são conhecidos (68, 69).

O crescimento, variabilidade e flexibilidade metabólica dos organismos fúngicos, são uma resposta às condições físico-químicas do meio ambiente que os rodeia. Os fungos podem modificar seu ambiente e utilizar os compostos químicos presentes no meio, como fonte de energia e como elementos básicos para seu crescimento e reprodução, o que permite sua ubiquidade (68).

$\mathrm{Na}$ natureza, existem polímeros (carboidratos, lipídeos) em abundância que podem ser aproveitados pelos fungos filamentosos como fontes nutricionais, principalmente resíduos de origem vegetal. Os componentes dos materiais lignocelulósicos durante a decomposição são progressivamente despolimerizados 
por complexos enzimáticos $(68,70)$. A nutrição dos fungos é do tipo absortiva, graças à secreção extracelular desses sistemas enzimáticos por eles produzido que degradam macromoléculas em moléculas de menor tamanho possibilitando a incorporação dessas moléculas pequenas em seu organismo utilizadas como fonte de energia para seu crescimento $(13,18,68)$.

Os fungos filamentosos se adaptam ao aproveitamento de uma ampla gama de substratos, por secretarem enzimas extracelulares e pela sua particular forma de crescimento filamentoso. As células alargadas de crescimento apical (hifas) favorecem a penetração do fungo nos resíduos, facilitando sua utilização para produção de substâncias de interesse como as enzimas (68).

Essa eficiência na degradação lignocelulósica contribui para a grande capacidade adaptativa dos fungos colonizar diferentes ambientes, com variações de temperaturas, umidade, $\mathrm{pH}$, nutrientes, pressão, entre outros $(11,17)$.

Em caso de fungos isolados do solo, sabe-se que o tipo de solo também influencia a estrutura das comunidades microbianas, em função de tamanho de partículas, $\mathrm{pH}$, capacidade de intercâmbio de íons e o conteúdo de matéria orgânica. A diversidade das comunidades microbianas no solo, também sofre influência dos compostos (etileno, carboidrato, vitaminas, ácidos orgânicos, polissacarídeos e enzimas) liberados no entorno pelas raízes das plantas (71).

O solo, em particular, é um nicho ecológico bastante explorado para microrganismos produzirem metabólitos biologicamente ativos, como antibióticos produzidos por bactérias (Streptomice) e fungos $(72,73)$. Pesquisadores enfatizam a necessidade de explorar diferentes tipos de solos e novos nichos como florestas tropicais, costas marinhas e mangues na busca de compostos farmacologicamente ativos (73).

O solo do cerrado centro-oeste brasileiro, possui biodiversidade significativa e algumas peculiaridades (baixa umidade e altas temperaturas) interessantes na expectativa de encontrar microrganismos que sejam capazes de expressar enzimas com características industriais desejáveis. Por isso, este bioma vem sendo explorado com uma boa perspectiva na busca inovadora de fontes enzimáticas. 
A procura alternativa de fungos produtores de enzimas, entre os fungos que crescem em condições extremas de temperatura e umidade, é atraente. Pois, estes microrganismos são estimulados a expressar vários metabólitos com a função de promover a adaptação e sobrevivência a estas condições (74).

Fungos filamentosos, por serem organismos metabolicamente ativos, são explorados comercialmente como fontes produtoras de uma grande variedade de enzimas e de outros metabólitos. Diversas espécies, que dão origem a compostos bioativos, são conhecidas e as pesquisas que visam o isolamento desses produtos são muito expressivas em todo o mundo (74). Entre os exemplos de compostos obtidos de microrganismos de origem fúngica estão 0 antibiótico penicilina (Penicillium), imunossupressor ciclosporina (Chephalosporium acremonium) e o hipocolesterolemiante lovastatina (Aspergillus terreus e Monascus ruber) (75-77), enzimas, xilanases (Aspergillus terreus (78), Penicillium capsulatum) (79) amiloglicosidases (Aspergillus niger) (80), pectinases e $\beta$-galactosidases (Aspergillus oryzae) $(18,43)$. Alguns destes são comercializados enquanto outros, são potencialmente valiosos em biotecnologia $(13,81)$.

Os fungos dos gêneros Aspergillus e Penicillium tem sido muito utilizado na busca de compostos bioativos. Sendo que, aproximadamente 6500 metabólitos bioativos de fungos microscópicos, mais de $30 \%$, foram obtidos destes dois gêneros $(13,69,82)$. A importância econômica dos fungos vai além dos seus produtos de metabolismo, sendo alvo de estudos para o desenvolvimento e comercialização de novos produtos obtidos a partir da engenharia genética (77).

No entanto, alguns fungos podem produzir metabólitos com propriedades tóxicas (micotoxinas) como é caso das aflotoxinas produzida por alguns fungos do gênero Aspergillus (77). Por este motivo os fungos cujos metabólitos serão utilizados comercialmente devem ser criteriosamente avaliados e classificados como seguros. Algumas espécies de fungos filamentosos de importância industrial como Aspergillus niger, Aspergillus oryzae, Trichoderma reesei, Acremonium chrysogenum e Penicillium chrysogenum, considerados seguros, possuem o status Generally recognized as safe (GRAS) de acordo com a Food and Drug Administration (FDA), o que permite o uso de seus metabólitos nas indústrias de alimentos e bebidas para uso humano e em preparações de rações animais (13). 
O Aspergillus niger e Aspergillus oryzae fazem parte da seção taxonômica "Aspergillus Section Nigri", que é considerada GRAS $(83,84)$. O "Aspergillus black" é um importante grupo de espécies na biotecnologia, usadas na indústria para produzir enzimas hidrolíticas e também como candidatos para manipulação genética na indústria de biotecnologia. O Aspergillus foetidus possui características morfológicas semelhante ao Aspergillus niger. Apresenta micélio de coloração variando de marrom escuro a preto muito semelhante ao Aspergillus niger o que indica que esta espécie pertence a "Aspergillus Section Nigri" (85, 86). Dessa forma, Aspergillus foetidus, pela similaridade que tem com fungos pertencentes à seção Nigri, está sendo estudado no que tange sua potencial aplicação biotecnológica (86).

Uma grande vantagem da prospecção química de metabolitos fúngicos em relação as demais fontes, é pelo fato de que esses microrganismos podem ser cultivados em larga escala em fermentadores não havendo prejuízo ao ecossistema, como pode ocorrer com a retirada de plantas e algas de áreas naturais. Também, evitam-se os problemas éticos como os que podem advir da prospecção de metabólitos bioativos a partir de insetos, anfíbios, entre outras espécies animais. Além disso, a produção de metabólitos e enzimas de origem microbiana, quando comparada ao processo que utilizam subprodutos de origem vegetal é mais vantajosa por ser planejada de forma a evitar efeitos de sazonalidade de culturas, e ser mais versátil quanto à disponibilidade de matéria-prima (87).

Os fungos filamentosos são especialmente valorizados para a produção de enzimas do ponto de vista industrial e econômico, pela capacidade de secretá-las ao meio extracelular, o que facilita sua recuperação do meio líquido de fermentação $(49,88)$.

A habilidade dos fungos filamentosos de crescerem em uma grande variedade de substrato (89), tem despertado interesse no aproveitamento de resíduos agroindustriais de baixo custo como componente alternativo do meio fermentativo desses microrganismos (13). 


\subsection{RESÍDUO AGROINDUSTRIAL DA SOJA}

No Brasil, a produção agrícola é uma das mais importantes do mundo, produzindo e exportando café, soja, açúcar da cana, frutas e subprodutos a base destes, gerando grandes quantidades de resíduos (90). Nos últimos anos houve um aumento dos estudos na tentativa de tornar mais eficiente a utilização desses resíduos, cuja deposição no meio ambiente pode causar problemas de poluição (18). Assim, a utilização de resíduos agroindustriais na fermentação para obtenção de produtos biotecnológicos tem recebido grande atenção desde então (19).

Uma variedade de microrganismos como os fungos filamentosos são hábeis em degradar o material lignocelulósico do resíduo agrícola (72), utilizando como fonte de carbono para produção de enzimas, especialmente as hidrolíticas (19). Isso ocorre porque as hifas fúngicas invadem o lúmen das células dos materiais lignocelulósicos e produzem diversos metabólitos extracelulares que então agem na degradação da parede celular, entre este metabólitos estão os compostos de baixa massa molecular e as enzimas (91).

A casca do grão da soja é um subproduto obtido do beneficiamento do grão da soja que pode ser usado nos meios fermentativos. Esse resíduo é caracterizado como uma fina camada (tegumento) que recobre o grão. Consiste de uma fonte rica em fibra $36 \%$ (celulose 51,9\%, hemicelulose 10,4\% e lignina 9,4\%), com teor de proteína de cerca de $12 \%(66,92)$. A casca de soja tem destaque no cenário agrícola, em virtude da alta produção brasileira de soja. O Brasil, é considerado o segundo maior produtor mundial de soja (Glycine max), atingindo uma produtividade média de $3.011 \mathrm{~kg} / \mathrm{ha}$. Na safra de 2014/2015 a cultura da soja alcançou a produção de 95,070 milhões de toneladas do grão (93). Dessa forma para cada tonelada de soja processada são produzidos $50 \mathrm{~kg}$ de casca de soja, e apesar de serem empregadas na manufatura da ração animal, uma grande parte deste subproduto é descartado como resíduo no ambiente (66).

A soja é processada de diversas maneiras dando origem a produtos e subprodutos de grande importância, como óleo de soja, tofu, o leite da soja, iogurte à base de soja. Estes alimentos são fonte de isoflavonas, antioxidantes e outros 
componentes que trazem benefício a saúde $(94,95)$. O seu processamento, no entanto, leva a geração de resíduos.

Okara, é o resíduo sólido oriundo do processo de maceração e aquecimento do grão da soja durante a fabricação do leite de soja (extrato líquido da soja) (96). Acredita-se que o extrato aquoso da soja tenha sido elaborado pela primeira vez na China durante o segundo século depois de Cristo. Desde então este extrato líquido foi sendo consumido diariamente em países orientais, gerando quantidades consideráveis de Okara (94).

Cerca de $1,1 \mathrm{~kg}$ de okara fresco (base úmida) é produzido pelo processamento de $1 \mathrm{~kg}$ de grãos de soja adicionado a quantidade padrão de água, para obtenção do extrato aquoso (96). Da desidratação de $1 \mathrm{~kg}$ deste subproduto, são obtidos, aproximadamente, 250 gramas de okara seco (farinha) (94).

No Japão cerca de 700.000 toneladas por ano de okara são produzidas devido principalmente a fabricação de tofu. Parte do okara é utilizado como alimento para animais e o restante é queimado como resíduo ou despejado em aterros. Algumas pesquisas têm se dedicado a dirigir o uso deste subproduto, para o desenvolvimento de outros alimentos transformados, porém a sua utilização como alimento humano, é limitado pelo seu elevado teor de fibra (96).

Assim, uma alternativa para potencial uso desses resíduos seria a sua utilização como fonte de carbono em bioprocessos para obtenção de produtos de maior valor agregado, tais como enzimas e outros metabólitos secundários.

\subsection{PURIFICAÇÃO ENZIMÁTICA}

A diversidade e crescente importância dos produtos biotecnológicos incentivou 0 desenvolvimento dos processos de purificação, e estimulou modificações no desenvolvimento da fonte de biomoléculas com o objetivo de aumentar a resolução na purificação, integrando as etapas de desenvolvimento do processo (97). 
A purificação de produtos biotecnológicos produzidos por microrganismos constitui uma etapa complexa do processo, dadas à diversidade dos meios de cultivo e as variadas características das biomoléculas de interesse. Entre as características dos meios, pode-se citar a elevada proporção de água, a presença de moléculas orgânicas e inorgânicas e os metabólitos distintos da molécula que será purificada. (97). Quando enzimas são produzidas por meio de processos biotecnológicos, o meio de cultivo frequentemente contém outras enzimas e contaminantes, sendo necessárias operações subsequentes de recuperação, purificação e concentração ("downstream processing"), obtendo assim, a enzima quimicamente pura e com o máximo de atividade específica, seja para uso em processos industriais ou para estudos em escala de laboratório (80).

Em relação às características da biomolécula alvo, além da diversidade na composição (aminoácidos, peptídeos) a localização da biomolécula em relação à célula (intracelular e/ou extracelular) influencia no processo de obtenção do produto puro.

Devido a isso as etapas de purificação são tão ou mais desafiantes que o estudo e desenvolvimento da etapa de cultivo, pois não há processos de purificação de aplicação geral. No entanto, conhecer as técnicas de purificação disponíveis, bem como, conhecer as características físico-químicas da molécula a ser purificada e o grau de pureza a ser atingido, podem facilitar a elaboração da estratégia do processo de purificação a ser adotado (98).

Conceitualmente, o processo de purificação pode ser dividido em quatro etapas principais: a) separação de células e seus fragmentos (clarificaçãorompimento de célula, filtração, centrifugação); b) concentração e/ ou purificação de baixa resolução (precipitação, ultrafiltração, extração em sistema de duas fases líquidas), que compreende a separação da molécula alvo, em relação a moléculas com características físico-químicas diferentes; c) purificação de alta resolução (cromatografias), a qual compreende a separação de classes de moléculas com algumas características físico-químicas semelhantes, como as proteínas; d) operações para acondicionamento final do produto (98). 
Os processos cromatográficos fazem parte da etapa de alta resolução também chamada fase de polimento.

Nestes processos, os solutos de um meio líquido são adsorvidos em um leito de material poroso, com posterior remoção por ação de uma fase líquida móvel (eluente). A configuração física geral é de uma fase estacionária (matriz) empacotada em uma coluna, através da qual uma fase móvel é bombeada. $\mathrm{Na}$ cromatografia líquida, os solutos (metabólitos celulares) presentes em um meio líquido, são retidos em um leito de material poroso, por meio do fenômeno de adsorção (química ou física), partição ou exclusão molecular (97).

Os processos cromatográficos são extensamente usados com alto desempenho na etapa de purificação de produtos biotecnológicos. A cromatografia de troca iônica é a técnica mais comumente empregada na separação de proteínas e enzimas, além disso, é utilizada com muita efetividade pelas indústrias bioquímicas e farmacêuticas para o escalonamento dos processos de isolamento de proteínas (99). Este método, baseia-se no princípio da reversibilidade das atrações eletrostáticas de uma molécula carregada em relação a uma matriz sólida com grupos com cargas opostas e ligados covalentemente à matriz $(80,100)$.

Outro método útil na separação de biomoléculas em função da massa molar é a cromatografia de exclusão molecular, também conhecida como filtração em gel. 0 princípio básico desse método é que as moléculas são separadas em função de diferenças no tamanho em uma fase estacionária de porosidade definida. Uma mistura de proteínas dissolvidas em uma solução tampão adequada, flui, através de uma coluna preenchida por esferas microscópicas de material polimérico poroso inerte. As moléculas menores podem penetrar em todos os poros da matriz e, então, mover-se lentamente ao longo da coluna. Dessa forma, as moléculas serão eluídas de acordo com o decréscimo em seus tamanhos, percorrendo a coluna com velocidades diferenciadas (98).

A cromatografia de exclusão molecular pode ser empregada de duas maneiras distintas, na separação de grupos e no fracionamento de alta resolução de biomoléculas. Na separação de grupos, os componentes da amostra são separados em duas populações principais, de acordo com sua faixa de tamanho. Este tipo de 
cromatografia é utilizado na remoção de contaminantes de alta ou baixa massa molares ou na dessalinização. No fracionamento de alta resolução, a amostra é, também, separada de acordo com diferenças nas suas massas molares, podendo ser empregada para isolar monômeros de agregados, para determinar a massa molar ou para efetuar uma análise de distribuição de massas molares (98).

Para projetar um efetivo e seletivo procedimento cromatográfico de separação e purificação é necessário ter conhecimento do efeito das condições operacionais que influenciam na adsorção, como pH, temperatura, concentração da molécula carregada e velocidade do fluxo do processo, de modo a maximizar a purificação sem prejuízos na recuperação (80).

Segundo estudos de purificação de $\beta$-galactosidases fúngicas, diversas técnicas de purificação combinadas são usadas, sendo a maioria de alta resolução utilizando cromatografia de troca iônica. No trabalho de Isobe et al. (2013), uma $\beta$ galactosidase de Therasphaeria acidotherma foi purificada utilizando precipitação com sulfato de amônia, cromatografia de troca iônica, hidrofobicidade e gel filtração (101). Nagy et al. (2001), purificaram $\beta$-galactosidase de Penicillium chrysogenum também por cromatografia de troca iônica e afinidade (42). Widmer et al., (1979) purificaram uma $\beta$-galactosidase de Aspergillus niger com auxílio de cromatografia de troca iônica e de interação hidrofóbica (102). Nath et al., (2015) escreveram em sua revisão sobre $\beta$-galactosidase que a enzima de Aspergillus oryzae foi purificada por Tanaka et al.,(1975), através de técnicas cromatográficas combinadas (47).

A efetivação de cada etapa de purificação muitas vezes, compreende a aplicação de mais de uma operação unitária. Por outro lado, existem produtos cuja aplicação não requer elevado grau de pureza, de modo que operações cromatográficas não são necessárias. Entretanto, em qualquer situação, a redução do número de etapas é de fundamental importância na redução do custo e de perdas da molécula alvo (98). Em muitos processos, os custos com estas operações podem atingir até $80 \%$ dos custos totais de produção (97). 


\section{OBJETIVOS}

Avaliar a capacidade de produção de $\beta$-galactosidase extracelular por fungos filamentosos isolados do cerrado do centro-oeste brasileiro e purificar pelo menos uma $\beta$-galactosidase presente em meio líquido utilizando resíduo agroindustrial da soja como parte do substrato.

Para que o objetivo proposto fosse alcançado, os seguintes objetivos específicos foram estabelecidos:

- Selecionar fungos filamentosos isolados do solo de Brasília (Bioma Cerrado Brasileiro) quanto à capacidade de produção de $\beta$-galactosidase em meio de cultivo utilizando resíduo de soja.

- Avaliar a influência de diferentes fatores físico-químicos como, $\mathrm{pH}$ e temperatura e agitação na produção de $\beta$-galactosidase utilizando planejamento experimental estatístico;

- Produzir e purificar uma $\beta$-galactosidase expressa pelo fungo previamente selecionado como melhor produtor.

- Caracterizar a enzima purificada quanto as suas constantes cinéticas, temperatura ótima, $\mathrm{pH}$ ótimo, termoestabilidade inibição por metais e atividade frente a substratos específicos para $\beta$-galactosidase.

- Testar aplicabilidade industrial da $\beta$-galactosidase purificada. 


\section{MATERIAIS E MÉTODOS}

\subsection{RESÍDUOS AGROINDUSTRIAIS DA SOJA}

\subsubsection{Origem dos resíduos}

A casca da soja bem como os grãos utilizados para a obtenção do extrato liquido da soja (leite de soja) e okara, são provenientes da Fazenda Três Pinheiros, em Planaltina - DF, gentilmente cedidos pelo Dr. Félix Siqueira - Pesquisador da Empresa Brasileira de Pesquisa Agropecuária ( EMBRAPA - Agroenergia).

\subsubsection{Pré-tratamento da casca de soja}

A casca de soja foi autoclavada a $121^{\circ} \mathrm{C}$ por 2 horas, com posterior lavagem em água corrente para retirar sujidades encontradas neste resíduo. Após a lavagem, este material foi seco a $65^{\circ} \mathrm{C}$ por 48 horas em estufa, sendo então triturado em moinho para obtenção de pequenas partículas homogêneas (103).

\subsubsection{Obtenção do extrato líquido da soja (leite de soja) e okara}

Para obtenção do extrato liquido da soja e okara seguiu-se orientações do documento 65 EMBRAPA modificado (14). Foram utilizados $250 \mathrm{~g}$ de grão de soja inteiros, lavados e colocados de molho em água potável por 12 horas, etapa denominada maceração. Após este preparo os grãos foram lavados e submersos em 1 litro de água em ebulição e fervidos por 10 minutos. Em seguida os grãos foram lavados em água corrente, escorridos em tamis e triturados em liquidificador por 3 minutos com 1 litro de água em ebulição. O produto triturado foi filtrado em filtro de tecido de algodão. O líquido filtrado é o extrato de soja (leite de soja), e a massa sólida é chamada de resíduo okara (Figura 2). O resíduo foi seco em estufa à $65^{\circ} \mathrm{C}$ até atingir umidade entre $5-10 \%$, macerado em gral e armazenado em 
temperatura ambiente, enquanto que o extrato liquido foi congelado a $-20^{\circ} \mathrm{C}$ até a sua utilização.

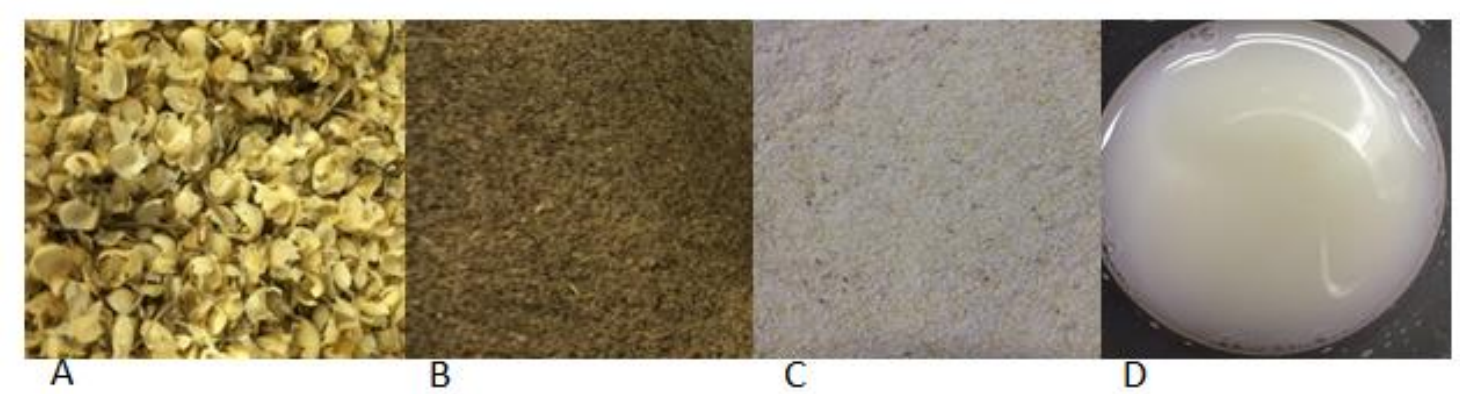

Figura 2 - Resíduos agroindustriais da soja. A. Casca de soja; B. Casca de soja tratada (triturada); C. Okara; D. Extrato líquido da soja.

\subsection{ORIGEM E MANUTENÇÃO DOS FUNGOS FILAMENTOSOS}

Os fungos filamentosos isolados do solo do cerrado centro-oeste brasileiro (Tabela 3), foram obtidos da coleção de microrganismos para Controle de Fitopatógenos e plantas Daninhas da Embrapa Recursos genéticos Biotecnologia, credenciada pelo Conselho de Gestão do Patrimônio Genético (CGEN)- Deliberação número 67 publicada no D.O.U. em 13.09.2004, Seção 1, página 53, vinculada ao projeto intitulado "Aplicação de Holocelulases de Fungos Filamentosos em Processos Biotecnológicos", coordenado pelo Prof. Dr. Edvaldo Ximenes Ferreira Filho, Processo número 010237/2015-1, Universidade de Brasília. Os fungos filamentosos foram preservados a $-80^{\circ} \mathrm{C}$ em criotubo, contendo glicerol $20 \%(\mathrm{v} / \mathrm{v})$. 
Tabela 3 - Fungos filamentosos isolados do solo do bioma cerrado centro-oeste brasileiro, utilizados neste trabalho

\section{Espécies}

Aspergillus flavus

Aspergillus foetidus

Aspergillus sydowii

Aspergillus terreus

Aspergillus versicolor

Fusarium sp.

Fusarium oxysporum

Fusarium semitectum

Fusarium solani

Mucor sp.

Penicillium aurantiogriseum

Penicillium citrino
Penicillium crustosum

Penicillium decumbens

Penicillium felutanum

Penicillium funiculosum

Penicillium glandicola

Penicillium restrictum

Penicillium rugulosum

Penicillium roqueforti

Penicillium variabile

Phaecilomyces lilacinus

Phaecilomyces variotti

Trichoderma sp.

Penicillium corylophilum

\subsection{CONDIÇÕES DE CULTIVO DOS FUNGOS FILAMENTOSOS}

As 25 cepas previamente armazenadas em glicerol a $-80^{\circ} \mathrm{C}$, foram , descongeladas gradativamente e inoculadas em placa de Petri em meio de cultura Batata Dextrose Ágar (BDA) composto de caldo de batata 2,0\% (p/v), dextrose 1,0\% $(\mathrm{p} / \mathrm{v})$ e ágar $2,0 \%(\mathrm{p} / \mathrm{v})$ e incubados a $28^{\circ} \mathrm{C}$ por 7 dias para o crescimento do micélio.

\subsubsection{Meio de cultivo utilizado para triagem}

Os cultivos em condições submersas das cepas reativadas (item 4.3), foram realizados utilizando Erlenmeyer de $250 \mathrm{~mL}$, contendo em cada um $50 \mathrm{~mL}$ de meio liquido mínimo ( $\mathrm{MM})$ com a seguinte composição: (0,4\% peptona, 0,4\% extrato de levedura, 0,2\% $\mathrm{KH}_{2} \mathrm{PO}_{4}, 0,8 \% \mathrm{NaH} 2 \mathrm{PO} 4$ e 0,25\% $\left.\mathrm{MgSO}_{4}\right) \mathrm{pH} 7,0$ (42). Para a 
triagem foi adicionado ao meio mínimo 2,0\% (p/v) de casca de soja, o qual foi denominado MM1.

\subsubsection{Variações dos nutrientes do meio}

Após a triagem, o meio mínimo foi suplementado com $2 \%$ okara (recebendo a denominação de MM2), e $2 \%$ leite de soja (denominado MM3) separadamente como fonte de carbono.

Em seguida, o meio mínimo mais $2 \%$ de casca de soja (MM1) foram suplementados com mais 0,4\% peptona (MM1P), 0,4\% extrato de levedura (MM1E) ou $2 \%$ glicose (MM1G). A mesma suplementação de peptona, extrato de levedura e glicose foi realizada no meio mínimo contendo okara 2\% (MM2) recebendo a denominação respectivamente de MM2P, MM2E, MM2G.

Por fim, o meio mínimo com $2 \%$ de casca de soja foi enriquecido com $2 \%$ lactose (MM1L). Foi realizado também cultivo sem a adição de resíduo, ou seja $100 \%$ meio mínimo, bem como, cultivos contendo somente casca de soja e água sem suplementação (M1). A Figura 3 apresenta as variações na composição dos meios conforme descrito acima.

Todos meios de cultura foram autoclavados a $120^{\circ} \mathrm{C}$ por 20 minutos. 


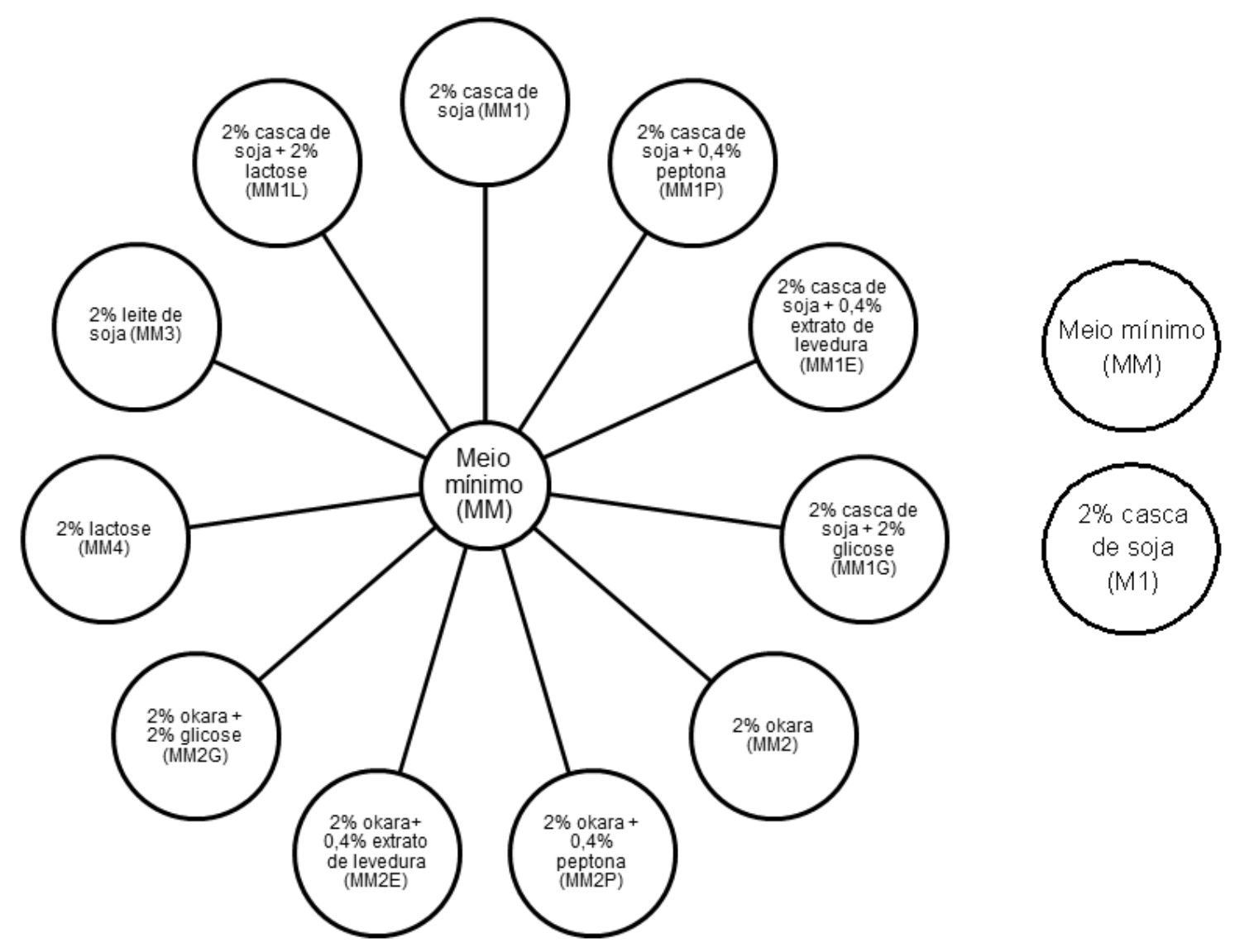

Figura 3 - Esquema das variações dos nutrientes dos meios de cultivo.

\subsubsection{Preparo do inóculo}

O inóculo foi obtido através da raspagem do micélio, crescido em placa de Petri, suspenso em solução esterilizada de $0,9 \% \mathrm{NaCl}$ e Tween 80 até formar uma solução homogênea contendo $10^{7}$ esporos $/ \mathrm{mL}$. Para a contagem dos esporos foi utilizado câmera de Newbauer e microscópio óptico. Uma alíquota $(1 \mathrm{~mL})$ desta suspensão ( $10^{7}$ esporos) foi inoculada em Erlenmeyer contendo $50 \mathrm{~mL}$ de meio liquido, conforme descrito acima. Os cultivos foram realizados por 7 dias a $28^{\circ} \mathrm{C}$ com agitação constante de $120 \mathrm{rpm}$. Os meios de cultura contendo a massa micelial foram filtrados à vácuo em funil de Buchner com papel de filtro (Whatman n¹), centrifugados por 6 minutos a $9000 \mathrm{rpm}$, adicionado azida sódica e armazenado a $20^{\circ} \mathrm{C}$. O caldo fermentado filtrado, denominado extrato bruto (EB), foi usado para o ensaio da determinação da atividade enzimática da $\beta$-galactosidase e quantificação de proteína total. 


\subsection{DETERMINAÇÃO DA ATIVIDADE ENZIMÁTICA}

O ensaio para a determinação da atividade enzimática da $\beta$-galactosidase foi baseado em Nagy et al., (2001) (42). Uma alíquota do caldo fermentado ou extrato bruto $(0,5 \mathrm{~mL})$ foi incubada com o substrato $(0,5 \mathrm{~mL}$ de Ortho-nitrophenol- $\beta$ - $D$ galactopiranosideo - ONPG (Sigma-Aldrich - USA), $3 \mathrm{mM}$, diluído em tampão fosfato de sódio $0,1 \mathrm{M}, \mathrm{pH} 7,0$ ) por 30 minutos a $30^{\circ} \mathrm{C}$. Foi utilizado como solução de parada $2 \mathrm{~mL}$ de $\mathrm{Na}_{2} \mathrm{CO}_{3}$ a $0,1 \mathrm{M}$. A leitura da absorbância foi realizada em espectrofotômetro (Shimadzu Spectrophotometer UV-1800) utilizando comprimento de onda de 410nm. Para eliminação de interferentes cromógenos na quantificação enzimática, foi feito um branco do substrato, onde substituiu-se o volume da enzima pelo tampão fosfato de sódio $0,1 \mathrm{M} \mathrm{pH} \mathrm{7,0.} \mathrm{Também} \mathrm{foi} \mathrm{feito} \mathrm{o} \mathrm{branco} \mathrm{da} \mathrm{enzima} \mathrm{onde} \mathrm{substituiu-se} \mathrm{o}$ volume do substrato pelo mesmo tampão já citado.

A curva padrão foi construída com solução de ortho-nitrophenol (SigmaAldrich) em diferentes concentrações, 9,37 $\mu \mathrm{mol} ; 18,75 \mu \mathrm{mol} ; 37,5 \mu \mathrm{mol} ; 75 \mu \mathrm{mol}$; $150 \mu \mathrm{mol} ; 300 \mu \mathrm{mol}$. Uma unidade de atividade enzimática de $\beta$-galactosidase foi definida como a quantidade de enzima capaz de catalisar a liberação de $1 \mu \mathrm{mol}$ de O-nitrophenol por minuto.

\subsection{QUANTIFICAÇÃO DE PROTEÍNAS TOTAIS}

A concentração de proteínas totais foi determinada pelo método de Bradford (104). Uma alíquota de $0,1 \mathrm{~mL}$ de amostra foi adicionada a $1,0 \mathrm{~mL}$ do reagente de Bradford. Após 5 minutos, a leitura da absorbância foi realizada em espectrofotômetro (Shimadzu Spectrophotometer, UV-1800) a $595 \mathrm{~nm}$. Para os cálculos da concentração de proteína, foi preparada uma curva padrão utilizando a albumina bovina sérica como padrão $(0-0,3 \mathrm{mg} / \mathrm{mL})$. Todos os ensaios foram realizados em triplicata. 


\subsection{CURVA DE INDUÇÃO ENZIMÁTICA}

A curva de indução enzimática foi determinada pela produção de $\beta$ galactosidase pelo Aspergillus foetidus em meio contendo $2 \%$ de casca de soja, mensurada a cada 24 horas durante um período de 20 dias. $O$ cultivo foi realizado em triplicata como descrito no item 4.3.1. A atividade enzimática da $\beta$-galactosidase e proteína total foram determinadas conforme item 4.4 e 4.5 , respectivamente. $\mathrm{O} \mathrm{pH}$ do meio também foi avaliado a cada amostra. Uma segunda curva de 10 dias foi realizada variando o pH inicial do meio objetivando a redução no tempo de cultivo.

\subsection{DELINEAMENTO EXPERIMENTAL - INFLUÊNCIA DA AGITAÇÃO, PH E TEMPERATURA NA PRODUÇÃO ENZIMÁTICA}

Um delineamento experimental fatorial $2^{3}$, com repetição de três ensaios no ponto central foi empregado para avaliar a influência das variáveis independentes, agitação $(\mathrm{A})$ temperatura de incubação $(\mathrm{T})$ e $\mathrm{pH}$ inicial do meio, sobre a produção da $\beta$-galactosidase por Aspergillus foetidus em casca de soja $2 \%$.

Os níveis superiores $(+1)$ e inferiores $(-1)$ dos fatores estudados foram, agitação (100-140 rpm), temperatura $\left(22-34^{\circ} \mathrm{C}\right)$ e $\mathrm{pH}$ inicial do meio (5-9), respectivamente. Os valores do ponto central (0) em triplicata foram $120 \mathrm{rpm}, 28^{\circ} \mathrm{C} \mathrm{e}$ $\mathrm{pH} \mathrm{7,0} \mathrm{(Tabela} \mathrm{4).} \mathrm{No} \mathrm{total} \mathrm{foram} \mathrm{realizados} 11$ ensaios que estão representados na Tabela 5. 
Tabela 4 - Níveis e valores das variáveis independentes do processo experimental para o estudo da produção $\beta$-galactosidase sob influência de diferentes valores de $\mathrm{pH}$, temperatura e agitação.

\begin{tabular}{ccccc}
\hline $\begin{array}{c}\text { Variáveis } \\
\text { independentes }\end{array}$ & Símbolos & \multicolumn{3}{c}{ Níveis e valores } \\
\hline Agitação $(\mathrm{rpm})$ & $\mathrm{X}_{1}$ & 100 & 120 & 140 \\
Temperatura $\left({ }^{\circ} \mathrm{C}\right)$ & $\mathrm{X}_{2}$ & 22 & 28 & 34 \\
$\mathrm{pH}$ & $\mathrm{X}_{3}$ & 5 & 7 & 9 \\
\hline
\end{tabular}

$X_{1}=$ Agitação $(r p m), X_{2}=$ Temperatura, $X_{3}=p H$

Tabela 5 - Matriz do planejamento fatorial $2^{3}$ com ponto central em triplicata para produção de $\beta$ galactosidase

\begin{tabular}{lllllll}
\hline \multirow{2}{*}{ Ensaio } & \multicolumn{3}{c}{ Variáveis codificadas } & \multicolumn{3}{l}{ Variáveis reais } \\
\cline { 2 - 6 } & $\mathrm{X} 1$ & $\mathrm{X} 2$ & $\mathrm{X} 3$ & $\mathrm{~A}(\mathrm{rpm})$ & $\mathrm{T}\left({ }^{\circ} \mathrm{C}\right)$ & $\mathrm{pH}$ \\
\hline 1 & -1 & -1 & -1 & 100 & 22 & 5 \\
2 & +1 & -1 & -1 & 140 & 22 & 5 \\
3 & -1 & +1 & -1 & 100 & 34 & 5 \\
4 & +1 & +1 & -1 & 140 & 34 & 5 \\
5 & -1 & -1 & +1 & 100 & 22 & 9 \\
6 & +1 & -1 & +1 & 140 & 22 & 9 \\
7 & -1 & +1 & +1 & 100 & 34 & 9 \\
8 & +1 & +1 & +1 & 140 & 34 & 9 \\
9 & 0 & 0 & 0 & 120 & 28 & 7 \\
10 & 0 & 0 & 0 & 120 & 28 & 7 \\
11 & 0 & 0 & 0 & 120 & 28 & 7 \\
\hline
\end{tabular}

X1 = Agitação, $\mathrm{X} 2$ = Temperatura e X3 = pH

A análise dos dados do delineamento experimental foi realizada por meio de análise de variância (ANOVA), a um nível de significância $p \leq 0,05$ e a extensão da variância explicada por cada modelo foi dada pelo coeficiente de determinação, $R^{2}$. 
Utilizou-se, o planejamento fatorial fracionado em dois níveis, onde cada fator assume um valor máximo e um mínimo. O Software Design Expert ${ }^{\circledR}$ 9.0, foi utilizado para a regressão e análise gráfica dos dados.

\subsection{PURIFICAÇÃO DA BETA-GALACTOSIDASE}

\subsubsection{Ultrafiltração}

O extrato bruto (EB), obtido após cultivo do fungo por 7 dias em casca de soja, foi concentrado dez vezes pelo processo de ultra filtração utilizando membrana de exclusão molecular de 100 kilo Daltons $(\mathrm{kDa})$, em sistema de ultrafiltração Amicon (Amicon Milipore Inc., Beverly, MA, 01915, USA) a pressão controlada e a temperatura média de aproximadamente $10^{\circ} \mathrm{C}$ em câmera fria. Alíquotas do ultrafiltrado foram novamente concentradas aproximadamente 10 vezes, pelo mesmo sistema, com uma membrana de exclusão molecular de $30 \mathrm{kDa}$. Foram obtidas duas frações: concentrado e ultrafiltrado.

\subsubsection{Cromatografia}

Para esta etapa de purificação foram utilizadas cromatografias em coluna de gel filtração e troca iônica. As frações foram analisadas quanto a atividade enzimática da $\beta$-galactosidase e a concentração proteica. As frações com atividades para $\beta$-galactosidase foram agrupadas. Todas as colunas utilizadas estavam acopladas ao sistema de purificação Akta pure (GE Healthcare Life Sciences, Uppsala Sweden) e equilibradas com soluções tampão previamente definidos.

\subsubsection{Cromatografia de gel filtração - Sephacryl S-200 HR}

Uma amostra de $5 \mathrm{~mL}$ do extrato concentrado da fração $>30 \mathrm{kDa}$ foi aplicada em coluna Sephacryl S-200 $(16 \mathrm{~cm} \times 60 \mathrm{~cm})$ previamente equilibrada com tampão fosfato de sódio $0,1 \mathrm{M} \mathrm{pH} \mathrm{7,0.} \mathrm{A} \mathrm{amostra} \mathrm{eluída} \mathrm{com} \mathrm{fluxo} \mathrm{fixo} \mathrm{de} 0,5 \mathrm{~mL} / \mathrm{min}$ foi 
coletada em frações de $2 \mathrm{~mL}$. A atividade enzimática foi determinada para cada fração conforme item 3.4 e as frações contendo atividade para $\beta$-galactosidase foram reunidas (denominadas Pico 1 S-200) e submetidas a cromatografia de troca iônica, após ser concentrada 5 vezes por liofilização.

\subsubsection{Cromatografia de troca iônica - DEAE FF}

Uma alíquota de $1 \mathrm{~mL}$ da amostra Pico 1 S-200, foi aplicada em uma coluna de troca iônica aniônica de Dietilaminoetil Fast Flow (DEAE FF - GE Healthcare Biosciences de $1 \mathrm{~mL}$ ), previamente equilibrada nas mesmas condições da coluna $S$ 200. A eluição foi iniciada com tampão fosfato de sódio $0,1 \mathrm{M} \mathrm{pH} \mathrm{7,0} \mathrm{a} \mathrm{um} \mathrm{fluxo} \mathrm{de}$ 0,250 $\mathrm{mL} / \mathrm{min}$, seguido a um gradiente linear de cloreto de sódio $(0,0-1,0 \mathrm{M})$. Frações de $1 \mathrm{~mL}$ foram coletadas e analisadas, quanto a atividade e a presença de proteínas. As frações com atividades para $\beta$-galactosidase (denominadas Pico 1 DEAE) foram submetidas a análise por eletroforese (SDS-PAGE) afim de avaliar o grau de pureza da amostra. O mesmo procedimento foi repetido com o eluente tampão fosfato acima citado, porém em pH 8,0.

As etapas utilizadas na purificação da $\beta$-galactosidase estão representadas na Figura 4. 


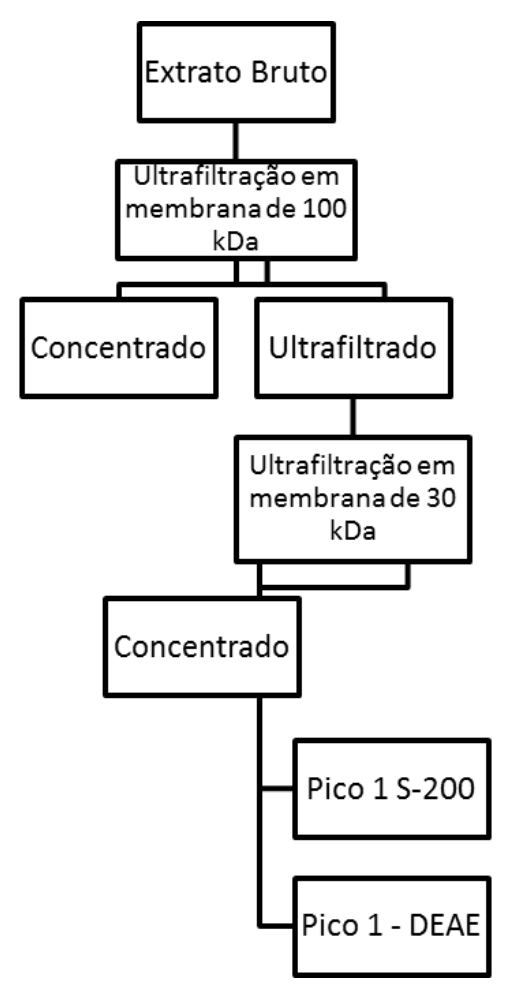

Figura 4 - Esquema simplificado da metodologia de purificação da $\beta$-galactosidase de Aspergillus foetidus.

\subsection{ELETROFORESE}

\subsubsection{Eletroforese em gel de poliacrilamida (SDS-PAGE)}

O grau de pureza das amostras enzimáticas (extrato bruto, $<100,>30$, pico 1 S-200, e pico 1- DEAE), foi analisado por eletroforese em gel de poliacrilamida $10 \%$ sob condições desnaturantes com dodecilsulfato de sódio (SDS-PGE), conforme descrito por Laemmli, (1970) (105). Géis de poliacrilamida foram formados por copolimerização de acrilamida e Bis-acrilamida na presença de persulfato de amônio (APS) e tetrametiletilenodiamina (TEMED). O gel concentrador foi preparado a $5 \%$ $(\mathrm{v} / \mathrm{v})$.

As amostras contendo aproximadamente $100 \mu \mathrm{g}$ de proteína foram precipitadas com Ácido Tricloroácetico (TCA) 10\% e incubadas por 30 minutos a $4^{\circ} \mathrm{C}$. Posteriormente as amostras foram centrifugadas $14000 \mathrm{rpm}$ a $4^{\circ} \mathrm{C}$ por 15 minutos. Em seguida o sobrenadante foi descartado e o concentrado foi lavado com 
acetona fria por 3 vezes seguido de centrifugações conforme descrito anteriormente. As amostras permaneceram à temperatura ambiente por 3 minutos para secagem. $O$ pellet formado foi ressuspendido em $20 \mu \mathrm{L}$ de tampão de amostra (Tris- $\mathrm{HCl} 125 \mathrm{mM}$ $\mathrm{pH}$ 6,8; SDS 2\%; azul de bromofenol 0,5\%; glicerol $20 \%$ e $\beta$-mercaptanol 5\%) e fervidas por 3 minutos a $100^{\circ} \mathrm{C}$. Uma alíquota de $15 \mu \mathrm{L}$ das amostras concentradas foi aplicada no gel de poliacrilamida 10\%. A eletroforese foi realizada em sistema cuba vertical (miniVE- GE Healthcare Life Science) com tampão de corrida (Tris-HCl $125 \mathrm{mM}$, glicina $192 \mathrm{mM}$ e SDS 0,1\% (v/v), $\mathrm{pH} 8,3)$ a temperatura ambiente e com voltagem constante de $13 \mathrm{~mA}$. Foram utilizados como marcador de massa molecular kit de baixo peso molecular (Low Molecular Weight GE Healthcare) contendo as proteínas fosforilase b (97 kDa), soroalbumina bovina (66 kDa), ovoalbumina (45 kDa), anidrase carbônica (30 kDa), inibidor de treipsina (30,1 kDa) e a-lactalbumina $(14,4 \mathrm{kDa})$. E kit de alto peso molecular (High Molecular Weight Marker, GE Healthcare): miosina (220 kDa), a-2 macroglobulina (170 kDa), $\beta$-galactosidase (116 $\mathrm{kDa})$, transferrina $(76 \mathrm{kDa})$ e glutamato desidrogenase (53 kDa). Os géis foram corados com azul de Comassie.

\subsubsection{Coloração com azul de Comassie}

As bandas proteicas presentes no SDS-PAGE foram visualizadas após a sua incubação por 12 horas à temperatura ambiente, em 0,1 g de azul de Comassie dissolvido em solução fixadora $(45 \mathrm{~mL}$ de metanol, $10 \mathrm{~mL}$ de ácido acético glacial e $45 \mathrm{~mL}$ de água destilada). Após o tempo de incubação na solução corante, o gel foi descorado utilizando a solução fixadora.

\subsubsection{Zimograma}

O gel de poliacrilamida foi preparado como descrito nos itens 4.9.1. Para a determinação da atividade de $\beta$-galactosidase no gel a fração mais pura (Pico 1 DEAE) da enzima foi colocada em contato com $20 \mu \mathrm{L}$ de tampão de amostra sem $\beta$ mercaptanol e sem serem submetidas à fervura. Após a corrida o gel foi incubado em uma solução de 5-bromo-4-cloro-indolil- $\beta$-D-galactopiranosidio (X-GAL) 0,02\% 
(p/v) (7) e tampão fosfato $0,1 \mathrm{M}$ pH 7,0 por 12 horas. A hidrólise do substrato cromogênico $X$-Gal pela enzima $\beta$-galactosidase libera a fração cromogênica que está ligada ao açúcar presente no composto formando bandas azuis no gel de poliacrilamida (39).

\subsubsection{Determinação da massa molar}

As massas molares das proteínas foram estimadas pelo comprimento das bandas no SDS-PAGE (item 4.9.1), utilizando o gráfico dos logaritmos das massas molares (log PM) das proteínas padrões pelas suas respectivas mobilidades eletroforéticas $(\mathrm{cm})$. Foram utilizados os padrões do kit de alto peso molecular (Molar weight marker kit- HMW).

A coluna de gel filtração foi calibrada com os padrões de massa molar conhecida aldolase (158 kDa), conalbumina (75 kDa), ovoalbumina (44 kDa), anidrase carbônica $(29 \mathrm{kDa})$ e ribonuclease $A(13,7 \mathrm{kDa})$. O volume de exclusão (Vo) foi estimado pelo volume de eluição do azul dextran 2000. Os volumes de eluição (Ve) de cada padrão foram determinados durante a eluição e o Kav das proteínas padrões foram calculados. A massa molecular da enzima foi então calculada através do gráfico do log das massas molares (Mr) versus o kav das proteínas padrões.

\subsection{CARACTERIZAÇÃO BIOQUÍMICA DA BETA-GALACTOSIDASE}

\subsubsection{Efeito do $\mathrm{pH}$}

Para determinar o efeito do $\mathrm{pH}$ na atividade de $\beta$-galactosidase, as amostras do extrato bruto e da enzima parcialmente purificada (Pico1-DEAE) foram avaliadas na presença de soluções tampões em diferentes valores de $\mathrm{pH}$ no intervalo de 1,0 9,0. O pH ótimo da enzima foi determinado pela incubação da enzima com substrato ONPG (3 mM) diluído em tampão acetato de sódio $50 \mathrm{mM}(\mathrm{pH} \mathrm{2,0} \mathrm{-} \mathrm{6,0),} \mathrm{fosfato} \mathrm{de}$ sódio 50mM (pH 7,0 - 9,0) e cloreto de potássio - ácido clorídrico $(\mathrm{pH} \mathrm{1,0} \mathrm{-} \mathrm{1,5)}$ 
durante 30 minutos. A atividade foi quantificada conforme previamente descrito no item 4.4. O resultado do ensaio do efeito de $\mathrm{pH}$ foi expresso em atividade relativa, sendo que o valor de $100 \%$ de atividade é correspondente ao $\mathrm{pH}$ de maior atividade.

\subsubsection{Efeito da temperatura}

A temperatura ótima da $\beta$-galactosidase do extrato bruto e da amostra parcialmente purificada (Pico 1-DEAE) foi determinada nas temperaturas de 4, 10, $15,20,30,40,50,60,70$, e $80^{\circ} \mathrm{C}$ por 30 minutos. Considerando os resultados obtidos na avaliação do $\mathrm{pH}$ ótimo, este ensaio de temperatura ótima foi realizado em $\mathrm{pH}$ 2,0 para o extrato bruto e $\mathrm{pH} \mathrm{3,0} \mathrm{para} \mathrm{enzima} \mathrm{pura.} \mathrm{A} \mathrm{atividade} \mathrm{enzimática} \mathrm{foi}$ avaliada de acordo com item 4.4.

\subsubsection{Termoestabilidade}

A estabilidade térmica da $\beta$-galactosidase foi avaliada a $4^{\circ} \mathrm{C}, 50^{\circ} \mathrm{C}$ e $70^{\circ} \mathrm{C}$. A amostra contendo a enzima parcialmente pura foi incubada nas temperaturas acima citadas, em tampão $\mathrm{pH} \mathrm{3,0} \mathrm{por} 20$ horas. A atividade enzimática residual foi determinada a cada 60 minutos. Após cada tempo, a amostra incubada foi retirada para realizar o ensaio enzimático conforme descrito no 4.4 .

\subsubsection{Efeitos de íons metálicos}

Para avaliar o efeito dos íons metálicos e do ácido etilenodiamino tetraacético (EDTA) na atividade enzimática, a enzima foi incubada com os íons $\mathrm{Ag}^{+}, \mathrm{K}^{+}$, $\mathrm{Na}^{+}, \mathrm{Ca}^{2+}, \mathrm{Cu}^{2+}, \mathrm{Fe}^{2+}, \mathrm{Mg}^{2+}, \mathrm{Zn}^{2+}, \mathrm{Al}^{3^{+}}, \mathrm{Fe}^{3^{+}}$e EDTA, separadamente em concentrações de $1 \mathrm{mM}$ e $10 \mathrm{mM}$ por 20 minutos a $30^{\circ} \mathrm{C}$. A atividade residual da $\beta$ galactosidase foi quantificada conforme descrito item 4.4 e os desvios-padrão foram calculados como percentuais da média para o ensaio correspondente. A atividade foi expressa como atividade relativa, sendo que o valor de $100 \%$ de atividade correspondeu à atividade realizada na ausência de íons metálicos. 


\subsubsection{Especificidade ao substrato}

O estudo da especificidade da $\beta$-galactosidase da fração Pico 1-DEAE foi realizado determinando a atividade enzimática após incubar a enzima em diferentes substratos e foi expresso em porcentagem de atividade em relação à máxima atividade detectada. Foram utilizadas como substrato para-nitrofenil-B-D glicopiranosideo (pNPG) lactose 5\%, ortho-nitrofenil-b-d glicopiranosideo (ONPG) 3 $\mathrm{mM}$ e carboxi metil celulose $1 \%(\mathrm{CMC})$.

\subsubsection{Determinação de parâmetros cinéticos}

Para a determinação da constante de Michaelis-Mentem (Km) e da velocidade máxima (Vmáx) foram realizados ensaios com concentrações de substrato (ONPG) variando de $1 \mathrm{mM}$ a $50 \mathrm{mM}$. Para o substrato lactose as concentrações variaram de $1 \mathrm{mM}$ a $300 \mathrm{mM}$. Os ensaios de atividade foram realizados conforme item 4.4. A análise dos resultados para os parâmetros cinéticos foi determinada pelo programa Enzifitter (106).

\subsection{APLICABILIDADE DA BETA-GALACTOSIDASE}

\subsubsection{Hidrólise da lactose no leite}

O substrato utilizado para a realização deste ensaio foi a lactose presente no leite Molico ${ }^{\circledR}$ (Nestlé).

O teste de hidrólise da lactose para fins didáticos foi dividido em três etapas:

1) Quantificação da lactose da amostra a ser testada: A quantificação de açúcar redutor, lactose, no leite foi realizada utilizando o método do ácido 3-5'dinitrosalicílico (DNS) (107). Preparou-se uma solução de $100 \mathrm{mg}$ de leite em pó desnatado Molico ${ }^{\circledR}$ diluído em $1 \mathrm{~mL}$ de água destilada para quantificar a amostra. Para conhecer a concentração de lactose da amostra, adicionou-se $150 \mu \mathrm{L}$ dessa solução a $300 \mu \mathrm{L}$ do reagente de DNS. Essa mistura foi incubada em banho-maria a 
$100^{\circ} \mathrm{C}$ por 10 minutos. Após resfriamento (aproximadamente 3 minutos) à temperatura ambiente, foram adicionadas mais $1,5 \mathrm{~mL}$ de água destilada à mistura. A mistura foi agitada vigorosamente para homogeneização da cor e a leitura foi feita a 540nm (107). A curva de calibração foi realizada com lactose (Vetec® Química Fina LTDA) como padrão. A amostra contendo $100 \mathrm{mg} / \mathrm{mL}$ de leite resultou em $63 \%$ de lactose. Em seguida preparou-se uma solução do leite contendo 5\% de lactose. A concentração contendo $5 \%$ lactose é a quantidade normalmente encontrada em leite bovino (30). A metodologia do DNS para a detecção da lactose também foi usada por Silveira Bizelli (2010) (108).

2) Quantificação da conversão de lactose em glicose: Para a determinação da conversão da lactose em glicose pela enzima $\beta$-galactosidase a metodologia usada foi adaptada de Matioli et al. (2003). Foram incubados $50 \mu \mathrm{L}$ da amostra Pico 1DEAE em diferentes concentrações ( 0 a $4,54 \mathrm{UI} / \mathrm{mL}$ ) com 2,5mL de leite com lactose $5 \%$ a $50^{\circ} \mathrm{C}$ durante 30 minutos (52). Foi realizado o branco da amostra onde incubou-se apenas o leite e tampão. Transcorrido o tempo de reação, foram coletados $150 \mu \mathrm{L}$ da amostra incubada e adicionados $300 \mu \mathrm{L}$ de DNS. O DNS detecta a quantidade de açúcar redutor liberada durante o ensaio. As soluções com o reagente foram incubadas a $100^{\circ} \mathrm{C}$ durante 10 minutos. Ao final, $1,5 \mathrm{~mL}$ de água destilada foram adicionados e a leitura da absorbância foi realizada em espectrofotômetro a 540nm (Shimadzu). A atividade hidrolítica foi expressa como 1 $\mu \mathrm{mol}$ de açúcar redutor formado por minuto (Unidade Internacional - UI) por $1 \mathrm{~mL}$ de enzima (UI. $\mathrm{mL}^{-1}$ ). Todos os ensaios foram realizados em triplicata. A curva padrão foi determinada com D-glicose (Vetec® Química Fina LTDA).

\subsubsection{Estabilidade da enzima em condições de simulação gástrica.}

A estabilidade da enzima em condições simuladas de $\mathrm{pH}$ gástrico, foi realizada utilizando a metodologia de O'Connel et al. (2008) (7) . Realizou-se a incubação de $5 \mathrm{~mL}$ da enzima com $5 \mathrm{~mL}$ de Fluído Gástrico Simulado (SGF) pH 2,0 durante $2 \mathrm{~h}$ a $37^{\circ} \mathrm{C}$ e $150 \mathrm{rpm}$. O SGF foi preparado conforme Farmacopeia Brasileira, composto por uma solução de 0,2\% (p/v) de $\mathrm{NaCl}, 0,32 \%(p / v)$ pepsina bovina purificada (Sigma-Aldrich-USA) e $7 \%$ de $\mathrm{HCl}$ (109). Foi realizado 
simultaneamente um controle incubando tampão $\mathrm{pH}$ 2,0 com a enzima e um branco do substrato contendo tampão e SGF.

\subsubsection{Análise estatística}

As amostras foram analisadas em triplicata e os resultados obtidos foram apresentados na forma de média ponderada, com os respectivos desvios padrão. As análises estatísticas foram feitas utilizando o software estatístico GraphPad prism versão 5.0 para Windows (GraphPad Software, San Diego California USA). Os valores encontrados foram comparados ao controle com o uso de um teste da ANOVA de uma via, seguido pelo teste de Tukey. Os testes buscam identificar se as médias encontradas para a amostra e para o controle são significativamente diferentes. O limite de significância para todas as análises estatísticas foi de $p<0,05$, resultando, portanto em um intervalo de confiança de $95 \%$. 


\section{RESULTADOS E DISCUSSÃO}

\subsection{SELEÇÃO DE FUngOS FILAMENTOSOS PRODUTORES DE BETA- GALACTOSIDASE}

A escolha da linhagem microbiana é um dos primeiros passos para a concepção de um bioprocesso promissor (110). Deve ser dotada de algumas características como boa produtividade, constância fisiológica, fácil cultivo e manutenção $(111,112)$.

Fungos filamentosos, na sua grande maioria, fazem parte do grupo de microrganismo que contemplam as características desejadas para um processo fermentativo. São dotados de uma variedade morfológica e bioquímica que lhes conferem uma flexibilidade metabólica com potencial para a síntese de substâncias de interesse industrial em larga escala $(67,110)$.

Sabe-se que o cultivo submerso de microrganismo, dessa classe, é um sistema capaz de gerar uma variedade de metabólitos ativos como as enzimas (113). Estudos demonstram que fungos filamentosos foram eficientes em expressar enzimas quando cultivados em meio líquido contendo resíduos agroindustriais, como a casca de soja $(66,92)$.

Neste estudo 25 cepas de fungos filamentosos foram selecionadas para avaliação da produção de $\beta$-galactosidase. A atividade enzimática de todos os fungos está representada na Figura 5. Nove das 25 cepas apresentaram atividade maior que $1 \mathrm{UI} / \mathrm{mL}$ para a enzima de interesse. Estas atividades variaram de 1,46 $\mathrm{UI} / \mathrm{mL}$ a 26,8 Ul/mL, quando cultivadas em meio mínimo adicionado de casca de soja (Figura 5). 


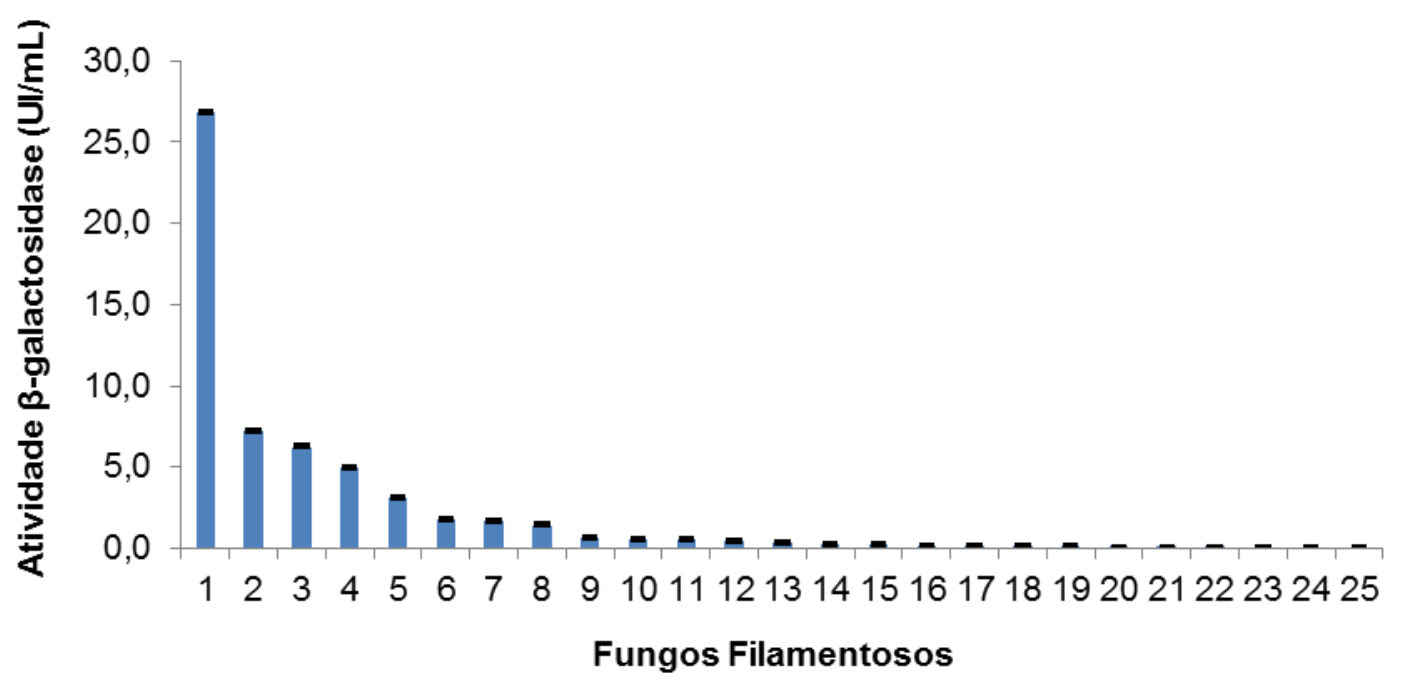

Figura 5 - Triagem dos fungos filamentosos isolados do solo do cerrado frente a capacidade de produzir a enzima $\beta$-galactosidase em casca de soja complementado com meio mínimo. Cultivo realizado por 7 dias $120 \mathrm{rpm}$ à $28^{\circ} \mathrm{C}$.

1. Aspergillus foetidus; 2. Penicillium felutanum; 3. Penicillium variabile; 4. Aspergillus flavus; 5. Penicillium restrictum; 6. Penicillium citrino; 7. Penicillium decumbens; 8. Phaecilomyces lilacinus; 9. Fusarium solani; 10. Aspergillus terreus; 11. Penicillium rugulosum; 12. Penicillium funiculosum; 13. Fusarium semitectum; 14. Penicillium crustosum; 15. Penicillium glandicola; 16. Penicillium corylophilum; 17. Penicillium roqueforti; 18. Penicillium aurantiogriseum; 19.Mucor sp; 20.Aspergillus sydowii; 21. Fusarium oxysporum; 22. Fusarium sp; 23. Aspergillus versicolor; 24. Phaecilomyces variotti; 25. Trichoderma sp.

Dentre os fungos avaliados, os três melhores produtores da enzima foram Aspergillus foetidus (n.1), Penicillium felutanum (n.2) e Penicillium variabile (n.3). Assim, estes foram os fungos selecionados para os ensaios seguintes. Ressalta-se que o fungo n.1 apresentou maior atividade enzimática $(26,8 \mathrm{Ul} / \mathrm{mL})$ quando comparado com os demais microrganismos, sendo sua atividade aproximadamente $70 \%$ superior ao fungo n.2 (7,2 Ul/mL) e n.3 $(6,2 \mathrm{UI} / \mathrm{mL})$.

Os resultados encontrados de atividade enzimática da $\beta$-galactosidase neste trabalho foram semelhantes com os obtidos por outros pesquisadores. Andrades (2014) estudou a produção enzimática extracelular e intracelular de $\beta$-galactosidase por diferentes fungos isolados da Mata Atlântica em diferentes resíduos agroindustriais. Para o fungo Gliocadium virens a enzima extracelular obteve uma 
atividade de 8,47 Ul/mL em casca de laranja. Entretanto, o nível de atividade da $\beta$ galactosidase intracelular foi maior que as extracelulares, como para Gliocadium virens em palha de arroz $(22,57 \mathrm{UI} / \mathrm{mL})$, Crysonilia sithophila em palha de sorgo $(16,48 \mathrm{UI} / \mathrm{mL})$, Aspergillus fumigatus $(17,26 \mathrm{UI} / \mathrm{mL})$, Trichoderma longibiachiatum (17,53 Ul/mL) em casca de arroz e Aspergillus aculeatus cultivado em resíduo de casca de laranja $(56,31 \mathrm{UI} / \mathrm{mL})$ (114). Braga et.al, (2012), avaliaram a produção de enzima $\beta$-galactolítica de Kluyveromyces marxianus cultivado em meio contendo efluentes de arroz onde obteve atividade de 10,4 Ul/mL (115). Nagy et al. (2001) através da fermentação de Penicillium chrysogenum em meio contendo lactose $2 \%$ obtiveram atividade enzimática de 14,31Ul/mL (42). Chuming Nie et.al (2013), conseguiram produzir maiores atividades de $\beta$-galactosidase de $24,5 \mathrm{UI} / \mathrm{mL}$ e 31 $\mathrm{UI} / \mathrm{mL}$ através de sistemas recombinantes de lactobacilos em Pichia pastoris (38).

\subsection{AVALIAÇÃO DA PRODUÇÃO DE BETA-GALACTOSIDASE}

A escolha de um substrato adequado também é importante para a viabilidade do processo fermentativo. $O$ meio de cultivo pode direcionar as vias metabólicas resultando em possíveis alterações de rendimento. Por isso, é fundamental que o substrato favoreça a produtividade, provoque pouca repressão catabólica e que não interfira na estabilidade da enzima secretada (88).

Após a triagem com casca de soja, o Aspergillus foetidus, melhor produtor de $\beta$-galactosidase, foi investigado quanto a sua habilidade em produzir esta enzima em meio líquido contendo outros resíduos derivados da soja e seu beneficiamento, entre eles, okara e extrato líquido da soja (leite de soja).

Objetivando um meio de cultivo ainda mais econômico, foi realizado ensaio sem adição do meio mínimo (MM), descrito item 4.3.2, contendo somente casca de soja. 


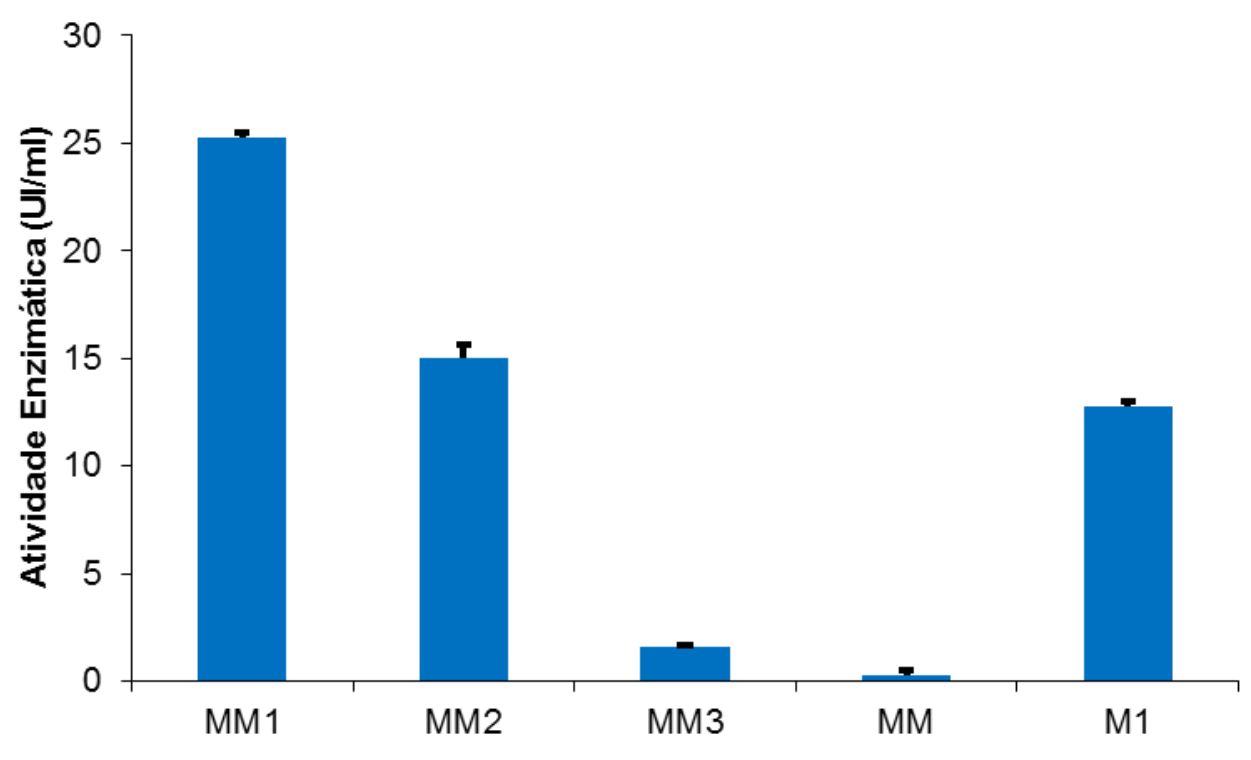

Figura 6 - Atividade enzimática de Aspergillus foetidus cultivado (7 dias, $120 \mathrm{rpm}, 28^{\circ} \mathrm{C}$ ) em diferentes subprodutos de soja. MM1- Meio mínimo + casca de soja; MM2- Meio mínimo + okara; MM3- Meio mínimo + extrato líquido da soja; M3- Meio com leite de soja s/ meio mínimo; MM- meio mínimo; M1- meio casca de soja sem meio mínimo.

Observou-se que o meio mínimo com $2 \%$ de casca de soja (MM1) foi mais favorável para expressão de $\beta$-galactosidase, apresentando uma atividade aproximadamente, $40 \%$ maior quando comparada com o meio contendo okara $2 \%$ (MM2). Outro dado interessante do ensaio, é que o cultivo do fungo em meio contendo somente casca de soja $2 \%$ (M1) apresentou atividade 50\% menor em comparação com o mesmo meio enriquecido com o meio mínimo (MM1). Esse dado mostra a influência positiva que a casca de soja exerce sobre a expressão da $\beta$ galactosidase. Provavelmente a casca de soja contém oligômeros capazes de induzir o crescimento microbiano e a produção enzimática de uma forma independente a suplementação do meio semi-sintético. No trabalho de Tavares (1998), a expressão da enzima ribonuclease por Penicillium citrinum cultivado em meio com resíduos industriais de suco de laranja foi similar a este resultado mostrando uma similaridade no perfil de indução enzimática frente a complementação dos micronutrientes do meio mínimo (116).

Por outro lado, nos substratos com partículas de tamanho menores há a possibilidade da absorção pelo fungo ser facilitada sem a necessidade de dispor da 
síntese de enzimas no meio extracelular. Esse fato pode explicar a menor atividade de $\beta$-galactosidase em meio contendo extrato líquido da soja quando comparado com a casca do grão da soja.

Diante deste resultado, os resíduos escolhidos para a etapa seguinte foram a casca de soja e o okara, ambos suplementados com MM. Foi avaliada a interferência dessas fontes de carbono na produção enzimáticas pelos três fungos, Aspergillus foetidus, Penicillium felutanum, Penicillium variabile, considerados melhores produtores de $\beta$-galactosidase pela triagem anterior.

A transformação de um composto orgânico para obtenção de energia é um processo comumente desenvolvido por microrganismos (bactérias, fungos e leveduras) cujo desempenho depende muito da composição do meio de cultura onde são colocados (88), pois cada ser vivo responde de maneira única ao ambiente, usando mecanismos físicos ou químicos para a formação do produto desejado (112).

Visando um aumento na síntese enzimática, a otimização do processo de produção da enzima foi realizada variando-se a oferta de carbono e nitrogênio através da adição de nutrientes como a glicose, peptona e extrato de levedura aos meios contendo tanto casca de soja como okara. Sabe-se que, em geral, um aumento no balanceamento C:N favorece a produção de metabólitos (111). A Figura 7 mostra o perfil de produção enzimática para os três fungos nos meios de cultivo com suplementação de carbono e nitrogênio. 


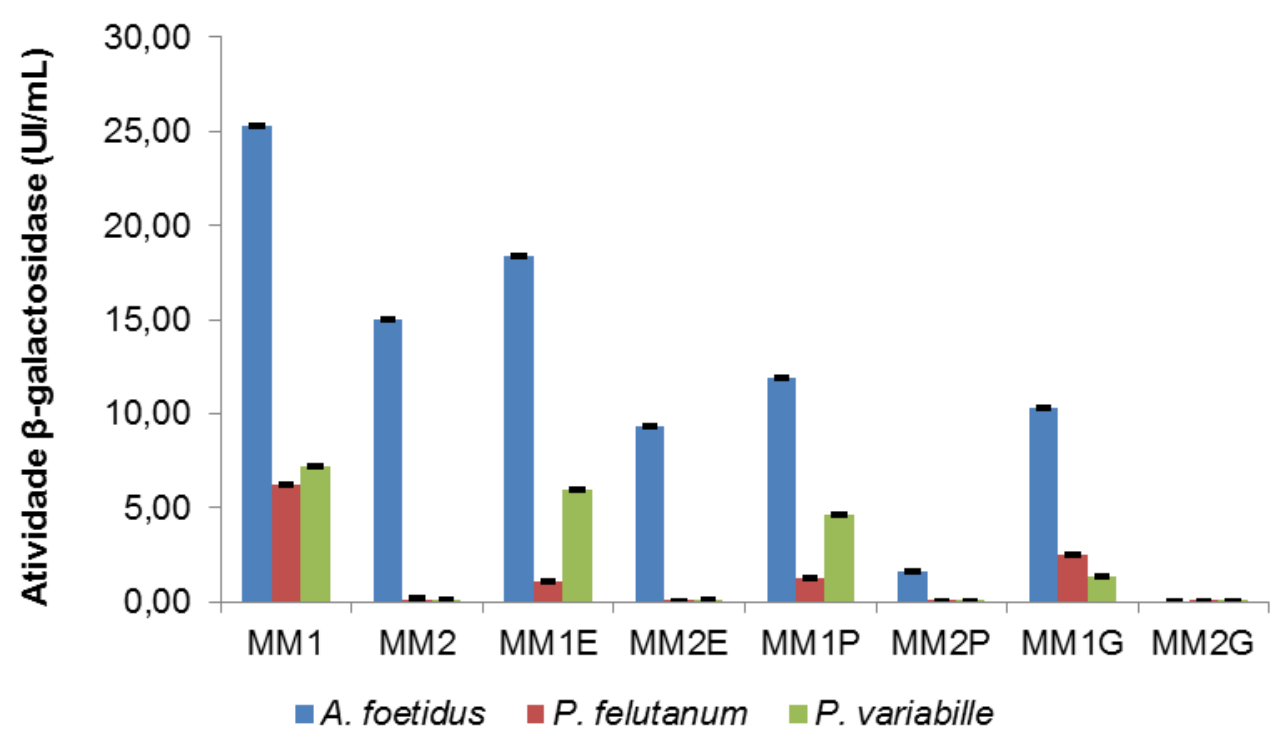

Figura 7 - Atividade $\beta$-galactolítica em A. foetidus, $P$. felutanum e $P$. variabile, cultivados a $120 \mathrm{rpm}$, $28^{\circ} \mathrm{C}$ por 7 dias. MM1 - meio mínimo com casca de soja 2\%; MM2 - meio mínimo com $2 \%$ okara. MME1 meio mínimo com casca de soja $2 \%+0,4 \%$ extrato de levedura; MME2- meio mínimo com $2 \%$ okara $+0,4 \%$ extrato de levedura; MMP1 - meio mínimo com 2\% casca de soja +0,4\% peptona; MMP2 - meio mínimo com 2\% okara + 0,4\% peptona; MMG1 - meio mínimo com $2 \%$ de casca de soja +2,0\% glicose; MMG2- meio mínimo com $2 \%$ okara $+2 \%$ glicose.

A casca de soja permaneceu sendo o melhor indutor para atividade de $\beta$ galactosidase para todos os fungos testados. Os cultivos contendo okara $2 \%$ foram menos favoráveis para produção de $\beta$-galactosidase de $A$. foetidus em comparação com MM1. Para os outros dois fungos observa-se que okara foi pouco ou quase nada, estimulador da produção enzimática, quando comparado com cultivo de $A$. foetidus em MM1. O resultado se repetiu com a suplementação dos meios com peptona e extrato de levedura.

Os dados mostrados na Figura 7 reforçam a influência da constituição do substrato sobre a atividade da enzima secretada. Os nutrientes para serem absorvidos pelos fungos devem possuir um tamanho adequado de forma que possam atravessar a parede celular fúngica (68). Logo, os componentes dos resíduos (polipeptídeos, proteínas, trissacarídeos, etc) devem, inicialmente, ser despolimerizados e hidrolizados extracelularmente em compostos menores (oligômeros e monômeros) para serem suscetíveis ao transporte, através da parede celular do microrganismo e serem absorvidos. A degradação pode ocorrer pela ação de complexos enzimáticos (enzimas oxidativas e hidrolíticas) de acordo com 
características do fungo $(91,117)$. Esses oligômeros e oligossacarídeos de cadeia curta, por ação de $\beta$-glicosidases são hidrolisados em monossacarídeos. Neste contexto, uma vez esgotado açucares do meio de cultivo, a $\beta$-galactosidase (consideradas glicosidases) (35) pode ter sido expressa pelo fungo para participar desse processo de hidrólise de dissacarídeos na obtenção de D-glicose, Dgalactose.

No entanto, a ausência de expressão de enzimas específicas pode fazer fracassar a degradação de em um determinado substrato, por ser incapaz de digerilo (68). Sugere-se que esta seja uma das hipóteses pelo qual os fungos $P$. felutanum e $P$. variabile não tenham apresentado atividade enzimática no meio MM2.

Infere-se também que a casca de soja detenha maior teor de material lignocelulósico extratível (19). É possível que na segunda fonte (MM2), o acesso ao carbono e nitrogênio necessários para o crescimento do fungo esteja menos disponível, uma vez que possuem menor fração hemicelulósica (fração que é hidrolisada em monossacarídeos), resultando em uma menor liberação enzimática. Por outro lado, nos substratos com partículas de tamanho menores como, peptona, extrato de levedura e outros hidrolisados de proteínas há a possibilidade da absorção pelo fungo ser facilitada, sem a necessidade de dispor da síntese de enzimas no meio extracelular (111). Esse fato, pode explicar a menor atividade de $\beta$ galactosidase no meio MM1E e MM1P. Ainda em relação à suplementação de peptona e extrato de levedura, sabe-se que um aumento na quantidade de nitrogênio no meio de cultivo favorece a síntese de ácido nucleico pelo fungo e o consequente crescimento da biomassa. A $\beta$-galactosidase parece não estar associada à fase de crescimento do fungo. Foi observado que a adição de nitrogênio não favoreceu a rota metabólica para a produção desta enzima provavelmente proporcionando a divisão celular.

O cultivo de Aspergillus foetidus em okara (MM2) resultou em uma atividade de $\beta$-galactosidase em torno de $40 \%$ menor em relação ao meio com casca de soja (MM2). A diminuição na produção enzimática para esse cultivo, além dos fatores já citados, pode também, estar associada à presença de ácido fítico. Segundo O'Toole (1999) e colaboradores, okara possui de 0,5 a $1 \%$ de ácido fítico em sua composição (96). Sugere-se que a capacidade quelante do ácido fítico presente no 
okara inviabiliza o uso dos micronutrientes presentes no meio de cultivo, pois o ácido fítico é um agente quelante. Esse agente tem a capacidade de sequestrar minerais, como zinco, cálcio, ferro, entre outros, aderindo esses metais a sua estrutura, e com isso tornando-os insolúveis e dificultando a absorção pelo fungo (118).

Constatou-se também que o pH final do meio utilizando a casca de soja como substrato foi mais ácido ( $\mathrm{pH}$ 2,65) em comparação com okara ( $\mathrm{pH} 4,50)$. Assim, o pH do meio pode ter modulado a atividade enzimática no meio extracelular. Outra forma de modulação pode estar na expressão de diferentes proteínas produzidas pelo mesmo fungo de acordo com a composição do meio. Sabe-se que proteínas podem inibir ou degradar a $\beta$-galactosidase presente no meio. A Figura 8 ilustra a diferença no perfil proteico do $A$. foetidus cultivado em okara e casca de soja, e a diversidade de proteínas num mesmo cultivo. O aumento na concentração de proteases no meio enriquecido com peptona pode ter degradado a $\beta$-galactosidase do meio (MM1P e MM2P), pois segundo a literatura peptonas estimulam a produção de proteases de Aspergillus foetidus (119).

(1)

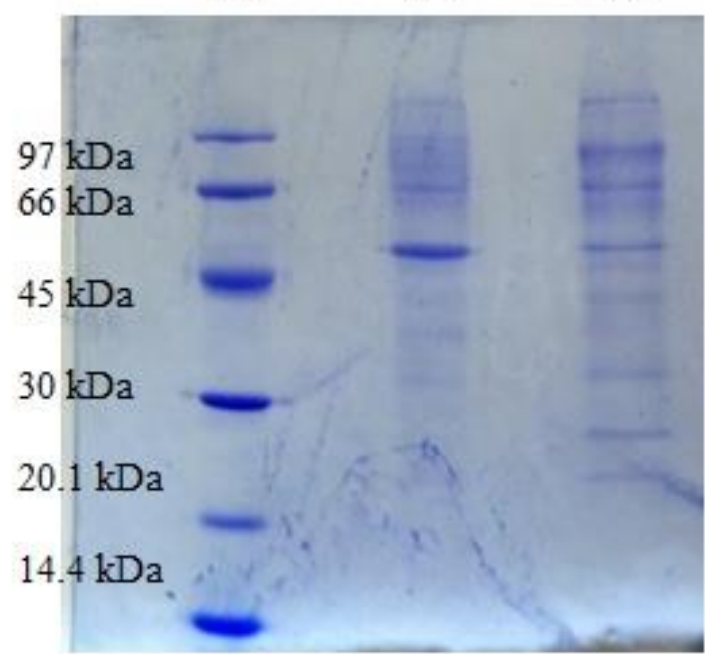

Figura 8 - Eletroforese em gel desnaturante de poliacrilamida do cultivo de A.foetidus em resíduo da soja. (1) Padrão de massa molar: fosforilase b (97 kDa), albumina (66 kDa), ovoalbumina (45 kDa), anidrase carbônica (30 kDa), inibidor de tripsina (20.1 kDa) e a-lactalbumina (14.4 kDa); (2) perfil protéico do A. foetidus cultivado em okara; (3) perfil protéico do $A$. foetidus cultivado em casca de soja.

Em relação ao meio MMG1 e MMG2 observou-se que um provável fenômeno de repressão catabólica foi provocado pela concentração de glicose no meio. Nagy 
et al. (2001), observaram que a $\beta$-galactosidase do Penicillium chrysogenum foi reprimida pela glicose e induzida pela lactose (42), o mesmo foi descrito por Braga et al. (2012), em relação ao gênero Kluyveromyces.(115). Sen Sucharita et.al, (2012) também observaram o efeito inibitório da glicose na atividade da $\beta$-galactosidase de Aspergillus alliaceus (44).

Uma vez selecionado o fungo $A$. foetidus e o meio contendo casca de soja como a combinação para melhor produção enzimática, a lactose foi utilizada na tentativa de ser um indutor para produção de $\beta$-galatosidase de $A$. foetidus. Estudos relatam o efeito positivo da lactose sobre a expressão de $\beta$-galactosidases de origem fúngica em meio líquido de cultivo $(42,120)$. Assim, foram realizados ensaios adicionando lactose $2 \%$ no meio de cultivo com casca de soja (Figura 9).

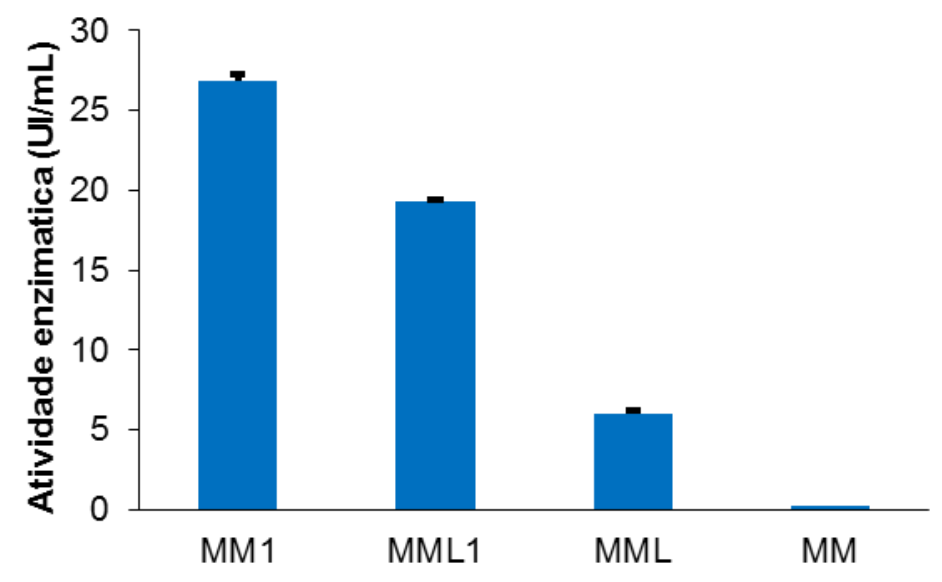

Figura 9 - Avaliação da produção enzimática de A. foetidus sob a influência da lactose. MM1 - meio mínimo contendo casca de soja $2 \%$; MML1 - meio mínimo contendo casca de soja $2 \%$ e lactose $2 \%$; MML meio mínimo com $2 \%$ lactose sem casca de soja; MM - meio mínimo sem casca de soja e sem lactose.

No entanto, neste trabalho, a lactose não induziu a produção de $\beta$ galactosidase, isso pode ser explicado pela complexidade da fonte de carbono, como discutido acima, onde o fungo teria preferencialmente utilizado a lactose como fonte de carbono para seu crescimento. Talvez aumentando o tempo de cultivo, poderia ocorrer o esgotamento da lactose com início da degradação da casca de 
soja por enzimas lignocelulóliticas. Desta forma, os oligômeros e dissacarídeos resultantes teriam induzido o fungo a excretar $\beta$-galactosidases (114).

Esse resultado corrobora com o resultado anterior, comprovando a influência positiva da casca de soja na produção de $\beta$-galactosidases.

\subsection{CURVA DE INDUÇÃO ENZIMÁTICA}

Após a escolha da composição de meio de cultivo, a etapa posterior baseouse no conhecimento do padrão de liberação de enzima no meio de cultivo pelo Aspergillus foetidus. Para isso foi realizado um perfil de indução enzimático de 20 dias, avaliando diariamente a produção de $\beta$-galactosidase e de proteínas totais. A curva de indução enzimática do Aspergillus foetidus crescido em meio com casca de soja (Figura 10) elucidou o tempo de cultivo necessário para se obter o pico de produção máxima de $\beta$-galactosidases excretadas extracelularmente pelo fungo.

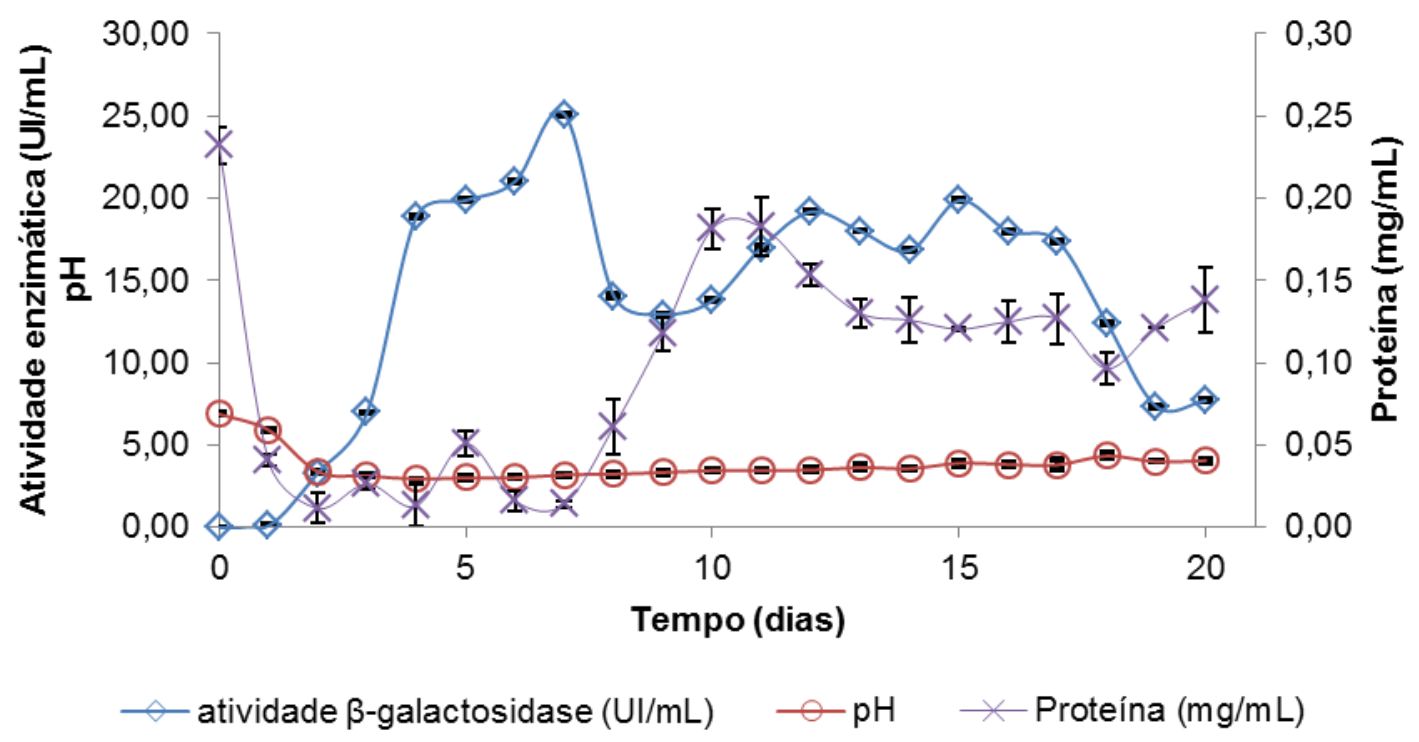

Figura 10 - Curva de indução enzimática para o $A$. foetidus cultivado em casca de soja $2 \%+$ meio mínimo (MM1) durante 20 dias. Cultivo realizado em shaker, $120 \mathrm{rpm}, 28^{\circ} \mathrm{C}$. 
O aumento da expressão enzimática foi progressivo indicando atividade a partir do $3^{\circ}$ dia de cultivo, tendo sua produção e atividade específica máxima no $7^{\circ}$ dia de cultivo, cujos valores são 25,11 Ul/mL e 1793,64 Ul/mg, respectivamente.

Percebe-se que a quantidade de proteína oscilou durante o cultivo, sugerindo que este resultado abrange outras enzimas além da $\beta$-galactosidase que são produzidas concomitantemente e que também participam do processo de degradação do substrato.

A queda da atividade próximo ao vigésimo dia de cultivo, pode estar relacionada com o esgotamento dos nutrientes presentes no meio, como a glicose, uma vez que não ocorreu adição de nutrientes ao meio durante o período estudado.

O perfil de indução foi acompanhado por uma variação de $\mathrm{pH}$, tendo valor máximo de $\mathrm{pH}$ igual a 5,92 no primeiro dia de cultivo e valor mínimo de 2,94 no $4^{\circ}$ dia. Segundo Colen (2006) e Galvagno et al. (2010), o metabolismo do fungo, durante o crescimento, altera o pH do meio de cultivo, seja pela absorção de ânions ou cátions ou pela produção de ácidos orgânicos ou amônia $(68,111)$. A concentração de íons hidrogênio no meio pode afetar o crescimento indiretamente pelo seu efeito na disponibilidade de nutrientes ou diretamente pela a sua ação nas superfícies celulares (111).

Uma segunda curva de indução de 10 dias foi realizada variando o $\mathrm{pH}$ do meio, com a tentativa de aumentar a produtividade da enzima de interesse através da diminuição do tempo de cultivo, uma vez que, observou-se a que a queda no $\mathrm{pH}$ do meio coincidiu com o início da atividade enzimática demonstrado na Figura 11. 


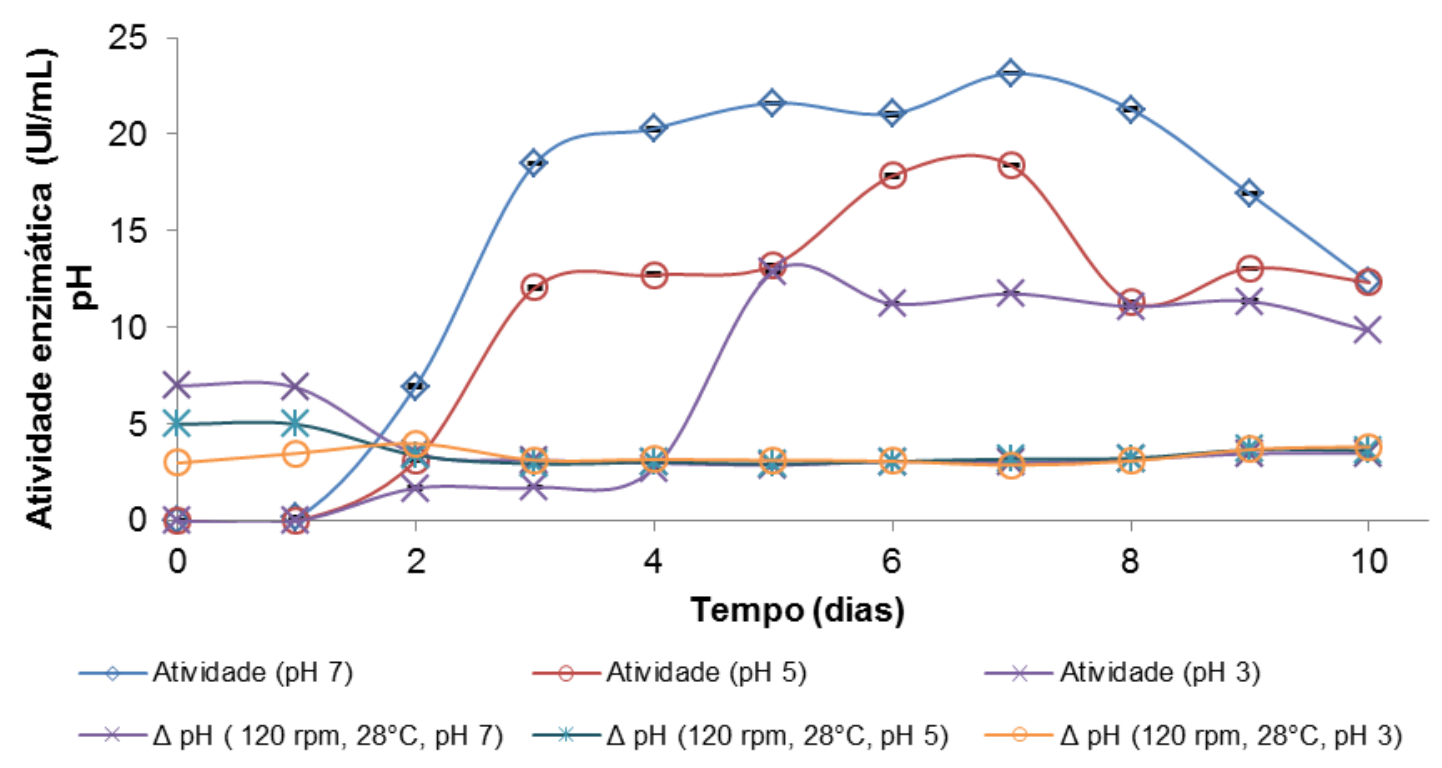

Figura 11 - Curva de indução enzimática do $A$. foetidus cultivado em casca de soja $2 \%$ + meio mínimo (MM1) de 10 dias em pH 3, 5 e 7.

A atividade de $\beta$-galactosidase e $\mathrm{pH}$ foram monitorados ao longo do tempo nas condições de cultivo de $120 \mathrm{rpm}, 28^{\circ} \mathrm{C}$ e pH $3 ; 5$ e 7.

$\mathrm{Na}$ curva de indução enzimática em $\mathrm{pH} 3$, o pico de atividade ocorreu no quinto dia $(12,9 \mathrm{Ul} / \mathrm{mL})$ enquanto que em $\mathrm{pH} 7$ e 5 , o pico ocorreu no sétimo dia $(23,1 \mathrm{Ul} / \mathrm{mL})$ e $(18,4 \mathrm{UI} / \mathrm{mL})$, respectivamente. A curva em $\mathrm{pH} 7$ manteve a atividade elevada durante todo o período analisado, sendo que a partir do $3^{\circ}$ dia já apresentou valores maiores do que em $\mathrm{pH} 3$ e 5 . A atividade enzimática atingiu um valor máximo $(23,1 \mathrm{Ul} / \mathrm{mL})$, após $168 \mathrm{~h}$ (7 dias) do cultivo a $120 \mathrm{rpm}, 28^{\circ} \mathrm{C}, \mathrm{pH} 7 . \mathrm{Em}$ seguida, diminuiu, para 12,3 Ul/ml.

Tem-se observado que fungos filamentosos sintetizam compostos complexos que são supostamente úteis, mas não necessários para a sua sobrevivência. Observando a Figura 11 e avaliando o perfil de atividade enzimática apresentado pelo microrganismo, sugere-se que a $\beta$-galactosidase expressa em meio líquido possa ser um metabólito secundário produzido em maior quantidade na fase estacionária de crescimento. Porém, o perfil de crescimento do fungo (quantificação da biomassa) deve ser realizado para confirmar esta hipótese. Até o momento, a biomassa não foi quantificada, pois a metodologia de quantificação de ergosterol em matriz fúngica está sendo validado pelo grupo de pesquisa. 


\subsection{DELINEMENTO EXPERIMENTAL}

Os efeitos das variáveis independentes temperatura de incubação, $\mathrm{pH}$ inicial do meio e agitação na produção de $\beta$-galactosidases pelo Aspergillus foetidus em casca de soja $2 \%$, foram avaliados usando um delineamento experimental com adição de três ensaios no ponto central. Segundo a literatura, modelos de planejamento que realizam três replicatas no ponto central são mais confiáveis. O risco de perder a relação não linear entre os intervalos é minimizado e é possível estimar um modelo razoável e verificar se há falta de ajuste. Outra vantagem da inclusão de experimentos no centro do planejamento é devida a estimativa do erro com poucas repetições, normalmente entre 3 e 5 (121).

O tempo de cultivo e os valores de $\mathrm{pH}$ e agitação do ponto central, foram escolhidos para realização do planejamento com base na curva de crescimento, realizada em diferentes $\mathrm{pH}$ (Figura 11).

O desenho fatorial em 02 níveis assume linearidade nos efeitos dos fatores. Neste estudo, os fatores de limites inferiores e limites superiores foram codificados com -1 e +1 respectivamente e o ponto central foi codificado como 0 . Os níveis das variáveis estão apresentados conforme a Tabela 4, previamente descrita no item 4.7. A produção de $\beta$-galactosidase foi a variável dependente para determinar a efetividade do desenho experimental, onde os resultados obtidos encontram-se resumidos na Tabela 6 . 
Tabela 6 - Resultado do planejamento fatorial $2^{3}$ para análise da influência das variáveis (agitação, temperatura e $\mathrm{pH}$ ) frente a produção de $\beta$ - galactosidase

\begin{tabular}{lllllllc}
\hline & \multicolumn{3}{l}{ Variáveis codificadas } & \multicolumn{2}{l}{ Variáveis reais } & Atividade enzimática \\
\cline { 2 - 7 } Ensaio & $\mathrm{X} 1$ & $\mathrm{X} 2$ & $\mathrm{X} 3$ & $\begin{array}{l}\mathrm{A} \\
(\mathrm{rpm})\end{array}$ & $\mathrm{T}\left({ }^{\circ} \mathrm{C}\right)$ & $\mathrm{pH}$ & $\mathrm{Ul} / \mathrm{mL}$ \\
\hline 1 & -1 & -1 & -1 & 100 & 22 & 5 & 19,640 \\
2 & +1 & -1 & -1 & 140 & 22 & 5 & 19,026 \\
3 & -1 & +1 & -1 & 100 & 34 & 5 & 7,074 \\
4 & +1 & +1 & -1 & 140 & 34 & 5 & 8,830 \\
5 & -1 & -1 & +1 & 100 & 22 & 9 & 10,060 \\
6 & +1 & -1 & +1 & 140 & 22 & 9 & 0,035 \\
7 & -1 & +1 & +1 & 100 & 34 & 9 & 0,000 \\
8 & +1 & +1 & +1 & 140 & 34 & 9 & 1,120 \\
9 & 0 & 0 & 0 & 120 & 28 & 7 & 23,400 \\
10 & 0 & 0 & 0 & 120 & 28 & 7 & 24,640 \\
11 & 0 & 0 & 0 & 120 & 28 & 7 & 22,600 \\
\hline
\end{tabular}

A atividade da $\beta$-galactosidase variou de zero a $24,64 \mathrm{UI} / \mathrm{mL}$. Essa ampla variação reflete a importância da otimização das condições de cultivo na produtividade enzimática. A atividade enzimática máxima foi obtida quando Aspergillus foetidus foi cultivado sob condições de agitação de $120 \mathrm{rpm}$, temperatura de $28^{\circ} \mathrm{C}$ e pH inicial do meio igual a 7,0 . Enquanto que em $\mathrm{pH} 9,0$ com uma temperatura de $34^{\circ} \mathrm{C}$ houve queda acentuada da produção enzimática. Este fato pode ter ocorrido, porque em $\mathrm{pH}$ extremos uma pequena mudança na temperatura aumenta a desnaturação térmica da enzima. Além disso, a concentração de íon hidrogênio no meio pode afetar o crescimento do fungo indiretamente pelo seu efeito na disponibilidade de nutrientes ou diretamente pela sua ação nas superfícies celulares, como já explicado anteriormente.

Apesar da importância da temperatura na produção de enzimas microbianas (122), os dados sobre o efeito desta variável na atividade enzimática são raros na literatura (123). De acordo com Rahman et.al (2005), a temperatura pode causar mudanças nas propriedades físicas da membrana celular, e com isso afetar também 
a síntese de enzimas extracelulares (122). No estudo de Sudharhsan et al. (2007), dados demonstram a influência do $\mathrm{pH}$ e da temperatura sobre a diminuição na síntese e secreção de amilases microbianas em cultivos sob temperaturas elevadas (124).

A rotação não apresentou influência na produção de $\beta$-galactosidase no intervalo estudado, enquanto que $0 \mathrm{pH}$ e a temperatura interferiram significativamente na atividade enzimática.

Os fatores analisados para produção de $\beta$-galactosidase são demonstrados na Tabela 7 através da análise de variância (ANOVA). A temperatura (X2) e $\circ \mathrm{pH}$ $(X 3)$, exerceram efeitos significativos sobre a produção enzimática $(p \leq 0,05)$. A análise de variância revelou que o coeficiente de determinação $\left(R^{2}=0,973\right)$ e 0 coeficiente de determinação ajustado $\left(R^{2}=0,9199\right)$ foram altos. Valores acima de $75 \%$ indicam que os fatores no experimento representam a grande porcentagem de variação observada. Neste estudo, o $R^{2}$ ajustado foi igual a $91,99 \%$. Se o modelo representa de forma adequada o fenômeno, a falta de teste não deve ser significativa $(p>0,05)(125)$. O valor obtido de $p$ para a falta de ajuste foi 0,094 , 0 que não indica significância e, portanto, indica que o modelo é apropriado para este estudo. 
Tabela 7 - Analise de variância (ANOVA) para o modelo de segunda ordem para otimização da produção de $\beta$-galactosidase. Incluindo as variáveis independentes: Agitação (X1), Temperatura (X2) e $\mathrm{pH}(\mathrm{X} 3)$

\begin{tabular}{llllll}
\hline Fonte & $\mathrm{SQ}$ & $\mathrm{GL}$ & $\mathrm{MQ}$ & F-value & p-value \\
\hline Modelo & 427,60 & 6 & 71,26 & 18,229 & 0,0185 \\
Rotação (X1) & 7,533 & 1 & 7,53 & 1,924 & 0,2594 \\
Temperatura(X2) & 125,90 & 1 & 125,90 & 32,19 & 0,0109 \\
$\mathrm{pH}(\mathrm{X} 3)$ & 234,95 & 1 & 234,95 & 60,10 & 0,0045 \\
$\mathrm{X} 1: \mathrm{X} 2$ & 22,83 & 1 & 22,83 & 5,84 & 0,0944 \\
X1:X3 & 12,61 & 1 & 315,67 & 3,22 & 0,1704 \\
X2:X3 & 23,76 & 1 & 6,073 & 0,0905 & 0,0905 \\
Falta de ajuste & 9,62 & 1 & 240,38 & 9,1100 & 0.0945 \\
Erro puro & 2,11 & 2 & 26,41 & & \\
\hline
\end{tabular}

Modelo de regressão: Atividade $\beta$-galactosidase $=8,223-0,970^{*} X 1-3,967^{*} X 2-5,419^{*} X 3+$ $1,689^{*} X 1^{\star} X 2-1,255^{*} X 1^{*} X 3+1,723^{*} X 2^{*} X 3$

$S Q=$ soma dos quadrados; $G L=$ grau de liberdade; $M Q=$ meia do quadrado; $R^{2}=0,9733 .{ }^{*}$ Nível de significância de $95 \%$.

De acordo com a Tabela 7, o modelo abaixo foi proposto:

Atividade $\beta$-galactosidase $=8,223-0,970^{*} X 1-3,967^{*} X 2-5,419^{*} X 3+$ $1,689^{*} X 1^{*} X 2-1,255^{*} X 1^{*} X 3+1,723^{*} X 2^{*} X 3$

Onde, $\mathrm{X} 1$ é agitação (rpm), $\mathrm{X} 2$ é a temperatura $\left({ }^{\circ} \mathrm{C}\right)$ e $\mathrm{X} 3$ é o $\mathrm{pH}$. A equação em termos do modelo pode ser usada para estimar a resposta da atividade de $\beta$ galactosidase considerando o intervalo das variáveis testadas no experimento.

A ANOVA revelou os efeitos principais e a existência de interação entre eles. O gráfico de Pareto (Figura 12) e o gráfico de superfície resposta representado na Figura 13 mostra o efeito das interações. No gráfico de Pareto, o comprimento de cada barra é proporcional ao efeito padronizado da variável ou relacionado com a interação, enquanto que as barras que se estendem acima da linha horizontal correspondem aos efeitos estatisticamente significativos a um nível de confiança de $95 \%$. De acordo com a análise, observa-se que o maior efeito significativo foi a temperatura e o $\mathrm{pH}$ provocando diminuição na atividade enzimática. Logo, efeitos 
das variáveis X2 e X3 apresentam uma estimativa de sinal negativo, implicando que aumentos na temperatura e $\mathrm{pH}$ tendem a menores valores de atividade enzimática. A agitação não foi significativa no modelo testado. No entanto, a possibilidade de influência da agitação em outras condições não testadas não pode ser excluída.

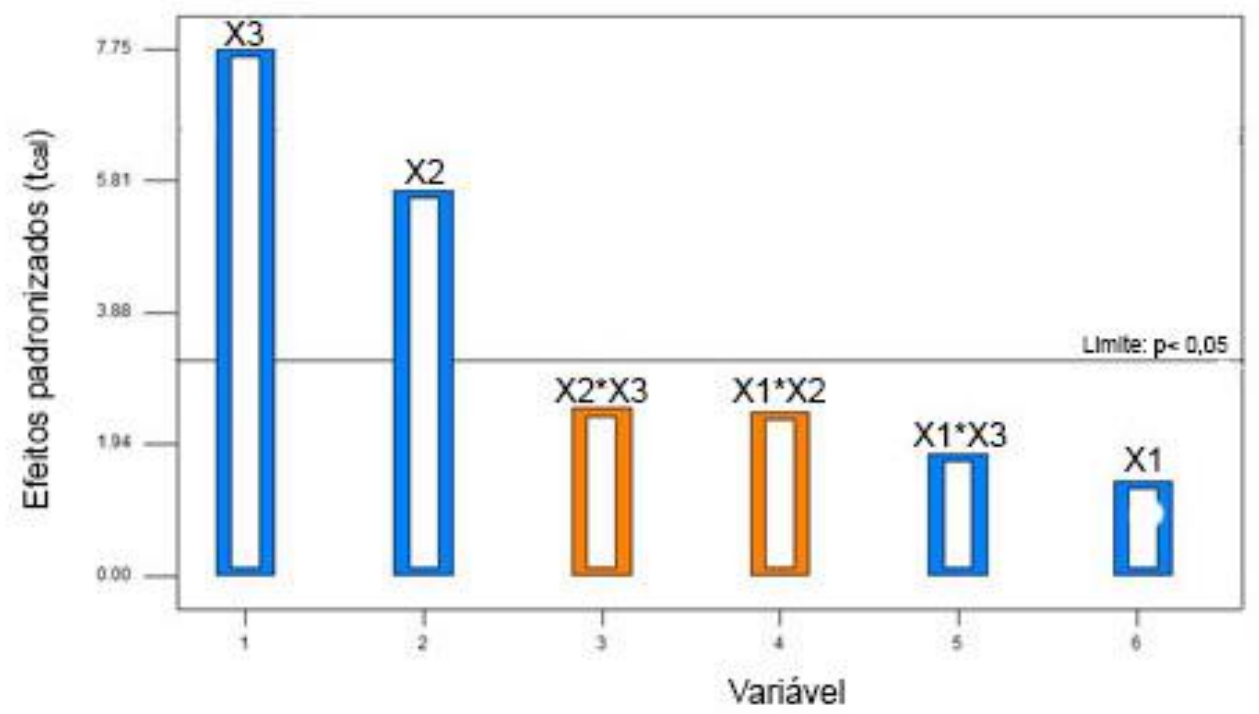

Figura 12 - Gráfico de pareto para os efeitos das variáveis agitação (X1), temperatura (X2) e pH (X3) na atividade de $\beta$-galactosidase.
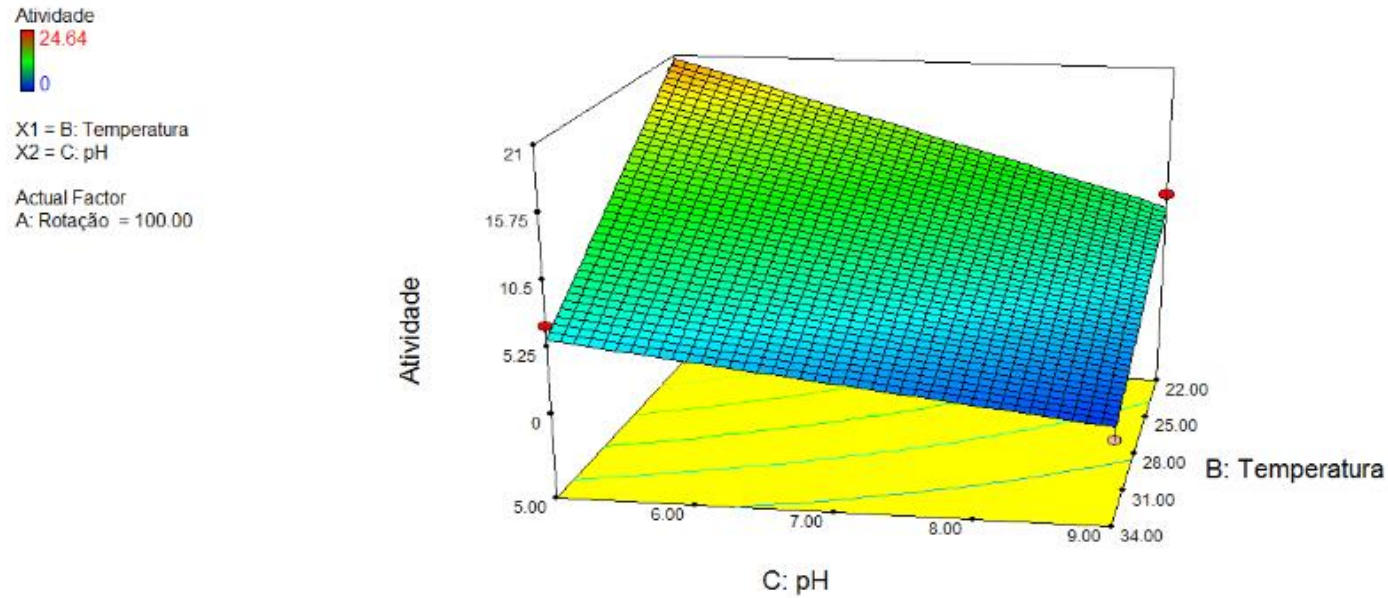

Figura 13 - Gráfico de superfície resposta para atividade de $\beta$-galactosidase em função das variáveis X2 (temperatura) e X3 $(\mathrm{pH})$. 
O modelo experimental adotado descreve que o melhor resultado para a produção da $\beta$-galactosidase é encontrado no centro do planejamento com uma temperatura de $28^{\circ} \mathrm{C}$ associado a um pH neutro. Assim, para aplicações futuras, os experimentos devem ser testados em condições próximas ao indicado neste trabalho.

\subsection{PURIFICAÇÃO}

Após o período de cultivo do Aspergillus foetidus em casca de soja nas condições mais apropriadas estabelecidas pelos ensaios anteriores, o caldo fermentado foi filtrado utilizando sistema de filtração a vácuo e centrifugado dando início ao processo de purificação enzimática.

O sobrenadante denominado extrato bruto $(E B)$ obtido, foi submetido à ultrafiltração em membrana de $100 \mathrm{kDa}$ e $30 \mathrm{kDa}$ visando a separação por massa molecular das proteínas presentes no caldo fermentado. Concentrar proteínas por ultrafiltração tem várias vantagens, como promover a concentração de compostos a baixa temperatura e pressão, possibilitar a retirada de sais e outras moléculas pequenas mantendo constante o $\mathrm{pH}$ do meio (66). Primeiramente, o extrato bruto foi concentrado pela membrana de $100 \mathrm{kDa}$, obtendo-se uma fração concentrada $(>100)$ e ultrafiltrada $(<100)$. A fração ultrafiltrada, embora contendo a maior atividade enzimática para $\beta$-galactosidase, não apresentou aumento no fator de purificação, sendo então submetida ao meio filtrante com poros de $30 \mathrm{kDa}$. A maior parte da $\beta$-galactosidase foi identificada na fração concentrada $(>30)$ apresentando atividade específica superior ao extrato bruto e um fator de purificação igual a 2,0, portanto a etapa de purificação posterior foi realizada com esta fração (Tabela 8). 
Tabela 8 - Descrição da atividade enzimática de $\beta$-galactosidase e proteína obtida nas etapas de ultrafiltração por membranas de $100 \mathrm{kDa}$ e $30 \mathrm{kDa}$

\begin{tabular}{cccccc}
\hline Frações & $\begin{array}{c}\text { Proteína } \\
(\mathrm{mg} / \mathrm{mL})\end{array}$ & $\begin{array}{c}\text { Atividade } \\
(\mathrm{Ul} / \mathrm{mL})\end{array}$ & $\begin{array}{c}\text { Atividade } \\
\text { específica }(\mathrm{Ul} / \mathrm{mg})\end{array}$ & $\begin{array}{c}\text { Rendimento } \\
(\%)\end{array}$ & $\begin{array}{c}\text { Fator de } \\
\text { purificação }\end{array}$ \\
Bruto & 0,150 & 26,000 & 173,333 & 100,000 & 1,000 \\
$<100$ & 0,144 & 24,000 & 166,667 & 92,308 & 0,962 \\
$>30$ & 0,065 & 23,440 & 360,615 & 90,154 & 2,080 \\
\hline
\end{tabular}

\subsubsection{Cromatografia}

O perfil cromatográfico da fração concentrada $(>30)$ em resina de exclusão molecular ou gel filtração, Sephacryl S-200, revelou a presença de dois picos proteicos. No primeiro pico, denominado pico 1 S-200, detectou-se a atividade $\beta$ galactolítica conforme apresentado na Figura 14.

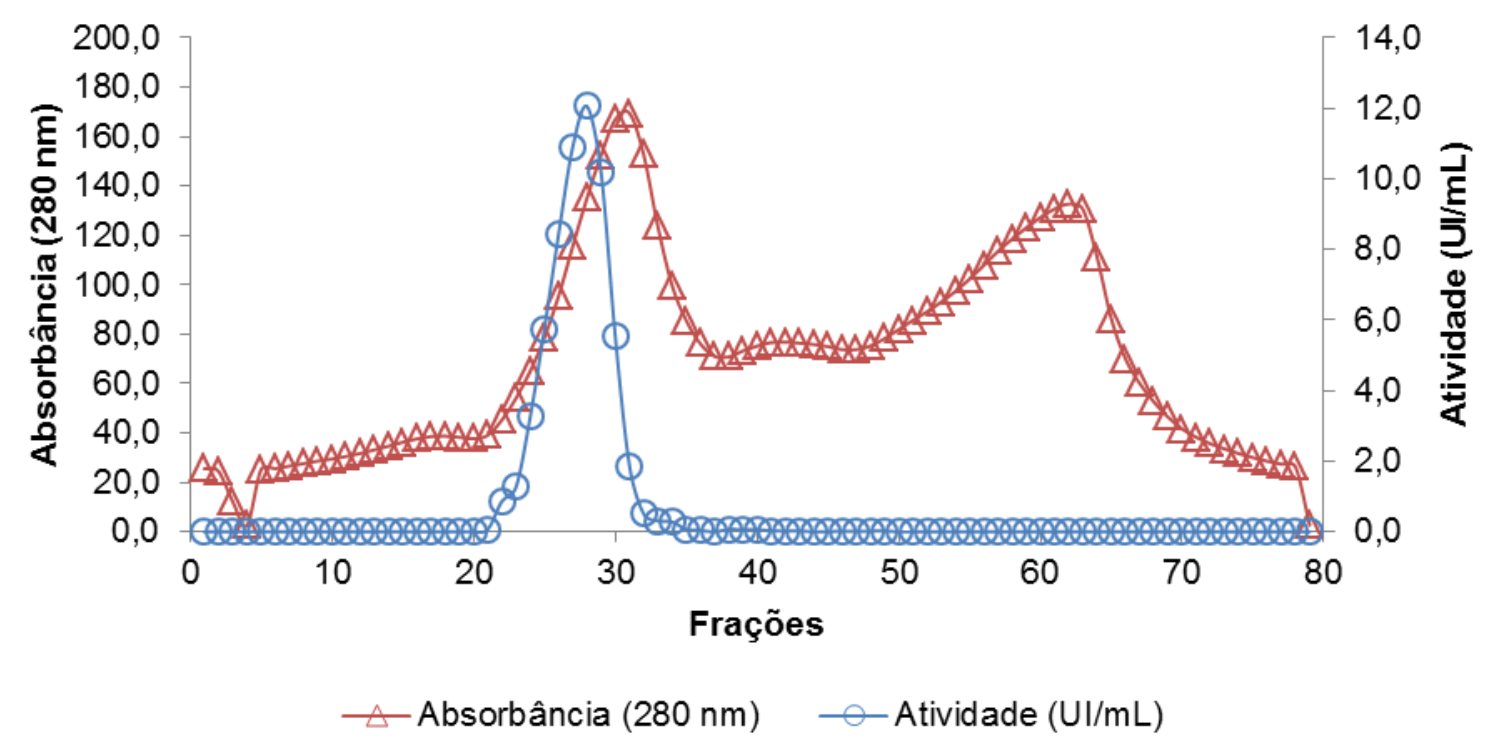

Figura 14 - Perfil cromatográfico da fração concentrada $>30$ em coluna de gel filtração Sephacryl S200 com tampão fosfato de sódio $0,1 \mathrm{M} \mathrm{pH} 7$ e fluxo de $0,5 \mathrm{~mL} / \mathrm{min}$. 
$\mathrm{Na}$ cromatografia de filtração em gel, as amostras eluídas da fração 23 a 31 quando reunidas apresentaram atividade enzimática de 6,57 UI/mL, que corresponde a um volume de retenção de $62 \mathrm{~mL}$. As frações selecionadas reunidas (pico $1 \mathrm{~S}-200$ ) foram armazenas a $4^{\circ} \mathrm{C}$ para posterior cromatografia de troca iônica. No último pico nas frações de número 60 a 61 foi eluída grande parte da cor presente da amostra.

O pico 1 S-200 foi eluído em resina de troca iônica do tipo aniônica DEAE- FF representado no cromatograma da Figura 15.

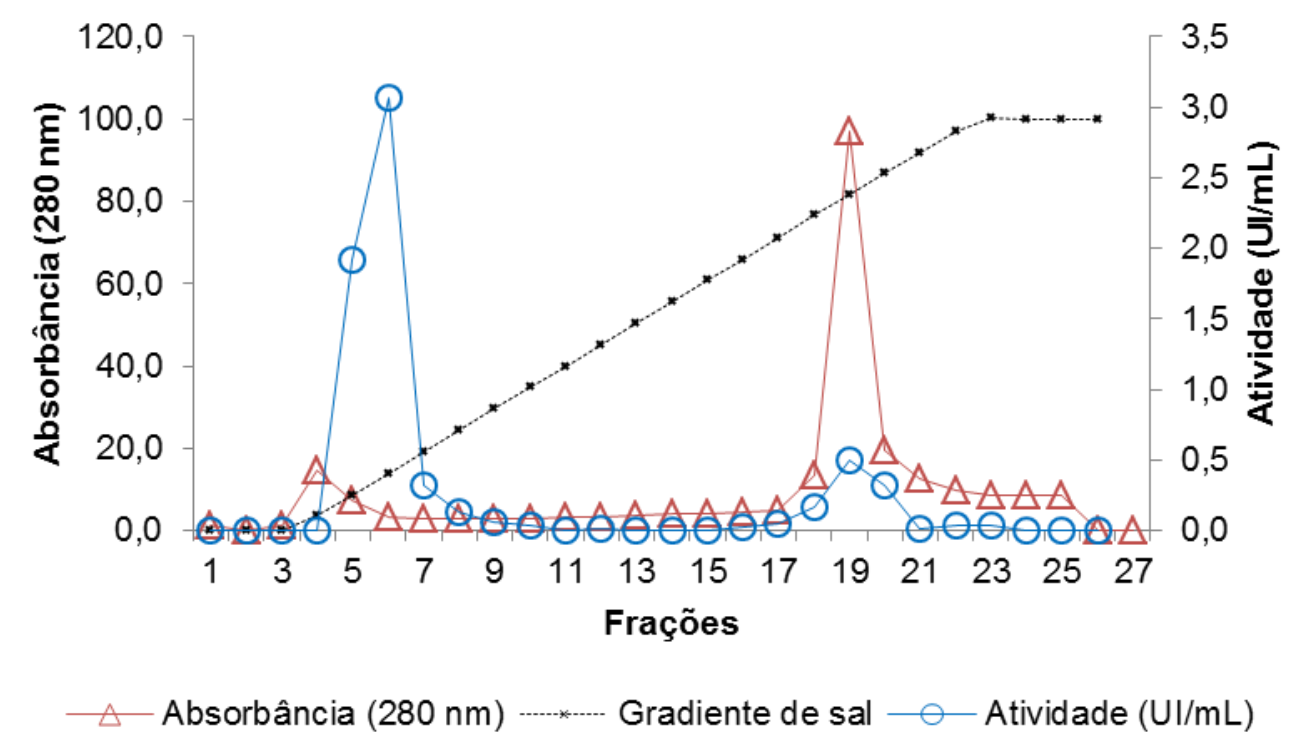

Figura 15 - Perfil cromatográfico da fração concentrada do pico 1 S-200 eluída em coluna de troca iônica do tipo HiTrap DEAE-FF em pH 7,0 com fluxo fixo de 0,250 ml/min e gradiente de $\mathrm{NaCl}(0-$ $1,0 \mathrm{M})$.

Pelo perfil cromatográfico, pode-se visualizar que a amostra possui dois picos proteicos com diferentes forças de interação com a resina, as quais são determinadas pela quantidade e localização das cargas na molécula. A $\beta$ galactosidase, Pico 1 S-200, foi eluída majoritariamente na fração 5 e 6 (pico 1 DEAE) com fraca ligação à resina, pois uma baixa concentração de $\mathrm{NaCl}$ foi necessária para neutralizar a sua interação com a resina. No segundo pico eluído 
(pico 2 DEAE) foi observada uma baixa atividade enzimática $(0,33 \mathrm{UI} / \mathrm{mL})$ e maior quantidade de proteína, quando comparado com o Pico 1 DEAE (3,06 Ul/mL).

Na Tabela 8 está apresentado o resumo das etapas de purificação realizadas neste trabalho. Observa-se um aumento de aproximadamente 8 vezes na atividade específica da $\beta$-galactosidase em relação ao EB e consequentemente um aumento superior a 8 vezes em seu fator de purificação.

Tabela 9 - Resumo das etapas de purificação de $\beta$-galactosidase produzida por $A$. foetidus cultivado em casca de soja como fonte de carbono

\begin{tabular}{cccccc}
\hline Frações & $\begin{array}{c}\text { Proteína } \\
(\mathrm{mg} / \mathrm{mL})\end{array}$ & $\begin{array}{c}\text { Atividade } \\
(\mathrm{Ul} / \mathrm{mL})\end{array}$ & $\begin{array}{c}\text { Atividade } \\
\text { específica }(\mathrm{Ul} / \mathrm{mg})\end{array}$ & $\begin{array}{c}\text { Rendimento } \\
(\%)\end{array}$ & $\begin{array}{c}\text { Fator de } \\
\text { purificação }\end{array}$ \\
Bruto & 0,150 & 26,000 & 173,333 & 100,000 & 1,000 \\
$<100$ & 0,144 & 24,000 & 166,667 & 92,308 & 0,962 \\
$>30$ & 0,065 & 23,440 & 360,615 & 90,154 & 2,080 \\
S-200 & 0,0075 & 6,570 & 876,000 & 25,269 & 5,054 \\
DEAE & 0,003 & 4,506 & 1502,000 & 17,331 & 8,665 \\
\hline
\end{tabular}

Dados na literatura apresentam algumas estratégias para purificar $\beta$ galactosidases a partir de fungos filamentosos. Algumas das metodologias envolvem várias etapas de cromatografias obtendo fator de purificação e graus de rendimentos variados. Nagy et al. (2001) purificaram $\beta$-galactosidase do fungo Penicillium chrysogenum através de coluna de troca iônica e afinidade, conseguindo índice de purificação igual a 66 e um rendimento de $8 \%$ (42). O'Connel e Walsh, (2008) purificaram duas isoformas de $\beta$-galactosidase de Aspergillus carbonarius alcançando fator de purificação 6 e 3 e rendimento de $5 \%$ e 1\% através das técnicas cromatográficas de gel filtração, troca iônica e hidrofobicidade (7). Isobe et.al, 2013 purificaram duas sub-unidades de $\beta$-galactosidase do fungo Theratosphaeria acidotherma atingindo fator de purificação e rendimento de 375 e 2,9\% respectivamente. Para isso utilizaram cromatografia de troca iônica (DEAE), gel filtração, hidrofobicidade e coluna de afinidade (120). 
O perfil proteico de cada etapa de purificação da $\beta$-galactosidase de $A$. foetidus foi acompanhado por eletroforese.

Na Figura 16, o EB, a fração ultrafiltrada $(<100)$ e a fração concentrada $(>30)$ e S-200, foram submetidas ao processo de eletroforese em gel desnaturante (SDSPAGE) para a comparação das etapas de purificação.

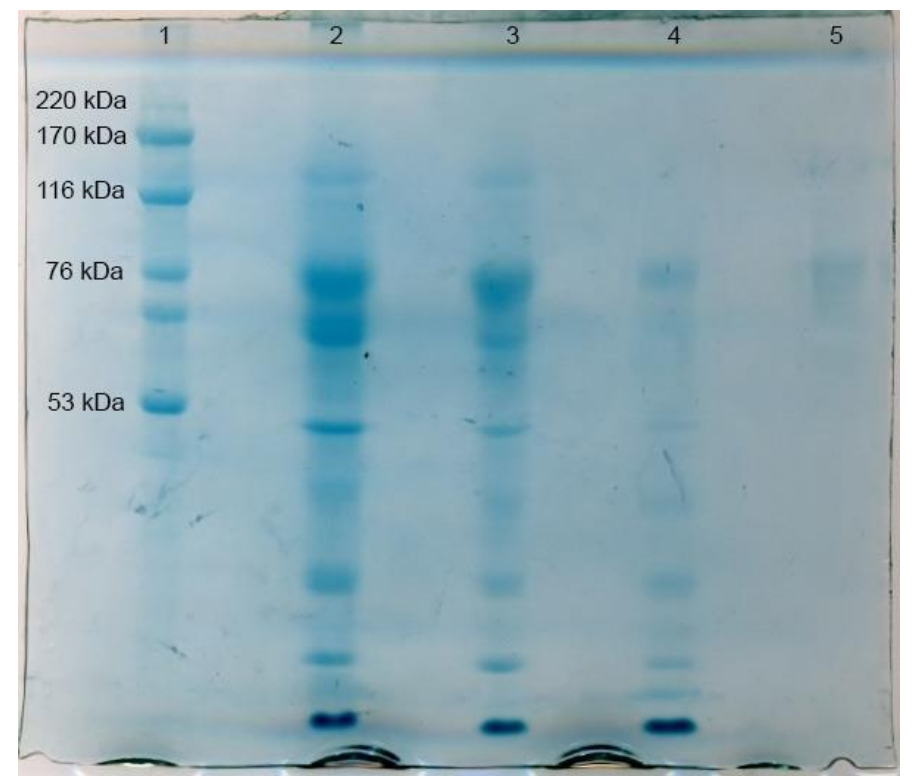

Figura 16 - Perfil eletroforético em gel de poliacrilamida 10\%. Padrão de massa molecular com marcadores de alto peso molecular (1); Extrato bruto (2); Ultrafiltrado membrana $100 \mathrm{kDa}$ (3); Concentrado membrana 30 kDa (4) e Pico 1S-200 (5).

A Figura 17 mostra a corrida eletroforética das etapas cromatográficas S-200 (2) e DEAE (3). É possível visualmente comparar a evolução da purificação. Observa-se na fração (2), apenas duas bandas com massa molar estimada de 76,58 kDa e 70,25 kDa. A fração (2) é referente a um único pico com atividade expresso no cromatograma (pico 1-DEAE) (Figura 15). Logo, infere-se que a coluna não foi capaz de separar as duas proteínas que aparecem na eletroforese. Por outro lado, ao analisar o zimograma (Figura 17B), observa-se uma única banda azul característica da atividade de $\beta$-galactosidase em X-Gal (39). Desta forma, não se pode descartar a presença de uma enzima dimérica. 


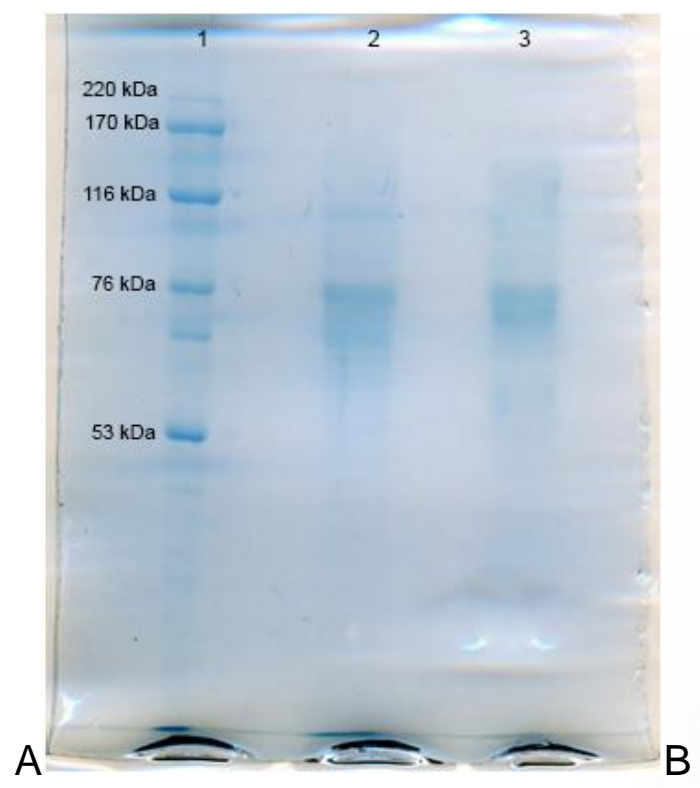

Figura 17 - A. Perfil eletroforético em condições desnaturante de gel de poliacrilamida (SDS-PAGE 10\%). Padrão de massa molecular (HMW) (1); Pico 1 S-200 e (2) e Pico1 DEAE (3). Figura B. Zimograma para atividade da $\beta$-galactosidase (fração pico $1 \mathrm{DEAE}$ ) em gel de atividade para enzima.

Dessa forma, a fração parcialmente purificada da $\beta$-galactosidase (Pico 1 DEAE) foi aplicada novamente na coluna de gel filtração, na qual foi eluída com um único pico correspondente a uma massa molecular de 74 kDa (Figura 18). Como o SDS-PAGE mostrou duas bandas correspondente a proteínas diferentes com massas moleculares de $76,58 \mathrm{kDa}$ e $70,25 \mathrm{kDa}$, sugere-se que na fração parcialmente purificada ainda existe a presença de duas proteínas com massa molecular muito próximas com características físico químicas semelhantes. Para a confirmação da purificação da fração, ou possível presença de uma $\beta$-galactosidase formada por dois monômeros, as amostras estão sendo submetidas à análise por espectrometria de massa. 


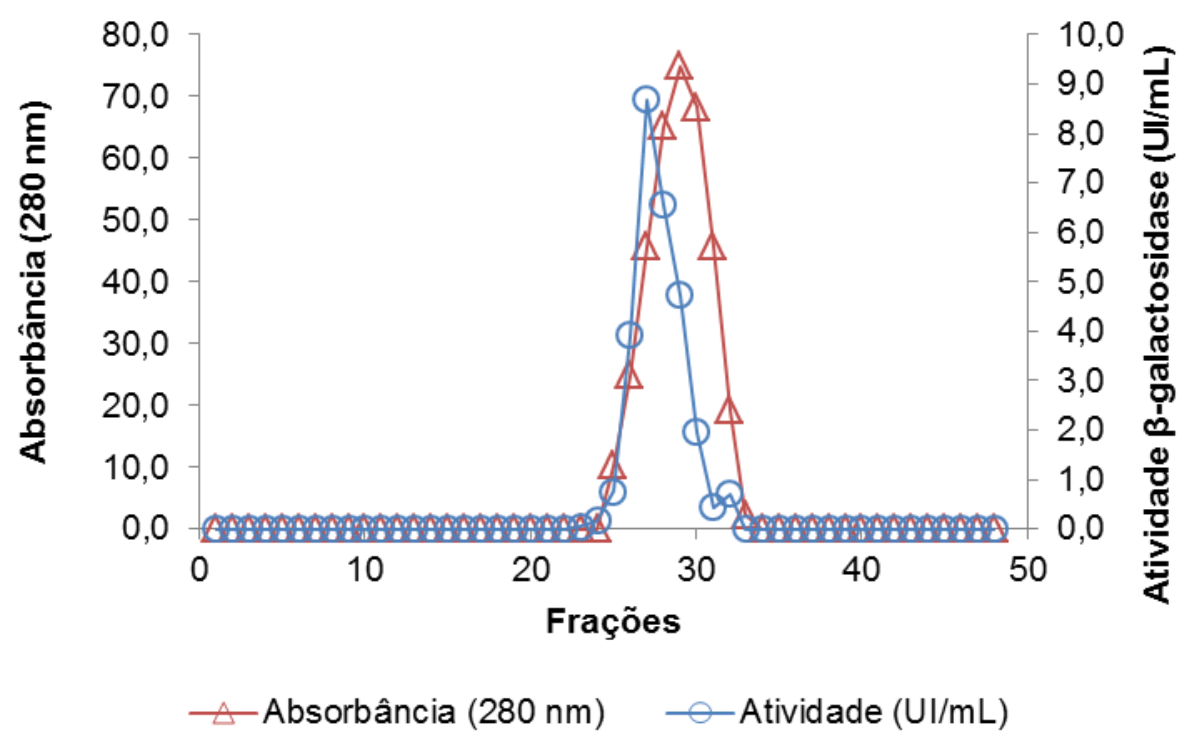

Figura 18 - Perfil cromatográfico de eluição do Pico 1 DEAE-FF em coluna de gel filtração Sephacryl S-200, utilizando tampão fosfato de sódio $0,1 \mathrm{M} \mathrm{pH} \mathrm{7,0} \mathrm{a} \mathrm{um} \mathrm{fluxo} \mathrm{de} 0,5 \mathrm{~mL} / \mathrm{min}$.

A presença de $\beta$-galactosidases diméricas assim como as massas moleculares observadas neste trabalho, são condizentes com as relatadas na literatura para diferentes $\beta$-galactosidases purificadas de fungos e bactérias. Isobe e colaboradores (2013), encontraram uma $\beta$-galactosidase fúngica de $140 \mathrm{kDa}$ com duas subunidades de $86 \mathrm{kDa}$ e $50 \mathrm{kDa}$ (120). Nagy et al. (2001), observaram que a $\beta$-galactosidase de Penicillium chrysogenum é uma enzima multimérica de aproximadamente 270 kDa composta por monômeros com 66 kDa (42). No estudo de Kong Fansi et al. (2014) o gene da $\beta$-galactosidase da bactéria Thermatoga naphthophila foi clonado e expresso em $E$. coli, onde a enzima recombinante purificada apresentou massa molecular de $70 \mathrm{kDa}$ (4). 


\subsection{CARACTERIZAÇÃO ENZIMÁTICA}

\subsubsection{Temperatura e pH}

A caracterização enzimática envolve diversos ensaios que visam elucidar as características das enzimas, principalmente aquelas que são promissoras do ponto de vista da sua aplicação industrial.

A determinação do efeito da temperatura e do $\mathrm{pH}$ sobre a amostra enzimática estabelece o tipo de processo industrial em que ela pode ser aplicada.

A influência do $\mathrm{pH}$ e da temperatura sobre $\beta$-galactosidase presente no extrato bruto e na fração parcialmente purificada está demonstrada na Figura 19 e Figura 20 respectivamente. A $\beta$-galactosidase apresentou maior atividade tanto para o extrato bruto quanto para Pico 1- DEAE no intervalo de $\mathrm{pH} 2,0-5,0$, sendo mais ativa em pH 3,0 (Figura 19). As $\beta$-galactosidases ácidas apresentam importância na área biotecnológica com aplicações no processamento de soro de leite e iogurtes (53). Além disso, há grande probabilidade de serem resistente às condições gástricas viabilizando o seu uso como suplemento alimentar para intolerantes a lactose (7).

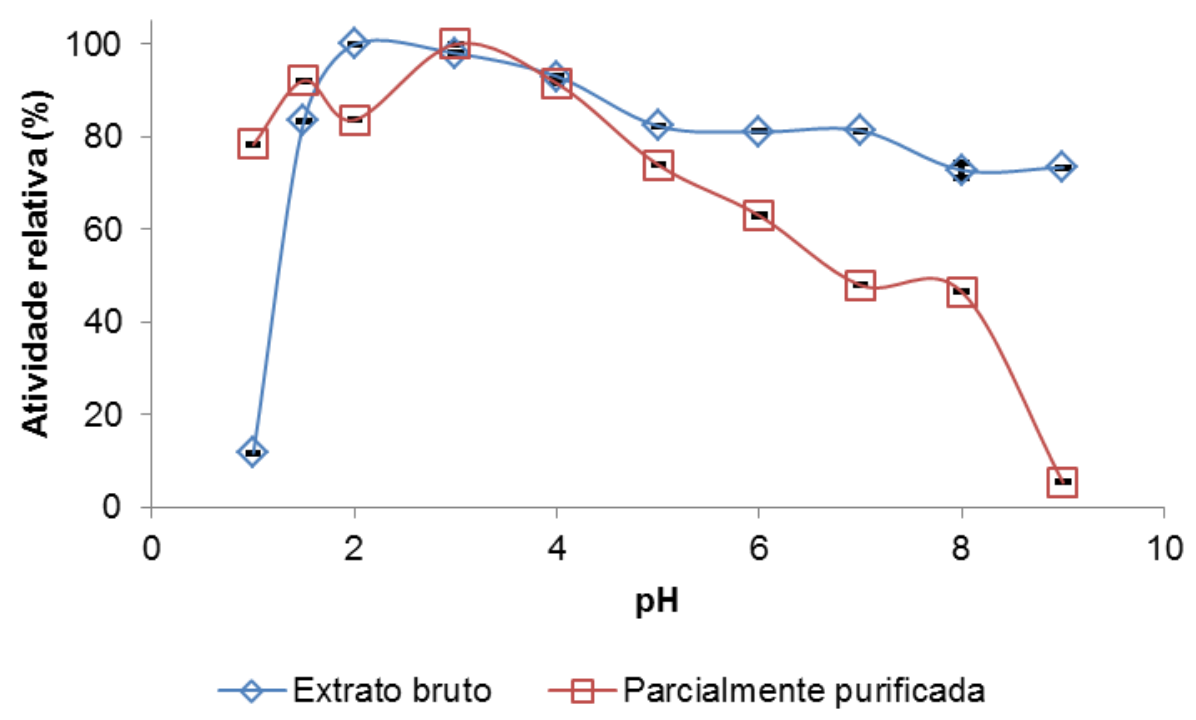

Figura 19 - Efeito do $\mathrm{pH}$ na atividade de $\beta$-galactosidase do extrato bruto e fração parcialmente purificada de $A$. foetidus. 
De um modo geral, o extrato bruto mostrou-se mais estável em relação a variação de $\mathrm{pH}$ do que a fração parcialmente purificada. Isto pode ser devido à presença de moléculas com atividade estabilizadora da atividade enzimática presente no extrato bruto que foram removidas durante o processo de purificação (Figura 19).

A eficiência das reações catalíticas são dependentes de uma temperatura ótima. Esta temperatura ótima influência diretamente a atividade da enzima, aumentando a velocidade de reação e, por consequência, a conversão do substrato em produtos. Em temperaturas muito superiores, ocorre a inativação enzimática, devido a desnaturação da enzima. Como consequência, o conhecimento da faixa de atividade ótima para cada enzima é fundamental para a otimização dos processos envolvendo reações enzimáticas (54).

A influência da temperatura na atividade da $\beta$-galactosidase está representada na Figura 20. A atividade manteve-se constante na faixa de temperatura de $20^{\circ} \mathrm{C}$ a $60^{\circ} \mathrm{C}$ indicando a presença de $\beta$-galactosidase com característica de interesse industrial, podendo ser aplicada para a produção de oligossacarideos e na hidrólise da lactose do leite.

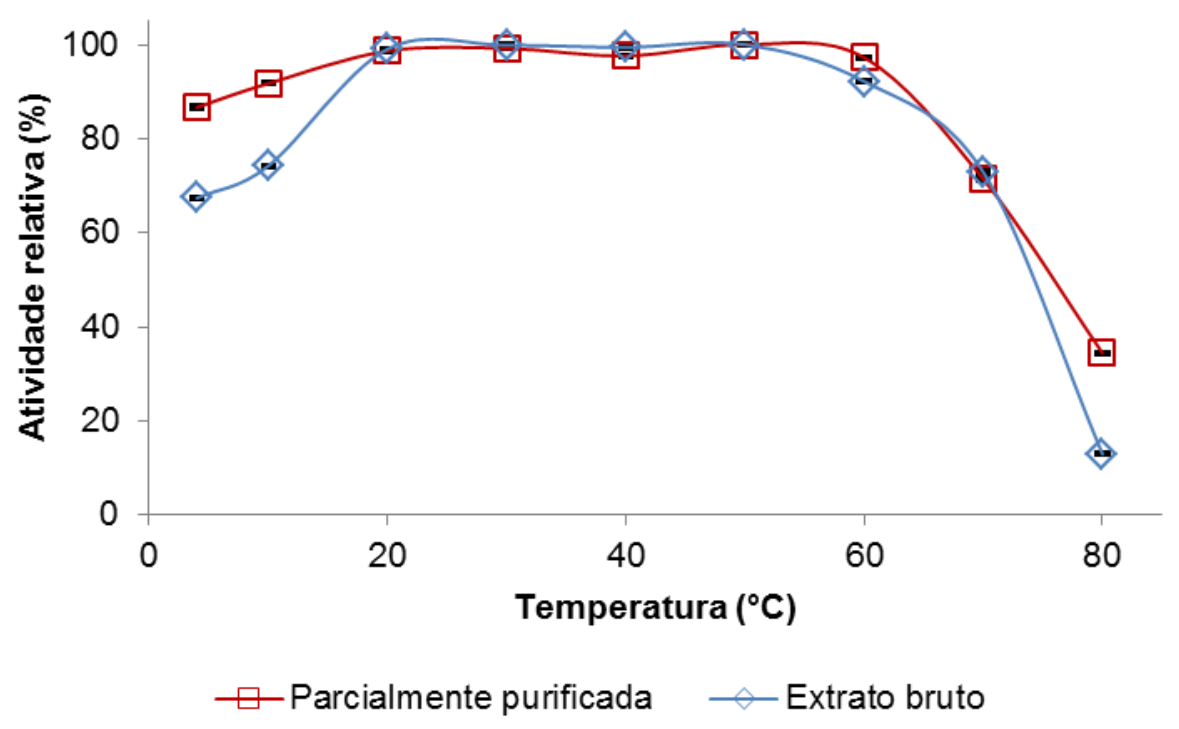

Figura 20 - Efeito da temperatura na atividade de $\beta$-galactosidase do extrato bruto e fração parcialmente purificada de $A$. foetidus. 
Estes resultados corroboram com a literatura, onde Lima et al. (1982) purificaram uma $\beta$-galactosidase de Aspergillus níger com temperatura ótima de $65^{\circ} \mathrm{C}$ e pH ótimo de 4,5 (126). Gekas e Leiva (1985) apresentaram um estudo em que $\beta$-galactosidase de Aspergillus niger foi caracterizada com um $\mathrm{pH}$ ótimo entre 3,0 e 4,0 e temperatura ótima entre 55 e $60^{\circ} \mathrm{C}$, já a $\beta$-galactosidase de Aspergillus oryzae indicaram $\mathrm{pH}$ ótimo 5,0 e temperatura ótima entre $50^{\circ} \mathrm{C}$ e $55^{\circ} \mathrm{C}$ (46). A presença de isoformas de $\beta$-galactosidase de Aspergillus carbonarius em meio líquido foi também descrita por O'Connell e Walsh (2008), apresentando valores de $\mathrm{pH}$ ótimo de 3,0 e 5,0 e temperatura ótima igual $55^{\circ} \mathrm{C}$ e $65^{\circ} \mathrm{C}(7)$.

\subsubsection{Termoestabilidade}

Visando aplicação da enzima em produtos alimentícios como leite e seus derivados, é interessante do ponto de vista industrial que a enzima seja estável tanto em temperaturas baixa (evitar proliferação de microrganismos e preservar nutrientes do leite), como em temperaturas elevadas (pasteurização). Dessa forma, prosseguiu-se com estudo de estabilidade da enzima nas temperaturas de $4^{\circ} \mathrm{C}$, $50^{\circ} \mathrm{C}$ e $70^{\circ} \mathrm{C}$ conforme mostrado na Figura 21.

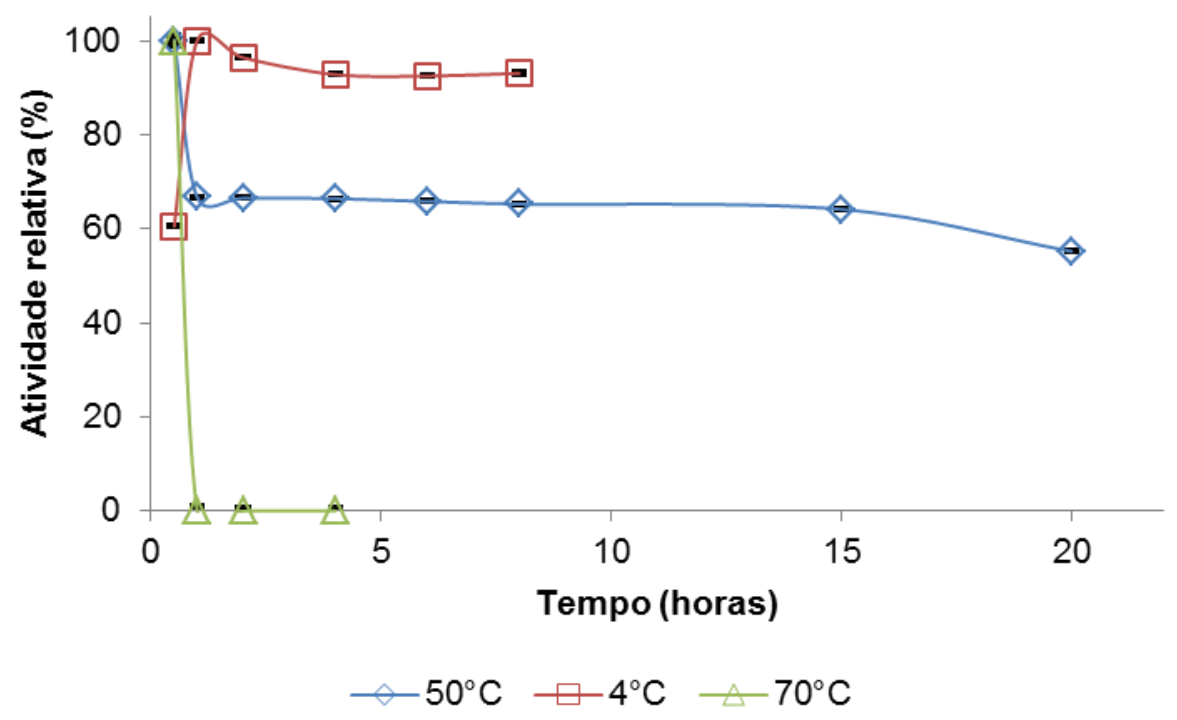

Figura 21 - Termoestabilidade da enzima parcialmente purificada nas temperaturas de $4^{\circ} \mathrm{C}, 50^{\circ} \mathrm{C}$ e $70^{\circ} \mathrm{C}$. 
A enzima parcialmente purificada foi submetida a ensaios de termoestabilidade nos quais foi dosada a atividade residual da $\beta$-galactosidase após um período de incubação. Após uma hora de incubação a $70^{\circ} \mathrm{C}$ a enzima não apresentou mais atividade, enquanto que quando incubada a $50^{\circ} \mathrm{C}$ por 1 hora a atividade enzimática foi reduzida em $33,3 \%$ a qual se manteve por aproximadamente 15 horas (Figura 21). Quando incubada a $4^{\circ} \mathrm{C}$ a atividade enzimática se manteve com o passar do tempo, indicando boa estabilidade da enzima nesta temperatura. Isso indica que seria viável a hidrólise da lactose a temperaturas de refrigeração, o que é interessante à nível industrial.

\subsubsection{Efeito de íons}

Além do $\mathrm{pH}$ e da temperatura, o efeito dos íons sobre a atividade da $\beta$ galactosidase foi avaliada.

A função de ativação ou inibição de compostos químicos ou íons constitui uma ferramenta de grande utilidade na caracterização da estrutura e nas possíveis interações que ocorrem no sítio ativo afetando o mecanismo de ação de enzimas. $\mathrm{Na}$ Tabela 10 está representada a influência de alguns íons no comportamento enzimático da $\beta$-galactosidase. 
Tabela 10 - Efeito de íons metálicos e EDTA na atividade da $\beta$-galactosidase parcialmente purificada de $A$. foetidus a partir do cultivo submerso com casca de soja

\section{Atividade relativa \%}

$1 \mathrm{mM}$

Controle

$\mathrm{MgSO}_{4}$

$\mathrm{AgNO}_{3}$

$\mathrm{FeSO}_{4}$

$\mathrm{CuSO}_{4}$

EDTA

$\mathrm{CaCl}_{2}$

$\mathrm{MgCl}_{2}$

$\mathrm{AlCl}_{3}$

$\mathrm{ZnSO}_{4}$

$\mathrm{KCl}$

$\mathrm{NaCl}$
$100 \pm 0,002$

$157,729 \pm 0,011^{*}$

$114,896 \pm 0,048$

$130,649 \pm 0,012^{*}$

$50,646 \pm 0,009^{*}$

$109,645 \pm 0,027$

$124,227 \pm 0,082$

$153,569 \pm 0,008^{*}$

$189,938 \pm 0,015^{*}$

$117,245 \pm 0,028$

$186,790 \pm 0,004^{*}$

$105,368 \pm 0,094$
$193,648 \pm 0,009^{*}$

$10 \mathrm{mM}$

$100 \pm 0,002$

$173,693 \pm 0,007^{\star}$

$0,000 \pm 0,011^{*}$

$140,865 \pm 0,013^{*}$

$67,532 \pm 0,021^{*}$

$116,958 \pm 0,012$

$80,328 \pm 0,017$

$174,817 \pm 0,011^{*}$

$210,848 \pm 0,004^{\star}$

$109,488 \pm 0,015$

$113,593 \pm 0,018$

$\left(^{*}\right)$ Indica diferença estatística no teste pareado LSD-Fisher. DP em relação à média de cada composto avaliado. 
A $\beta$-galactosidase foi ativada na presença de sulfato de magnésio (1 e $10 \mathrm{mM})$, sulfato de ferro (1 e $10 \mathrm{mM})$, cloreto de magnésio (1 e $10 \mathrm{mM}$ ), cloreto de alumínio (1 e $10 \mathrm{mM}$ ) e cloreto de potássio (1 e $10 \mathrm{mM}$ ) e inibida na presença de sulfato de cobre $(10 \mathrm{mM})$ e nitrato de prata $(10 \mathrm{mM})$.

Segundo a literatura, os íons $\mathrm{Mg}^{++}, \mathrm{Mn}^{++}, \mathrm{Co}^{++}$e $\mathrm{Ni}^{++}$são ativadores de $\beta$ galactosidase, enquanto que $\mathrm{Zn}^{++}, \mathrm{Eu}^{+++}$inativam a enzima e o EDTA mantém a atividade enzimática (127).

De acordo com Chuming Nie et.al (2013), a atividade de $\beta$-galactosidase produzida por lactobacilos em sistema recombinante em Pichia pastoris foi inibida por íons na concentração de $1 \mathrm{mM}$ e $5 \mathrm{mM} \mathrm{Ag}^{+}, \mathrm{Fe}^{++}, \mathrm{Cd}^{++}, \mathrm{Cu}^{++}$e induzida com $5 \mathrm{mM}$ dos íons $\mathrm{Mn}^{++}, \mathrm{Mg}^{++}$e $\mathrm{K}^{+}$aumentando a atividade enzimática em mais de $20 \%$ (38). Shaikh et al. (1999) relataram que a $\beta$-galactosidase de Rhizomucor sp. foi inibida por $\mathrm{Cu}^{++}$e induzida por $\mathrm{Mg}^{++}$(128). Segundo Robert (2015), a $\beta$-galactosidase de E.coli foi uma das primeiras enzimas a apresentar atividade estimulada por íons metálicos monovalentes (129).

\subsubsection{Especificidade ao substrato}

A especificidade da enzima foi avaliada por meio do ensaio de hidrólise de diversos substratos (Tabela 11). A enzima foi ativa na hidrólise de ONPG e na lactose. Para os demais substratos, a enzima mostrou pouca ou nenhuma atividade.

A $\beta$-galactosidase apresentou atividade majoritariamente sobre o ONPG e lactose, indicando que a enzima tem grande potencial para aplicação em indústrias de laticínios, que requerem enzimas sem atividade sobre outros substratos. 
Tabela 11 - Especificidade do substrato da $\beta$-galactosidase parcialmente purificada do Aspergillus foetidus.

\begin{tabular}{cc}
\hline Substrato & Atividade $(\mathrm{Ul} / \mathrm{mL})$ \\
ONPG & $22,125 \pm 0,018$ \\
Lactose & $5,622 \pm 0,002$ \\
CM-celulose & $0,253 \pm 0,004$ \\
PNPG & $0,043 \pm 0,005$ \\
\hline
\end{tabular}

\subsubsection{Parâmetros cinéticos Km e Vmáx}

Além da especificidade, os parâmetros cinéticos ( $\mathrm{Km}$ e Vmax) da $\beta$ galactosidase a $50^{\circ} \mathrm{C}$ para os substratos ONPG e lactose foram analisados de acordo com o modelo de Michaelis-Menten. Os valores das contanstes Km e Vmáx para ONPG foram de $1,84 \mathrm{mM}$ e $256,65 \mathrm{UI} / \mathrm{mL}$ respectivamente. Enquanto que para a lactose o valor de $\mathrm{Km}$ obtido foi de $40 \mathrm{mM}$ e Vmáx 2,86 UI/mL.

Quanto maior o valor de Km menor a afinidade da enzima pelo substrato. Por outro lado, o alto valor de Vmáx favorece a velocidade da reação. Sugere que a $\beta$ galactosidase parcialmente purificada de Aspergillus foetidus é eficiente assim como outras já reportadas na literatura, visando a aplicabilidade industrial destas enzimas. Shaichk et.al (1999), para $\beta$-galactosidase de Rizomucor encontraram para o substrato ONPG Km 1,32 mM e para lactose um Km de $50 \mathrm{mM}$ (128). O'Connel, (2008) isolaram duas $\beta$-galactosidase de Aspergillus carbonarius onde os valores de $\mathrm{Km}$ para substrato ONPG foram 2,23 mM e 0,56 mM e para lactose $\mathrm{Km}$ 82,68 e $308,9 \mathrm{mM}$. Os valores de Vmáx para estas mesmas enzimas foram de 1,20 UI/mL e $75 \mathrm{Ul} / \mathrm{mL}$ para ONPG e $146 \mathrm{UI} / \mathrm{mL}$ e 9,3 Ul/mL para lactose (7). Isobe et al. (2013) encontraram para $\beta$-galactosidase de Theratosphaeria acidotherma, um $\mathrm{Km}$ de $0,19 \mathrm{mM}$ e para ONPG (120). Shane O'Connel (2010) para $\beta$-galactosidase de uma cepa de Aspergillus niger encontraram para substrato ONPG Km de 1,74 mM e Vmáx de $137 \mathrm{UI} / \mathrm{mL}$ e para lactose Km de 48,07mM e Vmáx de $16 \mathrm{UI} / \mathrm{mL}$ (130). 


\subsection{APLICABILIDADE}

\subsubsection{Hidrólise da lactose do leite}

A lactose é um dissacarídeo que, quando submetido à ação da enzima $\beta$ galactosidase é quebrado em dois monossacarídeos, a glicose e a galactose. Desta forma, considerando que a concentração de glicose é inversamente proporcional à concentração de lactose presente na amostra, neste trabalho, a porcentagem de hidrólise no leite foi medida pela concentração de glicose.

A concentração de lactose na amostra do leite foi de 5\%. Portanto, se toda a amostra for hidrolisada a concentração máxima de glicose será de 2,5\% (131).

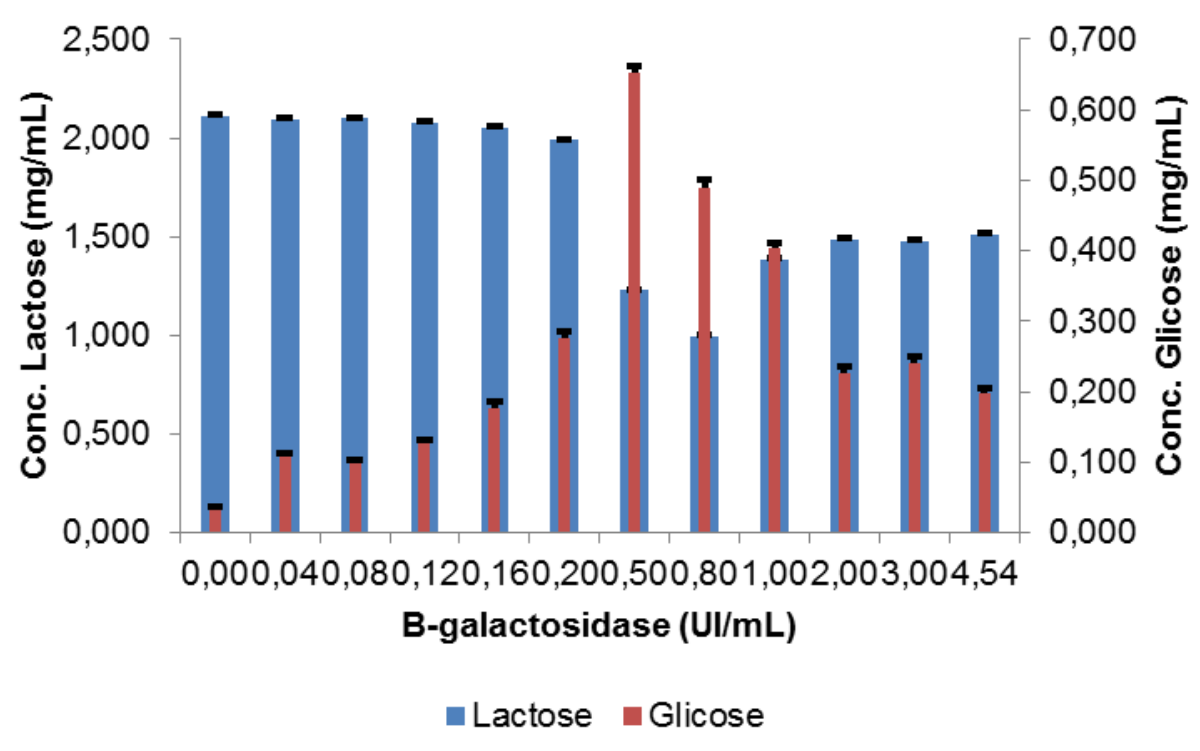

Figura 22 - Conversão da lactose em glicose em diferentes concentrações de enzima.

Neste trabalho com $0,5 \mathrm{UI} / \mathrm{mL}$ de $\beta$-galatosidase $50 \%$ da lactose foi hidrolisada. Porém, é considerado satisfatório para intolerantes a lactose uma hidrólise de $90 \%$ de lactose, em um produto que contem cerca de $5 \mathrm{~g}$ (Hernandez 1982). Dentro das condições industriais, Prenosil et al. (1987) consideram a hidrólise de 75 - $85 \%$ como sendo excelente.

No caso específico da $\beta$-galactosidase de A.foetidus, a taxa de hidrólise menor, pode ser justificada pelo fato da enzima ter sido utilizada em $\mathrm{pH}$ neutro (leite) 
e não em seu pH ótimo ácido. Optou-se por utilizar a enzima em um $\mathrm{pH}$ neutro devido a floculação do leite em $\mathrm{pH} 3,0$, o que inviabilizou o experimento. Outro fator que pode ter influenciado foi o tempo de reação que foi de apenas $30 \mathrm{~min}$. Mesmo assim apesar das limitações expostas, uma taxa de hidrolise de $20 \%$ já foi considerada satisfatória para diminuir efeitos de arenosidade do doce de leite (132).

Na Figura 22, também podemos observar a diminuição de lactose e aumento do produto glicose até formar um platô. Sabendo-se que a estequiometria da reação é de 1:1, o aumento da glicose indica um aumento de galactose. A galactose ocupa competitivamente o sitio ativo da $\beta$-galactosidase resultando na diminuição da atividade enzimática.

Um dos fatores mais importantes, que limita o rendimento da $\beta$-galactosidase é a inibição competitiva que exercem os produtos de reação, glicose e galactose (53). A galactose é o inibidor mais importante para a $\beta$-galactosidase, embora a força da potência inibitória dependa da origem da enzima (54). Esse monossacarídeo possui maior capacidade de inibição da $\beta$-galactosidase de Aspergillus oryzae do que a $\beta$-galactosidase proveniente de Kluyveromicyes sp.(54).

\subsubsection{Simulação da $\beta$-galactosidase em pH gástrico}

Visando uma possível aplicabilidade da $\beta$-galactosidase como suplemento digestivo para indivíduos intolerantes a lactose, realizou-se um teste de simulação da enzima em condições gástricas.

Para terapêutica ser biodisponível por via oral após administração a enzima precisa ser estável às condições ácidas e enzimáticas do estômago. Portanto, testou-se a estabilidade da enzima $\beta$-galactosidase em Fluído Gástrico Simulado (SGF), por 2 horas conforme a Farmacopeia Brasileira $5^{\underline{a}}$ edição (109). 


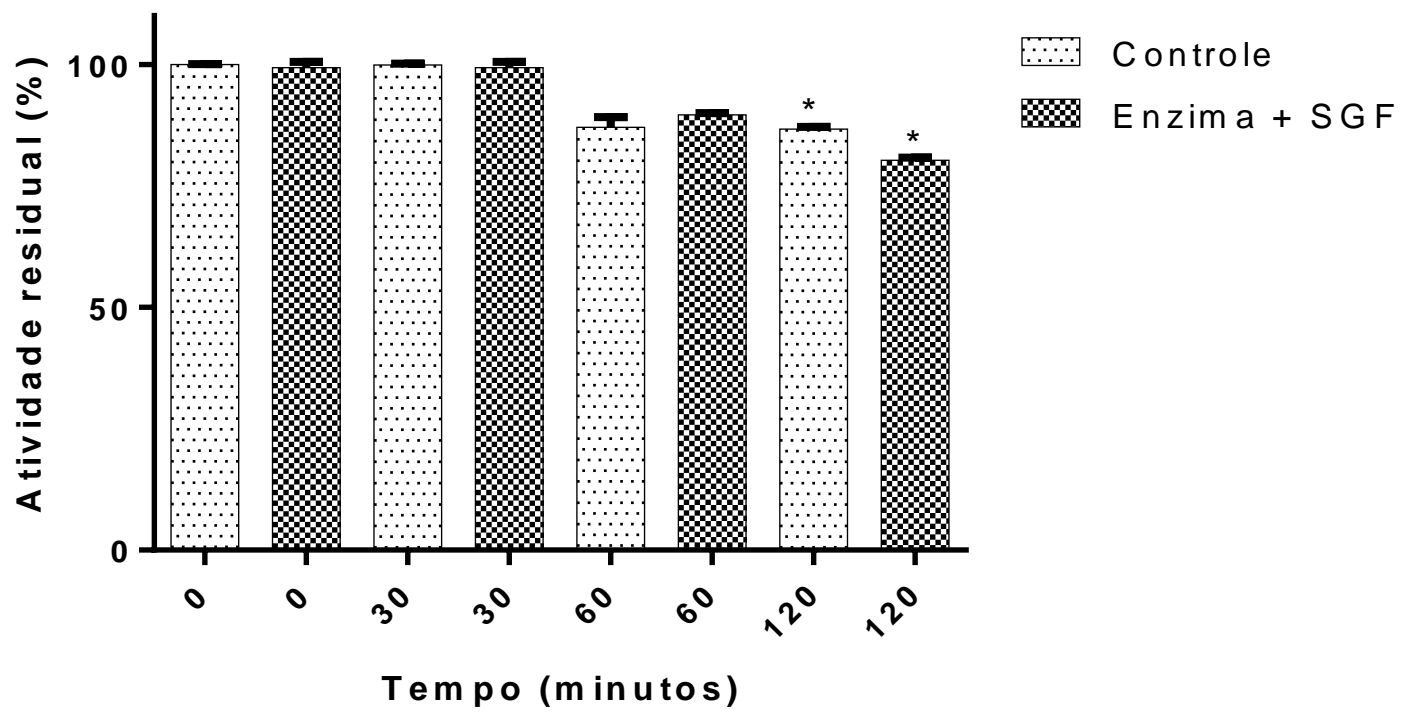

Figura 23 - Efeito in vitro da enzima $\beta$-galactosidase em simulação das condições gástricas. Controle: enzima incubada com tampão pH 2,0. Enzima + SGF ( $\mathrm{NaCl} 2 \%$, pepsina bovina 0,32\% e $\mathrm{HCl} 7 \%)$. *Indica diferença estatística no teste ANOVA teste Tukey com nível de significância $(p<0,05)$.

A atividade enzimática é representada como um valor de porcentagem (\%) relativa a atividade exibida pelo controle. Onde $100 \%$ é equiparado a $0,5 \mathrm{UI} / \mathrm{mL}$.

$\mathrm{Na}$ figura Figura 23, observa-se que $\beta$-galactosidase obteve nível de atividade residual de $80 \%$ quando submetida à simulação do fluído gástrico durante 2 horas. A perda mínima da atividade pode ser atribuída a instabilidade enzimática em pH baixo ao longo do tempo. No estudo de O'Connel et al. (2008), quando a $\beta$ galactosidase de Aspergillus carbonarius foi submetida a condições gástricas, reteve $70 \%$ de atividade residual após 2 horas de incubação (7).

É importante que se tenha uma enzima resistente ao pH ácido do estômago, durante aproximadamente 90 minutos (tempo em que 0 ambiente gástrico permanece tamponado em $\mathrm{pH}$ ácido) de forma que chegue ao intestino (local de hidrólise da lactose) com sua atividade catalítica preservada.

A maioria das preparações comerciais não satisfazem plenamente os critérios para elaboração de um suplemento ideal. Necessitam de revestimento entérico para 
proteger a enzima suplementar dos efeitos do baixo $\mathrm{pH}$ gástrico e necessitam de dosagem mais elevadas para se obter a hidrólise necessária (34).

O'Connel et al. (2006), investigaram in vitro se os produtos comercializados como suplemento enzimático de $\beta$-galactosidase eram compatíveis com as condições digestivas, onde concluíram que a maioria delas foram sensíveis ao $\mathrm{pH}$ ácido entérico apresentando atividade enzimática de 65\%, após exposição as condições do trato digestivo. Ainda, os pesquisadores alertaram que para se ter o grau de hidrólise necessária para uma refeição à base de produtos lácteos, a quantidade de cápsulas ingerida teria que ser aumentada em relação a recomendada pelo fabricante.

Dessa forma, conseguir estabilidade enzimática da $\beta$-galactosidase in vitro frente à condição hostil gástrica é relevante tanto para adequar a hidrólise ótima da lactose in vivo, quanto para se alcançar preparações comerciais de $\beta$-galactosidase (livre de revestimento) economicamente mais viável. 


\section{CONCLUSÃO}

- O fungo filamentoso $A$. foetidus apresentou os melhores resultados para a produção enzimática, seguido dos fungos Penicillium felutanum e Penicillium variabile dentre os fungos filamentosos do cerrado centro-oeste brasileiro estudados neste trabalho.

- O meio líquido contendo casca de soja e meio mínimo induziu uma maior expressão desta enzima por este microrganismo.

- As melhores condições para a produção de $\beta$-galactosidase pelo fungo $A$. foetidus foram a um $\mathrm{pH}$ inicial do meio igual a 7,0, velocidade de agitação de 120 rpm, à temperatura de $28^{\circ} \mathrm{C}$ com um tempo de fermentação de 168 horas.

- A $\beta$-galactosidase produzida foi parcialmente purificada, apresentando duas bandas em gel desnaturante de eletroforese com peso molecular estimado de 76,58 kDa e 70,25 kDa. Porém, não foi possível concluir se estas bandas representam uma enzima dimérica ou se são duas enzimas com peso molecular muito próximos.

- A $\beta$-galactosidase parcialmente purificada apresentou pH ótimo igual a 3,0 e termoestabilidade em temperatura ótima de $50{ }^{\circ} \mathrm{C}$ por 15 horas.

- A $\beta$-galactosidase apresentou um grau de hidrólise satisfatório para ser empregado no processamento de produtos lácteos, a fim de minimizar problema de cristalização.

- A enzima foi resistente por 2 horas em ensaio de simulação gástrica, o que é interessante para indústria no que tange sua utilização como suplemento alimentar.

Estes resultados são bastante promissores para o desenvolvimento de $\beta$ galactosidase fúngica em grande escala, a partir de resíduo de baixo custo com potencial aplicação em processos industriais. 


\section{PERSPECTIVAS E SUGESTÕES}

- Confirmar a identidade da $\beta$-galctosidase através da análise de peptídios por espectrometria de massa.

- Continuidade de testes de aplicabilidade.

- Explorar A. foetidus, como candidato a manipulação genética (biologia molecular) visando aumento de rendimento. 


\section{REFERÊNCIAS}

1. Tomar BS. Lactose intolerance and other disaccharidase deficiency. Indian $\mathrm{J}$ Pediatr. 2014;81(9):876-80.

2. Swaguerty D WA, Klein RM. Lactose Intolerance. Am Fam Physician. 2002;65.

3. Ruiz-Matute Al, Corzo-Martínez M, Montilla A, Olano A, Copovi P, Corzo N. Presence of mono-, di- and galactooligosaccharides in commercial lactose-free UHT dairy products. J Food Compos Anal. 2012;28 (2):164-9.

4. Kong F, Wang Y, Cao S, Gao R, Xie G. Cloning, purification and characterization of a thermostable $\beta$-galactosidase from Thermotoga naphthophila RUK-10. Process Biochem. 2014;49 (5):775-82.

5. Jurado E, Camacho F, Luzón G, Vicaria JM. A new kinetic model proposed for hydrolysis of lactose by $\beta$-galactosidase from Kluyveromyces fragilis. Enzyme Microb Technology. 2002;31(3):300-9.

6. Shuber LCL CM, Bonfim TMB, et al. Isolamento e seleção de fungos produtores de $\beta$-galactosidase. Evidência. 2012;12(1):19-40.

7. O'Connell S, Walsh G. Application relevant studies of fungal $\beta$-galactosidases with potential application in the alleviation of lactose intolerance. Appl Biochem Biotechnol. 2008;149 (2):129-38.

8. Dragosits M, Pflugl S, Kurz S, Razzazi-Fazeli E, Wilson IB, Rendic D. Recombinant Aspergillus beta-galactosidases as a robust glycomic and biotechnological tool. Appl Microbiol Biotechnol. 2014;98 (8):3553-67.

9. Santos A, Ladero M, Garcia-Ochoa F. Kinetic modeling of lactose hydrolysis by a $\beta$-galactosidase from Kluyveromices fragilis. Enzyme Microb Technol. 1998;22(7):558-67. 
10. Vénica Cl, Bergamini CV, Rebechi SR, Perotti MC. Galacto-oligosaccharides formation during manufacture of different varieties of yogurt. Stability through storage. LWT - Food Sci Technol. 2015;63 (1):198-205.

11. Langarica-Fuentes A, Handley PS, Houlden A, Fox G, Robson GD. An investigation of the biodiversity of thermophilic and thermotolerant fungal species in composts using culture-based and molecular techniques. Fungal Ecol. 2014;11:13244.

12. Gomes E, Guez MAU, Martin N, da Silva R. Enzimas termoestáveis: fontes, produção e aplicação industrial. Qim Nova. 2007;30(1):136-145.

13. Lopes F. Produção e Análise de Metabólitos Secundários de Fungos Filamentosos [mestrado]. Porto Alegre Universidade Federal do Rio Grande do Sul; 2011.

14. Felberg I. Manual de produção de extrato de soja para agroindústria de pequeno porte. Rio de Janeiro: Embrapa Agroindustria de Alimentos. 2005.

15. Jegannathan KR, Nielsen $\mathrm{PH}$. Environmental assessment of enzyme use in industrial production-a literature review. J Cean Prod. 2013;42:228-40.

16. Cruz EA, Melo MC, Santana NB, Franco M, de Santana RSM, Santos LS, et al. Alpha-Amylase production by Aspergillus niger in cassava peels waste. J Health Sci. 2011;13(4):245-9.

17. Moreira S. Xilanases produzidas por Aspergillus terreus: Caracterização, degradação de biomassa lignocelulósica e efeito de compostos fenólicos [Doutorado]. Brasília: Universidade de Brasília; 2013.

18. Jaramillo P. Produção, Caracterização e Aplicação Biotecnológica de pectinases produzidas pelo fungo Aspergillus oryzae cultivado em casca de maracujá-amarelo [Doutorado]. Brasília: Universidade de Brasília; 2014.

19. Moreira LR, Ferreira GV, Santos SST, Ribeiro APS, Siqueira FG, Ferreira Filho EX. The hydrolysis of agro-industrial residues by holocellulose-degrading enzymes. Braz J Microbiol. 2012;43(2):498-505. 
20. Trevisan A. Influência de diferentes concentrações de enzimas lactase e temperaturas sobre a hidrólise da lactose em leite pasteurizado [Mestrado]. Santa Maria, RS: Universidade Federal de Santa Maria 2008.

21. Bravim M. Intolerância à lactose. São Paulo: Federação Brasileira de Gastroenterologia. 2015 [cited 2015 13/11/2015]. Disponível em: http://www.fbg.org.br/Textos/2182/Intoler\%C3\%A2ncia-\%C3\%A0-Lactose.

22. FDA. Problems Digesting Dairy Products? Food and Drug Administration; 2009 [cited 23/11/15]. Disponível em: http://www.fda.gov/forconsumers/consumerupdates/ucm094550.htm\#intolerance.

23. Fischer J. Hidrólise de lactose por B-galactosidase de Aspergillus oryzae imobilizada em reator de leito fixo [Mestrado]. Uberlândia: Universidade Federal de Uberlândia; 2010.

24. Brasil. Intolerância à lactose. Brasília. Ministério da Saúde: Secretaria de saúde. 2005. Disponível em: bvsms.saude.gov.br/bvs/dicas/88lactose.html.

25. Pretto FM, Silveira TRd, Menegaz V, Oliveira JRd. Má absorção de lactose em crianças e adolescentes: diagnóstico através do teste do hidrogênio expirado com o leite de vaca como substrato. J ped.2002; 78 (3): 213-218.

26. Back D. Desenvolvimento de queijo minas frescal probiótico com teor reduzido de lactose [Mestrado]. Santa Maria - RS: Universidade Federal de Santa Maria; 2011.

27. Mattar R, Mazo D. Intolerância à lactose: mudança de paradigmas com a biologia molecular. Rev Assoc Med Bras. 2010;56(2):230-6.

28. Vandenplas Y. Lactose intolerance. Asia Pac J Clin Nutr. 2015;24 Suppl 1:S9-13.

29. Faedo R, Brião VB, Castoldi S. Obtenção de leite com baixo teor de lactose por processos de separação por membranas associados à hidrólise da enzima. Revista CIATEC-UPF. 2013;5(1). 
30. Longo G. Influência da adição de lactase na produção de iogurtes [Mestrado]. Curitiba: Universidade Federal do Paraná; 2006.

31. Diekmann L, Pfeiffer K, Naim HY. Congenital lactose intolerance is triggered by severe mutations on both alleles of the lactase gene. BMC gastroenterology. $2015 ; 15$.

32. Andrade A. Estudo da fermentação simultânea à hidrólise, de soro de queijo, utilizando lactase e Saccharomyces cerevisiae [Mestraddo]. Uberlândia: Universidade Federal de Uberlândia : 2005.

33. Brasil. Portaria n.29, de 13 de janeiro de 1998. Aprova o regulamento técnico referente a alimentos para fins especiais. 1998. Disponível em: portal.anvisa.gov.br.

34. O'Connell S, Walsh G. Physicochemical characteristics of commercial lactases relevant to their application in the alleviation of lactose intolerance. App Biochem Biotechnol. 2006;134(2):179-91.

35. Lombard V. et al. The carbohidrate-active enzymes database (CAZy). 2006 [18/01/2016]. Disponível em : htt//www.cazy.org.

36. Martins AR, Burkert CAV. Revisão: Galacto-oligossacarídeos (GOS) e seus efeitos prebióticos e bifidogênicos. Braz J Food Technol. 2009;12(03):230-40.

37. Campello G. Imobilização de B-galactosidase (Lactozym) em Eupergit e sua caracterização [Mestrado]. Rio Grande: Universidadefederal do Rio Grande; 2010.

38. Nie $\mathrm{C}$, Liu $\mathrm{B}$, Zhang $\mathrm{Y}$, Zhao G, Fan $X$, Ning $X$, et al. Production and secretion of Lactobacillus crispatus beta-galactosidase in Pichia pastoris. Protein Expr Purif. 2013;92(1):88-93.

39. Kishore D, Kayastha AM. A beta-galactosidase from chick pea (Cicer arietinum) seeds: its purification, biochemical properties and industrial applications. Food Chem. 2012;134(2):1113-22. 
40. Panesar PS, Panesar R, Singh RS, Kennedy JF, Kumar H. Microbial production, immobilization and applications of $\beta$-D-galactosidase. J Chem Technol Biotechnol. 2006;81(4):530-43.

41. Husain Q. Beta galactosidases and their potential applications: a review. Crit Rev Biotechnol. 2010;30(1):41-62.

42. Nagy Z, Kiss T, Szentirmai A, Biro S. Beta-galactosidase of Penicillium chrysogenum: production, purification, and characterization of the enzyme. Protein Expr Purif. 2001;21(1):24-9.

43. Vera C, Guerrero C, Illanes A. Determination of the transgalactosylation activity of Aspergillus oryzae beta-galactosidase: effect of $\mathrm{pH}$, temperature, and galactose and glucose concentrations. Carbohydr Res. 2011;346(6):745-52.

44. Sen S, Ray L, Chattopadhyay P. Production, purification, immobilization, and characterization of a thermostable beta-galactosidase from Aspergillus alliaceus. Appl Biochem Biotechnol. 2012;167(7):1938-53.

45. Lisboa CR, Costa F, Burkert J, Burkert CAV. Síntese de galactooligossacarídeos a partir de lactose usando $\beta$-galactosidase comercial de Kluyveromyces lactis. Braz J Food Technol. 2012;15(1).

46. Gekas V, Leiva L. Hydrolysis of lactose: A literature review. Process Biochemistry. 1985;20 (1):2-12.

47. Nath A, Mondal S, Chakraborty S, Bhattacharjee C, Chowdhury R. Production, purification, characterization, immobilization, and application of $\beta$-galactosidase: a review. Asia Pac J Chem Eng. 2014;9(3):330-48.

48. Matthews BW. The estructure of E.coli $\beta$-galactosidase. Comptes rendus, Biologies. 2005;328:549-56.

49. Silva NKG, Barbosa RC, Coutinho Filho U, Cardoso VL. Crescimento celular e produção de beta-galactosidase e celulase por Aspergillus niger em soro de leite. VIII Congresso brasileiro de engenharia química em iniciaçào científica; 2009. 
50. Guerrero C, Vera C, Conejeros R, Illanes A. Transgalactosylation and hydrolytic activities of commercial preparations of beta-galactosidase for the synthesis of prebiotic carbohydrates. Enzyme Microb Technol. 2015;70:9-17.

51. Cavalcante Braga AR, Manera AP, da Costa Ores J, Sala L, Maugeri F, Juliano Kalil S. Kinetics and thermal properties of crude and purified $\beta$-galactosidase with potential for the production of galactooligosaccharides. Food Technol Biotechnol. 2013;51(1):45-52.

52. Matioli G, Moraes FFd, Zanin GM. Operational stability and kinetics of lactose hydrolysis by b-galactosidase from Kluyveromyces fragilis. Acta Sci, Health Sci. 2003;25(1):7-12.

53. Antonieta Rodriguez V, Fermín Cravero B, Alonso A. Proceso de elaboración de yogur deslactosado de leche de cabra. Food Sci Technol 2008;28:109-15.

54. Carminatti C. Ensaios de hidrólise enzimática da lactose em reator a membrana utilizando Beta-galactosidase Kluyveromyces lactis [Mestrado]. Santa Catarina: Universidade Federal de Santa Catarina; 2001.

55. Oliveira CCM. Produção de B-galactosidase por levedura recombinante Desenvolvimento de um sistema de produção estável [Mestrado]. Braga, Portugal: Universidade do Minho;2005.

56. Fagnani R CP. Alterações nadensidade e crioscopia do leite pela adição de diferentes concentrações de citrato e fortificante. Rev Caat. 2014;27(4).

57. Milanezi N. Purificação e caracterização de uma endo-1,4-B-xilanase produzida por Aspergillus niger com características de interesse industrial [Mestrado]. Brasília - DF: Universidade de Brasília;2010.

58. Santos R, Simiqueli APR, Pastore GM. Production of galactooligosaccharide by Scopulariopis sp. Food Sci Technol. 2009;29(3):682-9.

59. Bassetto RZ, Cruz MCR, de Almeida MM, Chiquetto NC. Caracterização da produção de galactooligossacarideos por fermentação sequencial Evidência-Ciênc Biotecnol. 2014;14(1):57-68. 
60. Rossetto BP, Zanin GM, Moraes FFd. Determinação da Atividade da Enzima B-galactosidase por Lactose do Soro de Queijo. Biochem Biotechnol Reports. $2012 ; 1(2)$.

61. Gosling A, Stevens GW, Barber AR, Kentish SE, Gras SL. Recent advances refining galactooligosaccharide production from lactose. Food Chem. 2010;121(2):307-18.

62. Fuhrmann G, Leroux JC. Improving the stability and activity of oral therapeutic enzymes-recent advances and perspectives. Pharmaceutical research. 2014;31(5):1099-105.

63. Wang H, Luo H, Bai Y, Wang Y, Yang P, Shi P, et al. An acidophilic betagalactosidase from Bispora sp. MEY-1 with high lactose hydrolytic activity under simulated gastric conditions. J Agric Food Chem. 2009;57(12):5535-41.

64. Chapla D, Divecha J, Madamwar D, Shah A. Utilization of agro-industrial waste for xylanase production by Aspergillus foetidus MTCC 4898 under solid state fermentation and its application in saccharification. Biochem Eng J. 2010;49(3):3619.

65. Kirk O, Borchert TV, Fuglsang CC. Industrial enzyme applications. Curr Opin Biotechnol. 2002;13(4):345-51.

66. Marco J. Produção e caracterização de mananase de Aspergillus foetidus cultivado em casca do grão da soja [Mestrado]. Brasília: Universidade de Brasília 2014.

67. Esposito E, Azevedo JL. Fungos: uma introdução à biologia, bioquímica e biotecnologia. 2 ed. Caxias do Sul : Educs;2010.

68. Galvagno M, Forchiassin F. Fisiologia dos fungos: Nutrição e metabolismo. In: Fungos: Uma introdução a biologia, bioquímica e biotecnologia. Caxias do Sul;2010. p. 125-64. 
69. Suryanarayanan TS, Thirunavukkarasu N, Govindarajulu MB, Sasse F, Jansen R, Murali TS. Fungal endophytes and bioprospecting. Fungal Biol Rev. 2009;23(1-2):9-19.

70. Arantes V, Milagres AM. Relevance of low molecular weight compounds produced by fungi and involved in wood biodegradation. Qim Nova. 2009;32(6):158695.

71. Garbeva P, Van Veen J, Van Elsas J. Microbial diversity in soil: selection of microbial populations by plant and soil type and implications for disease suppressiveness. Annu Rev Phytopathol. 2004;42:243-70.

72. Kumar R, Singh S, Singh OV. Bioconversion of lignocellulosic biomass: biochemical and molecular perspectives. J Ind Microbiol Biotechnol. 2008;35(5):37791.

73. Kumar CG, Mongolla P, Joseph J, Nageswar Y, Kamal A. Antimicrobial activity from the extracts of fungal isolates of soil and dung samples from Kaziranga National Park, Assam, India. J Med Mycol. 2010;20(4):283-9.

74. Sun R, Gao Y-X, Shen K-Z, Xu Y-B, Wang C-R, Liu H-Y, et al. Antimicrobial metabolites from the aquatic fungus Delitschia corticola. Phytochem Lett. $2011 ; 4(2): 101-5$.

75. Brakhage AA, Schroeckh V. Fungal secondary metabolites - strategies to activate silent gene clusters. Fungal Genet Biol . 2011;48(1):15-22.

76. Keller NP, Turner G, Bennett JW. Fungal secondary metabolism - from biochemistry to genomics. Nat Rew Microbiol. 2005;3(12):937-47.

77. Hoffmeister D, Keller NP. Natural products of filamentous fungi: enzymes, genes, and their regulation. Nat Prod Rep. 2007;24(2):393-416.

78. Souza Moreira LR, Carvalho Campos M, Siqueira PH, Silva LP, Ricart CA, Martins PA, et al. Two beta-xylanases from Aspergillus terreus: characterization and influence of phenolic compounds on xylanase activity. Fungal Genet Biology. 2013;60:46-52. 
79. Ferreira Filho EX, Puls J, Coughlan MP. Biochemical characteristics of two endo- $\beta-1$, 4-xylanases produced by Penicillium capsulatum. J Ind Microbiol. $1993 ; 11(3): 171-80$.

80. Manera AP, Meinhardt S, Kalil SJ. Purificação de amiloglicosidase de Aspergillus niger. Semina: Ciênc Agr. 2011;32(2):651-58.

81. Adrio JL, Demain AL. Fungal biotechnology. Int Microbiol : 2003;6(3):191-9.

82. Berdy J. Bioactive microbial metabolites. J Antibiot. 2005;58(1):1-26.

83. Hu HL, van den Brink J, Gruben BS, Wösten HAB, Gu JD, de Vries RP. Improved enzyme production by co-cultivation of Aspergillus niger and Aspergillus oryzae and with other fungi. Int Biodeterior Biodegradation. 2011;65(1):248-52.

84. Tarskin E SE. Polygalacturonases produced under solid state and submerged fermentation conditions by two strains of Aspergillus foetidus. Turk $\mathrm{J}$ Biochem. 2008;33(4):190-6.

85. Liu CQ, Chen QH, Cheng QJ, Wang JL, He GQ. Effect of cultivating conditions on alpha-galactosidase production by a novel Aspergillus foetidus ZU-G1 strain in solid-state fermentation. Journal of Zhejiang University Science B. 2007;8(5):371-6.

86. Ferracin LM, Frisvad JC, Taniwaki MH, lamanaka BT, Sartori D, Schapovaloff $\mathrm{ME}$, et al. Genetic relationships among strains of the Aspergillus niger aggregate. Braz Arch Biol and Technol. 2009;52:241-8.

87. Takahashi JA, Lucas EMF. Occurrence and structural diversity of fungal metabolites with antibiotic activity. Quim Nova. 2008;31(7):1807-13.

88. Borzani W, Schmidell W, Lima UdA, Aquarone E. Biotecnologia industrial: fundamentos. São Paulo: Edgard Blücher. 2001;1:254.

89. Meyer V. Genetic engineering of filamentous fungi--progress, obstacles and future trends. Biotechnol Adv. 2008 ;26(2):177-85. 
90. Soccol CR, Vandenberghe LP. Overview of applied solid-state fermentation in Brazil. Biochem EngineerJ. 2003;13(2):205-18.

91. Aguiar A, Ferraz A. Mecanismos envolvidos na biodegradação de materiais lignocelulósicos e aplicações tecnológicas correlatas. Quim Nova. 2011;34(10):172938.

92. Siqueira FG, de Siqueira EG, Jaramillo PMD, Silveira MHL, Andreaus J, Couto $F A$, et al. The potential of agro-industrial residues for production of holocellulase from filamentous fungi. Intern Biodeterior Biodegrad. 2010;64(1):20-6.

93. Embrapa. Embrapa Soja. Londrina-PR: Empressa brasileira de pesquisa agropecuária- Embrapa. 2016 [cited 20/01/2016]. Disponível em: www.embrapa.br/web/portal/soja/cultivos/soja1/dados-economicos.

94. Bowles S, Demiate IM. Caracterização físico-química de okara e aplicação em pães do tipo francês. CiêncTecnol Alim. 2006;26(3):652-9.

95. Jackson C-J, Dini J, Lavandier C, Rupasinghe H, Faulkner H, Poysa V, et al. Effects of processing on the content and composition of isoflavones during manufacturing of soy beverage and tofu. Process Biochem. 2002;37(10):1117-23.

96. O'Toole DK. Characteristics and use of okara, the soybean residue from soy milk production a review. J Agric F Chem. 1999;47(2):363-71.

97. Pessoa A, Kilikian B. Purificação de produtos biotecnológicos;2005.1ed. Barueri-SP:Manolle;2005.

98. Vitolo M, Pessoa A. Biotecnologia farmacêutica:aspectos sobre aplicação industrial. 1ed.São Paulo-SP: Blucher;2015.

99. Gerberding SJ, Byers C. Preparative ion-exchange chromatography of proteins from dairy whey. JChromatograph. 1998;808(1):141-51.

100. Levison PR. Large-scale ion-exchange column chromatography of proteins: Comparison of different formats. J Chromatogr. 20036 (25):17-33. 
101. Isobe K, Takahashi N, Chiba S, Yamashita M, Koyama T. Acidophilic fungus, Teratosphaeria acidotherma AIU BGA-1, produces multiple forms of intracellular $\beta$ galactosidase. J Biosc Bioengineer. 2013 8;116(2):171-4.

102. Widmer F, Leuba JL. $\beta$-Galactosidase from Aspergillus niger. European J Biochem. 1979;100(2):559-67.

103. Siqueira FG, de Siqueira AG, de Siqueira EG, Carvalho MA, Peretti BMP, Jaramillo PMD, et al. Evaluation of holocellulase production by plant-degrading fungi grown on agro-industrial residues. Biodegradation. 2010;21(5):815-24.

104. Bradford MM. A rapid and sensitive method for the quantitation of microgram quantities of protein utilizing the principle of protein-dye binding. Anal Biochem $1976 ; 72(1): 248-54$.

105. Laemmli UK. Cleavage of structural proteins during the assembly of the head of bacteriophage T4. nature. 1970;227(5259):680-5.

106. Leatherbarrow RJ. Enzfitter Manual a Non-Linear Curve Fitting. Program for Windows Biosoft : London: 1999;1-104.

107. Miller GL. Use of dinitrosalicylic acid reagent for determination of reducing sugar. Anal Chemist. 1959;31(3):426-8.

108. Silveira CB. Digestibilidade das proteínas do soro do leite mediante ensaio in vitro [Mestrado]. Araraquara - SP: Universidade Estadual Paulista. ; 2010.

109. BRASIL. Farmacopeia Brasileira. $5^{\underline{a}}$ ed. Brasília: Agência Nacional de Vigilância Sanitária - Anvisa. 2010. p. 458.

110. Posch AE, Herwig C, Spadiut O. Science-based bioprocess design for filamentous fungi. Trends Biotechnol. 2013 Jan;31(1):37-44.

111. Colen G. Isolamento e Seleção de fungos Filamentosos produtores de lipase. Belo Horizonte: Universidade Federal de Minas Gerais; 2006. 
112. Slivisnki CT. Produção, purificação parcial e caracterização bioquímica de glucoamilase de Aspergillus niger obtido por fermentação em estado sólido. Ponta Grossa: Universidade Estadual de Ponta Grossa; 2007.

113. Papagianni M. Fungal morphology and metabolite production in submerged mycelial processes. Biotechnol Advanc. 2004;22(3):189-259.

114. Andrades Dd. Hidrolases de fungos isolados da Mata Atlantica cultivados em resíduos agroindustriais: Produção, purificação e caracterização enzimática. Paraná: Universidade Estadual do Oeste do Paraná.; 2014.

115. Braga ARC, Gomes PA, Kalil SJ. Formulation of culture medium with agroindustrial waste for $\beta$-galactosidase production from Kluyveromyces marxianus ATCC 16045. Food Bioproc Tech. 2012;5(5):1653-63.

116. Tavares VB, Sivieri K, Ceron CR, Silva Rd, Trabuco E, Lombardi FR, et al. Utilização do resíduo líquido de indústria de processamento de suco de laranja como meio de cultura de Penicillium Citrinum: depuração biológica do resíduo e produção de enzima. Quim Nova. 1998;21(6):722-5.

117. Arantes $\mathrm{V}$, Milagres $\mathrm{AM}$. Relevância de compostos de baixa massa molar produzidos por fungos e envolvidos na biodegradação da madeira. Quim Nova. 2009;32(6):1586-95.

118. Cavalcanti A, Couri S, Silva L, Melo V. Avaliação da Capacidade Produtora de Fitase de Diferentes Linhagens de Fungos Filamentosos. 2014:547-8.

119. Souza PM. Produção de proteases porfungos filamentosos isolado do cerrado centro-oeste brasileiro [Doutorado]. São Paulo: Universidade de São Paulo -USP; 2015.

120. Isobe K, Yamashita M, Chiba S, Takahashi N, Koyama T. Characterization of new $\beta$-galactosidase from acidophilic fungus, Teratosphaeria acidotherma AIU BGA1. J Biosc Bioeng 2013 9;116(3):293-7.

121. Teófilo RF, Ferreira MM. Quimiometria II: planilhas eletrônicas para cálculos de planejamentos experimentais, um tutorial. Quím. Nova. 2006;29(2):338. 
122. Rahman RNZA, Geok LP, Basri M, Salleh AB. Physical factors affecting the production of organic solvent-tolerant protease by Pseudomonas aeruginosa strain K. Biores Technol. 2005;96(4):429-36.

123. Oliveira AN, Flor NS, Oliveira LA. Influência do $\mathrm{pH}$ e temperatura sobre a atividade amilolítica de rizóbios isolados de solos da Amazônia. Acta Amazonica. 2010:401-4.

124. Sudharhsan S, Senthilkumar S, Ranjith K. Physical and nutritional factors affecting the production of amylase from species of bacillus isolated from spoiled food waste. African J Biotechnol. 2007;6(4).

125. Calado V, Montgomery D. Planejamento de Experimentos usando o Statistica.Rio de Janeiro:E-papers; 2003.

126. Lima CAA, Lima EDPA, Gerald LTS. Obtenção e caracterização da enzima $\beta$ galactosidase de origem fungica. Rev Agropecuária técnica. 1982;3(2):73-80.

127. Adalberto PR. Produção, isolamento e caracterização de'beta'-galactosidades de Trichoderma reesei: interação de íons metálicos na atividade enzimática [Doutorado]. Araraquara: Universidade Estadual Paulista-UNESP; 2005.

128. Shaikh SA, Khire JM, Khan Ml. Characterization of a thermostable extracellular $\beta$-galactosidase from a thermophilic fungus Rhizomucor sp. Biochimica et Biophysica Acta (BBA) - General Subjects. 1999;1472(1-2):314-22.

129. Wheatley RW, Juers DH, Lev BB, Huber RE, Noskov SY. Elucidating factors important for monovalent cation selectivity in enzymes: $\mathrm{E}$. coli $\beta$-galactosidase as a model. Physical Chem Chemical Physics. 2015;17(16):10899-909.

130. O'Connell S, Walsh G. A novel acid-stable, acid-active beta-galactosidase potentially suited to the alleviation of lactose intolerance. Applied microbiology and biotechnology. 2010;86(2):517-24.

131. Silva Campos TCÁ, D’Almeida WK, Alegro LCA, Roig SM, Suguimoto HH. Utilização da $\beta$-galactosidase na Hidrólise da Lactose do Leite em Baixa Temperatura. UNOPAR Científica Ciências Biológicas e da Saúde. 2014;11(4). 
132. Klein M P EVJ, Revillion P P. Use of -galactosidase in milk sweet: avoiding lactose crystallization. Ciênc Agrotec. 2010;34(6). 